Portland State University

PDXScholar

Summer 8-10-2017

\title{
Analyzing the Online Environment: How are More Effective Teachers Spending Their Time?
}

Scott Davis Barrentine

Portland State University

Follow this and additional works at: https://pdxscholar.library.pdx.edu/open_access_etds

Part of the Online and Distance Education Commons, and the Science and Mathematics Education Commons

Let us know how access to this document benefits you.

\section{Recommended Citation}

Barrentine, Scott Davis, "Analyzing the Online Environment: How are More Effective Teachers Spending Their Time?" (2017). Dissertations and Theses. Paper 3833.

https://doi.org/10.15760/etd. 5727

This Thesis is brought to you for free and open access. It has been accepted for inclusion in Dissertations and Theses by an authorized administrator of PDXScholar. Please contact us if we can make this document more accessible: pdxscholar@pdx.edu. 
Analyzing the Online Environment:

How Are More Effective Teachers Spending Their Time?

by

Scott Davis Barrentine

A thesis submitted in partial fulfillment of the requirements for the degree of

Master of Science in Teaching

in

General Science

Thesis Committee:

William Becker, Chair

Cary Sneider

Stephanie Wagner

Portland State University

2017 


\begin{abstract}
Teaching at an online school is so different from classroom teaching that traditional training includes few of the skills necessary to be a successful online teacher. New teachers to an online environment face a steep learning curve in how they'll use the instructional technology, prioritize their time, and establish relationships with their students. The literature has advice for these teachers about effective online practices, but there has been little research to establish which strategies are most effective in motivating students. This pre-experimental study, conducted at an online 6th-12th grade hybrid school, investigated the practices used more often by the most effective teachers. Teacher effectiveness was measured by the number of assignments their students had not completed on time. Recognizing that the effectiveness of different practices will vary from student to student, the research analysis included two covariates, measured by surveys: the academic identity and motivational resilience of the students, and the students' self-reported preferences for motivational strategies. More effective teachers were found to make videos more frequently, both of the teacher for motivational purposes and recorded by the teacher to help students move through the curriculum. Quick grading turnaround and updating a blog were also more common with all effective teachers. Distinct differences between middle and high school students came out during data analysis, which then became a major point of study: according to the data, more effective middle school teachers emphasized individual contact with students, but the less effective high school teachers spent more time on individualized contact. The surveys used in this study could be modified and implemented at any online school to help teachers discover and then prioritize the most effective strategies for keeping students engaged.
\end{abstract}




\section{Acknowledgements}

This thesis would have been impossible without the dedicated work of Dr. Cary Sneider, Stephanie Wagner, and Bill Becker in the MST Program at PSU. There would be no thesis at all without the support of the West Excellence School, its Principal/CEO, and the wonderful teachers at WES who allowed themselves to be studied. The school and its teachers' names have been replaced in this thesis in the interests of anonymity. 


\section{Table of Contents}

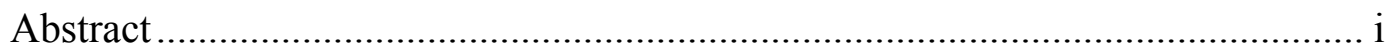

Acknowledgements ...................................................................................... ii

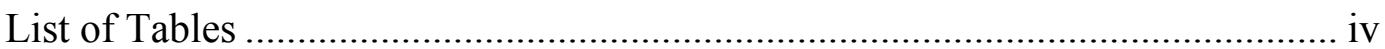

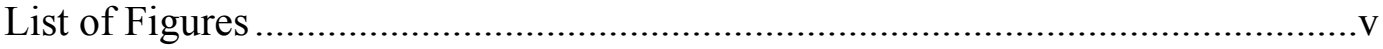

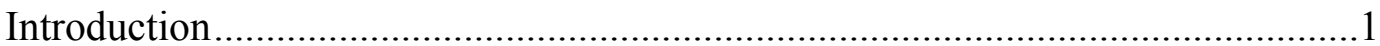

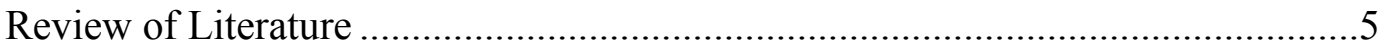

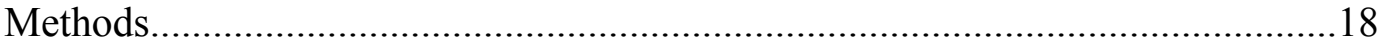

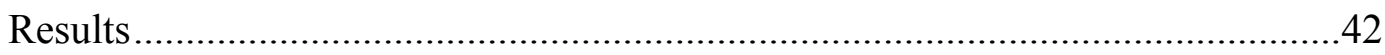

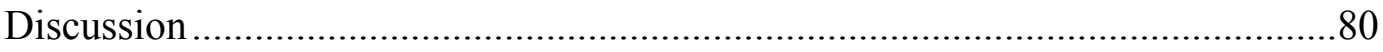

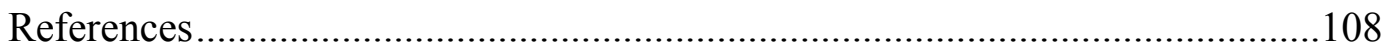

Appendices

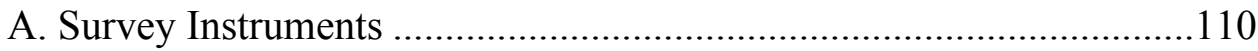

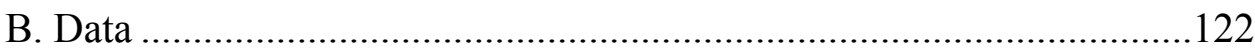

C. Human Subjects Approval .................................................................152 


\section{List of Tables}

Table 1. Scoring Grading and Response Time Answers in Teacher Survey ........34

Table 2. Standard Deviations of each Teacher Practice.....................................44

Table 3. High School Teacher Rankings.......................................................46

Table 4. Middle School Teacher Rankings .......................................................48

Tables 5-13. Individual Teacher Subject Breakdowns................................ 50-64

Table 14. Difference in Practice Frequency between top and bottom teachers ....66

Table 15. Math Affective Variable Gap Analysis...............................................71

Table 17. Science Affective Variable Gap Analysis ..........................................72

Table 18. Technology Affective Variable Gap Analysis ..................................74 


\section{List of Figures}

Figure 1. The Florida Virtual Schools' curriculum in Brainhoney …..................23

Figs. 2-10 Teacher-specific Teacher-action Distributions............................ 49-61

Figure 21. Math Affective Variable vs. Assignments Behind .............................70

Figure 12. Science Affective Variable vs. Assignments Behind .........................70

Figure 13. Technology Affective Variable vs. Assignments Behind ...................73 


\section{Introduction}

For the 2013-14 and 2014-15 school years, I was an instructor at the West Excellence School (WES), which used an online curriculum for 6th-12th graders. We had a building with classroom facilities in Gresham, Oregon, so that students could come in for help in a hybridized environment, but students were rarely required to attend physical school. Students had to self-regulate and complete roughly 15-20 assignments per week for their (usually) six classes using curriculum purchased from Florida Virtual Schools (FLVS). As a new online teacher, I did not know how to prioritize my time; my teacher training did not include any elements specific to working in an online environment. My primary day-to-day responsibilities consisted of grading and answering emails, but to address motivation I needed to do a lot more, so I decided to study how teachers were spending their time and attempt to measure the effectiveness of those strategies.

Motivation is important to the success of all learners, but it is absolutely crucial for middle and high schoolers attending an online school (Azaiza 2011). Students have to be motivated enough to work from home, with no exact schedule, on lessons and projects that didn't necessarily interest them. Online courses require more resilience, selfdiscipline, and initiative than traditional classrooms (Dennis et al. 2007). The goal of this study is to build a ranked list of motivational strategies so that online teachers can better prioritize their time when conducting an online course.

"Of all the situational variables affecting student motivation, perhaps none exerts such a strong and pervasive effect as faculty attitudes and behavior. Instructional communication such as giving feedback on performance constitutes a prime opportunity 
either to enhance motivation or decimate it" (Dennis et al. 2007 pg. 39). Teacher practices have to be the basis for teacher-student relationships in an online setting, because there's no idle time or face-to-face interactions that ease the establishment of relationships, so online teachers have to find other ways to get closer to their students socially and psychologically. "Verbal interaction between instructors and students is vital. Instructors in online courses, more so than in face-to-face courses, must seek evidence of students' feelings and motivation, especially their reactions to the written word, which is devoid of vocal tone" (Dennis et al. pg. 40).

Online teachers employ a variety of strategies to insert "teacher presence" into their courses, like creating videos, updating a blog, or re-writing curriculum, but it's hard to know how effective these practices are without research. If some teachers are getting more success out of their students, what are they doing differently? Motivation is important because it leads to engagement, and engagement in an online course is necessary for students to complete assignments (Wang et al. 2007) and ultimately earn credit for the courses necessary to graduate. My initial research question was: What strategies are most effective in motivating students to complete assignments in an online environment? My data answered a different set of questions, however:

1) How do teachers at an online school allocate their instructional time?

2) What instructional strategies are more commonly used by effective teachers at an online school?

3) How do students' subject-specific affective variables correlate with their success in math and science courses?

4) What are the differences between middle and high school online students regarding the answers to research questions two and three? 
First I surveyed teachers about how frequently they enacted a variety of instructional practices for my primary independent variable. Engagement was measured by numerical data on how many assignments behind schedule students were for each teacher, the dependent variable. Primarily, I hoped to find a clear relationship between certain practices and student success, so that those practices could be prioritized by online teachers. The closest I could come to that goal was the average difference in frequency for each practice between the top four and bottom four teachers, which gave me a list of strategies ranked by how much more frequently the more effective teachers did them.

To study the student-side of online school, I surveyed students on their academic identity (self-confidence), motivational resilience (ability to persevere through intellectual obstacles), and their opinion of how motivational they find different practices. After finding some distinct differences between Middle and High School students, I analyzed them separately, providing some interesting disparities. I also investigated the relationships between three students and their math and science teachers, and asked the students what practices they find most motivational from those teachers.

My quantitative data was gathered in three surveys: one for teachers, asking about their instructional practices, and two for students, one asking about their academic identity and motivational resilience, and the other asking how motivational they find specific strategies and their relationship with the teacher. The school also pulled engagement data multiple times throughout the year, so I was able to analyze the entire student body in order to rank the teachers from most to least effective, based on what 
percentage of their students were more than $20 \%$ behind pace and thus unlikely to finish the course.

The school was still in growth mode during my research period: the curriculum had changed repeatedly (this was the first year that the curriculum mirrored the year previous), overall policies were fluid and teacher-centered, and I felt a lot of frustration from everyone at the school that what we were doing was not working. Expected failure rate hovered anecdotally around $50 \%$ (confirmed by this research), mostly due to lack of engagement; actually attempting all the assignments and still failing was extremely rare. Frustration with the seeming futility of many of our teaching strategies led me to this research, so I could find what strategies actually worked. I hoped to find a few practices that were used more often by the most effective teachers as well as improve the system for gathering this information so that other online school leaders could investigate which practices were most effective for their student populations. 


\section{Literature Review}

This Literature Review is divided into four sections, addressing the importance of motivation (particularly online), analyzing previous studies on online students and instructional and motivational strategies, measurement issues that have influenced the method used in this study, and post-data analysis literature review.

\section{Importance of Motivation}

In "Learners' motivation in a distance education environment," Khitam Azaiza (2011) presents a review of the literature, indicating that motivation is especially important in the online environment. Azaiza covers the ARCS model from the Learning Theories Knowledgebase and relates those elements (Attention, Relevance, Confidence, and Satisfaction) to how they can be accomplished online. Most important is offering a range of delivery tools so that diverse students can all be motivated. Relationships with

other students and with the teacher are also significant motivational factors, and an online instructor must use varied strategies to strengthen those relationships. Azaiza emphasizes the importance of timely feedback and question responses to keep students engaged and suggests that staff be well trained in a variety of tools. Ultimately, "self-motivation, learner-to-learner interaction, instructor-to-learner interaction, content, and institutional support are the major motivational factors that definitely have an effect on students' performance and persistence in distance education" (Azaiza 2011, pg. 27).

Wang, Shannon, and Ross (2007) ran the numbers on 256 college student surveys to try and find any connections or relationships they could between students' characteristics, ability to self-regulate, their self-efficacy with technology, and the course 
outcomes (passing the class or getting better grades). Their review of the literature indicated many statistically significant relationships between these variables, but none of the previous studies tried to compare all of them at once, so the authors utilized a multivariate approach. They concluded that the highest indicator of course success was participation in previous online courses, because those students generally had higher motivation, technology self-efficacy, and used learning strategies more effectively. Students who used effective learning strategies also had higher motivation, which resulted in more course satisfaction and technology self-efficacy, which tended to lead to higher grades. The authors did not find any significance in gender or level of education. They did find that motivation directly connected to higher course satisfaction and higher technology self-efficacy, and both in turn increased the final grade. Technology selfefficacy is so important that the researchers suggest that instructors should focus on it specifically by giving a course-specific orientation that also teaches general Internet skills.

Both of these studies conclude that motivation is critical to success in any environment, but most especially online. Students are motivated by relationships with their teachers; in distance education, teachers must use varied strategies to connect with their students because relationships can't occur naturally like they might in a face-to-face environment. My study hopes to connect more dots around what actually motivates students, with the 'assignments behind' engagement numbers representing how motivated students were to complete assignments. 


\section{Online Teaching Strategies}

The study "Motivation and Learning Characteristics Affecting Online Learning and Learning Application," by Doo H. Lim and Hyunjoong Kim (2003), sought to find the most important factors in motivation of online students. Using their review of existing theories, Lim and Kim focused their study of 77 undergraduate students around 5 variables: course relevancy, course interest, reinforcement, affect/emotion, and selfefficacy. Every category except, oddly, course interest, had a significant effect on higher learning objectives. They also used some personal characteristics data and found that being female or a full-time student was correlated with higher success in online environments.

The authors concluded that effective online courses should include real-world application problems to engage students in applied learning, since course relevancy was the most important motivational factor. They also recommended collaborative opportunities for students to work together on authentic problems. Reinforcement and self-efficacy were the next most important factors, but the student-teacher relationship can be tricky to establish in an online environment. Kim and Lim suggested that improving the immediacy of teacher feedback and support is an important motivating factor.

The study "Reasons for student dropout in an online course in a rural $\mathrm{K}-12$ setting" (de la Varre et al. 2014) uses qualitative data from both students and teachers in an attempt to find common reasons that students drop out of an online course. The data came from emailed surveys to students who had decided to drop out of a specific 
challenging AP course and surveys of their facilitators, who were working with the students in the school. The teachers, who were located in a different state, were not interviewed, as they lacked a personal connection with the students - which might be part of the reason for the high dropout rate of online courses. Facilitators and students gave similar reasons for why the students were dropping out, but when they disagreed, it was often when facilitators said the students were unmotivated or even lazy. The problems listed almost all fell into one of these categories:

- Overloaded schedule

- Difficulty with the technology or format of online courses

- Motivation

- Lack of connection and communication with the teacher

- Impersonal nature

- Parental influences

Most students listed multiple reasons for dropping out, which means there's plenty that online learning environments can do to improve the experience for students. The researchers suggest a number of implications from the data, saying that students should be:

- Advised by previous teachers if the online environment is right for them

- Given strong front-loaded orientation for the online environment, detailing the expectations and technology necessary for the course

- Supported by trained parents and facilitators, particularly with time management skills and motivation

- Given a dedicated place and time to work

- Given "realistic expectations for student-teacher engagement and responsiveness" (de la Varre et al. 2014 pg. 14) 
For my research question, the most relevant parts of the study are the factors related to motivation and teaching strategies: "teacher immediacy" involved answering questions and grading assignments in a timely manner, neither of which were quick enough for some of the students; other students just couldn't handle the lack of face-toface communication. Facilitators agreed, saying that the teacher feedback was slow, overly brief, and impersonal, and they say the failure in communication was the main reason some students dropped the course.

In "Promoting Academic Motivation and Self-Regulation: Practical Guidelines for Online Instructors," Anthony Artino and Andri Ioannou (2008) present a review of existing literature, organized into actionable guidelines for teachers to follow when creating and conducting online courses. Students' self-efficacy and self-regulation are paramount to success, especially online, so teachers should use prompt, adaptive feedback to give individualized responses that build the student's confidence. Assignments should also be relevant, so using more authentic, real-world problems (that aren't too complex) can really motivate students because they see why the answer matters. Online discussions should be moderated and modeled by the teacher to promote critical-thinking skills as students are encouraged to respond to each other's comments and learn from the discussion. Finally, teachers should encourage collaboration and peerreview amongst students. Beyond just placing them into groups, teachers must encourage positive behaviors and attempt to motivate students who aren't actively participating. 
Meredith DiPietro et al. (2008) noticed a dearth of research into best practices in an online environment and decided to investigate. The literature is full of online practices adapted from traditional face-to-face strategies, but lacks the unique practices that online teachers are actively employing and their perception of those practices. The researchers also noted that teachers are not being trained for the online environment, so they interviewed 16 highly qualified Michigan Virtual School teachers in a variety of disciplines about their online practices. DiPietro et al. used a simple 7-question interview semi-structure that allowed for follow-up questions and coded the responses. The responses were consistent enough to present 12 general characteristics and 25 strategies that all the teachers mentioned, which serves as a wonderful starting point for a list of "best online practices." Characteristics of teachers that were labelled as motivational include going the extra mile, establishing presence in the course, and forming relationships with the students. Strategies that were described as motivational included: clearly organizing the course, including deadlines for assignments, varying instruction for different learning styles, using varied strategies to connect with students including discussing non-content topics, providing diverse lines of communication, and being prompt with feedback. The researchers reiterated the necessity of more research into best practices, especially concerning unique things like online classroom management and hybridized environments.

The article "Best Practices in Cyberspace: Motivating the Online Learner," by Toni Bellon and Richard Oates (2002), is a report from new online teachers about their survey research into connecting students' personality types with the practices in an online 
course that most motivate students. The authors were coming from years of experience in traditional classes and wanted to study the most effective practices for motivating students in an online environment, where many of the personal interactions between teachers and students that take place in classrooms every day seem impossible.

Bellon and Oates' main tool for data gathering was student surveys, asking 31 students who took their online course as part of their master's program to rank different practices from 1-5 based on how motivating they found them. Those answers were compared to results from an online Jung Typology Test used to determine personality type. The comparisons of most motivating practices to students' personalities was mostly useful to the idea that various practices should be used; as in a traditional classroom, varied instruction is key to reaching all students.

Results from the student surveys allowed the authors to roughly rank the following practices, ordered from most to least motivating:

Highly Motivating:

1. Emails from the teacher

2. Posting to a bulletin board and responding to others' posts (note: introverts scored this much lower)

3. Target due dates that also had flexibility

4. Teacher-provided Internet links or lectures

5. Beginning each chapter with summaries of the assignments

6. Non-text visual information

Not very motivating:

7. Emails from other students

8. Other students' bulletin board postings or responses

9. Assigned textbook readings 
The authors found a few interesting personality-specific tendencies, concluding that a student's personality can determine how much he or she retains motivation throughout the course. Overall they decided that interaction was key to student success, while readings from the textbook were almost universally disliked.

In "The Little Engine That Could - How to Start the Motor? Motivating the Online Student," Dennis, Bunkowski, and Eskey (2007) analyzed literature on motivation and applied it to the online environment after studying over 200 instructors and their courses. Their literature review emphasizes the importance of motivation, particularly in online courses, and cites teacher behavior as a primary source of motivation for online students. Teachers can motivate students with clearly stated learning expectations and well-crafted communication and feedback on completed assignments. The authors warn that poorly-chosen tone can demotivate students and suggest that vocal connections with students can help teachers understand how to best phrase their communications to establish a relationship and enhance the self-efficacy of students. Teacher feedback should be constructed thoughtfully to come across as constructive and respectful so that students don't feel threatened.

Dennis et al.'s study established "five key dimensions of effectiveness: interaction, individual attention, timeliness of information and response, information transmission, and accessibility and skill at moderating the flow of learning" (Dennis et al. 2007 pg. 40). They suggest that topics should be relevant to students' lives and use current information rather than textbooks whenever possible, which can be made easier by assigning work that requires research. The authors provide an extensive chart that lists 
solid teacher strategies, organized by when they can be enacted, which comprises the bulk of their study's conclusions. The relative effectiveness of these strategies was not investigated.

Dennis et al. also analyzed the motivation of teachers who chose to be online instructors and the barriers that can frustrate them, citing sources that agree with the importance of teachers themselves being properly motivated. Crucially, instructors who move to online schools have to adjust to their changing role from 'teacher' (usually meaning provider of information) to facilitator or 'learning catalyst' (Dennis et al. 2007, pg. 43). Dennis et al. also outline suggestions to help faculty who are transitioning to online school, with cited sources that can help further. The authors conclude that we need to continue studying online students and their "unique challenges." Their most solid motivators "include...timely course material, information sharing between faculty and students, and mediation and moderation by involved instructors" (pg. 43).

The title of the paper "Research on the Use of Khan Academy in Schools," written primarily by Robert Murphy with SRI Education with funding from the Bill and Melinda Gates Foundation (2014), provides a succinct summary of its contents. The researchers conducted an implementation study of twenty schools and more than seventy teachers to see how they're using Khan Academy, which is a free, online tutorial website that offers video tutorials, practice problem sets, and interactive step-by-step help on a variety of topics, mostly math-based. While they couldn't fully evaluate Khan Academy's impact on learning, they still drew conclusions based on how it was being used and comparative test scores whenever that data was available. Additionally, Khan 
Academy used this research to improve their website significantly, and those changes were logged in this paper.

Use of Khan Academy varied wildly between schools, because of both its flexibility and the lack of requirements and organization along grade-level categories (later fixed by Khan Academy). Khan Academy's videos and practice problems can be used as practice, intervention, or enrichment, and the data it provides (now in email form directly to the teacher) increases accountability for students and connects success or failure directly with the amount the student practiced and learned. Many of the teachers used Khan Academy in the classroom alongside more traditional teaching methods, like the school that couldn't afford enough laptops, so Khan Academy time was just one of the stations in their daily math routine. This paper went in depth on three of the sites studied, each of which had distinct qualities and ways of implementing the Khan Academy resources.

The first site (Site 2) described by Murphy et al (2014) was the most interesting to me because it involved two charter schools that were attempting true educational revolution by designing their entire school days around self-paced learning, which gives students more responsibility much like an online school would. Site 2's math teachers served as facilitators in very large, open classrooms for daily time blocks in which students were expected to self-direct their work. Students were given 'playlists' to guide them, but no specific material to study was required; after they'd researched the topic and felt comfortable with it, they could take the school-created test and move on if they passed. This organization follows more of a proficiency model, allowing students to 
move on if they've mastered a topic or remediate further if they need more help. With this extra responsibility on the students' shoulders, "the schools learned that some students needed additional support to do this kind of independent work" (Murphy et al, 2014, pg. 6). Site 2 has increased teacher-student face-to-face time for these students and improved the progress monitoring so that teachers notice more quickly when a student is lagging behind.

The other schools described by Murphy et al were more traditional, but they were still using the online support to build "students' self-discipline, sense of individual responsibility, and overall work ethic" (Murphy et al, 2014, pg. 7). One site's teachers said that immediate feedback was the most appreciated part of the Khan Academy part of classes, because students could immediately start remediating their mistakes. Overall, support for Khan Academy sessions was very high among both teachers and students; students felt like they had more independence, and in some schools showed measurable improvement. $89 \%$ of the teachers plan to use Khan Academy again because it helps them support students more effectively and they can see that the sessions have been working, both in the Khan Academy reports and other class activities. Teachers also liked the modular nature of the curriculum, how much it helped them differentiate, and they again emphasized how nice the rapid feedback was for students.

Khan Academy made a number of changes based on this research and the website now contains grade-level information and missions, along with goal-setting features and greater alignment to specific content areas used in schools. In their conclusion, Murphy et al. mention how much "teachers like having a source of extensive, curated digital 
content" (pg. 16) but the flexibility to assign it independently. They also say that most students are not ready to be fully independent learners, so frontloaded training and orientation are necessary for success.

These research papers indicate that teacher presence in an online course is most important to student success, but there are many ways to insert presence. In online teaching, the role of the teacher is closer to facilitator or motivator, and teacher language should reinforce that role by maintaining encouraging language. Effective practices include: grading and responding promptly, forming relationships with students, use of real-world problems, and providing support in a variety of ways. This research paper will investigate the specific practices in use by the teachers at WES and compare the frequency of practices between more effective teachers and their less effective colleagues.

\section{Measurement Devices}

The primary purpose of the paper, "A common measurement system for k-12 STEM education: adopting an educational evaluation methodology that elevates theoretical foundations and systems thinking" by Emily Saxton and others (2014), is to convince educators and administrators to adopt a set of common measurements, so that data can be used to improve instructional practices. By focusing mostly on surveys of students and teachers, the specific qualities that most improve achievement (such as selfefficacy and higher order thinking skills) can be measured, rather than simply measuring what students do and do not know. Student achievement should not be the only test for 
teachers; specific surveys have been designed or adopted to "test" the teachers' abilities directly.

Saxton et al. argue that higher-level educational institutions and employers would rather know what students can DO to apply their knowledge and solve complex problems, so the "tests" need to include performance assessments to measure skills that cannot be measured by multiple choice alone. The authors say that many educators underestimate their students, which keeps them from challenging students on higherorder cognitive skills.

If these common measures are widely adopted, the specific qualities of good schools can be correlated to student achievement, so that all educators can use the data to actually drive instructional improvements. Past measuring systems, usually standardized tests, create an environment of knowledge acquisition and don't test other factors recommended by the paper, like higher-order thinking skills. Not only will these new common measures provide valuable data on specific areas of needed improvement in proper and effective STEM education, but they will also raise the expectations for students, which should drive gains in the higher-order cognitive skills and application of knowledge that are far more important for continued education and life in the real world. For my study, I adapted both the Affective Variable and Student-Teacher Relationship surveys from this paper so my independent variables would be grounded in peer-reviewed surveys. The majority of my adjustments involved replacing classroomspecific language to make the survey fit the online environment better. 


\section{Methods}

\section{Overview}

This was a pre-experimental mixed-methods research study that took place at the West Excellence School (WES) in Gresham, Oregon. My original research question sought the most effective instructional strategies for motivating online students, but my results ended up answering the following questions:

1) How do teachers at an online school allocate their instructional time?

2) What instructional strategies are more commonly used by effective teachers at an online school?

3) How do students' subject-specific affective variables correlate with their success in math and science courses?

4) What are the differences between middle and high school students regarding the answers to research questions two and three?

The independent variable of the study was the variety of strategies used by the teachers, as measured by a teacher survey. The dependent variable was the average number of assignments behind schedule that teacher's students were, which is correlated with engagement and students' ability to finish the course on time. A co-variate was the students' self-reported affective variable, which describes their attitudes toward Math, Science, and Technology.

Research question one was answered by a survey of the teachers at WES that asked them how often they used a variety of instructional practices. To answer research question two, I deeply analyzed that teacher data to determine which practices were most common with the more effective teachers at WES. Research questions three and four were answered by profiles of the 23 students who participated in the affective variable 
survey, and a further analysis of three students who answered the survey about their relationship with their math and science teachers and what teacher strategies they found motivational. Recognizing that the same strategies may not be effective for all students, this study also serves as a methodology that other online schools could use to investigate their own populations.

\section{Timeline Diagram:}

I surveyed teachers on their practices first, then WES announcement procedures (discussed below) were used to send students the assent, consent, and affective variable surveys. One month later, I sent another announcement asking for more students to participate and I included a link to the second survey, which Melissa Potter also sent directly to the students who participated in the first survey.

\begin{tabular}{|l|l|l|l|l|l|}
\hline \multicolumn{2}{|l|}{ April } & April & May & May & June \\
\hline N & O $_{\text {TP }}$ & X O $_{\text {PC }} \mathbf{O}_{\text {SA }}$ & X O $_{\text {STP }}$ & X & X O O \\
\hline
\end{tabular}

$\mathbf{X}=$ Ongoing Treatments

$\mathbf{O}_{\mathbf{T P}}=$ Teacher Practices Survey

$\mathbf{O}_{\mathbf{S A}}=$ Student Affective Survey (with assent)

$\mathbf{O}_{\mathbf{P C}}=$ Parental Consent Form

$\mathbf{O}_{\text {STP }}=$ Student Survey of Teacher Practices

$\mathbf{O}_{\mathbf{S P}}=$ Collection of Students' Pacing Data (available via school-wide analysis already collected by the school's IT person with six weeks and one week left in each semester.)

\section{Participants}

I studied the teachers at the West Excellence School (WES) using the Teacher Survey of Practices (Appendix A-1) during my second year there as a half-time science 
teacher. The eight other teachers I studied, Diphily, Howell, Reed, Cook, Everett, Corona, Goudy, and Martin (all pseudonyms to maintain anonymity), came to the school at a variety of times with quite different experience levels. Our typical work week started with a Monday morning all-staff meeting, and generally teachers spent an additional two or three days at school, depending on their schedule, and worked the other days online from home.

The student subjects for this study were 23 middle and high school students at WES. Students at WES chose online school for various reasons. WES is a public charter school, so any student in the Gresham-Barlow district could choose it and could not be rejected or cut from the program unless they failed the attendance requirement, which was to $\log$ in once every ten days. WES tried to implement a higher minimum attendance requirement so that we could move students who weren't engaging back to traditional school (these students were essentially not attending school at all, but legally weren't truant), but we discovered that enforcing those higher standards would have left the school without a sufficient budget for staff.

Many of our students had already been unsuccessful in traditional environments and this alternative school offered another chance at earning credits. Because I ran the "Surf School" introductory class, I saw every new student to the school for over a year, and I sometimes asked why they chose online school; I stopped asking because of how personal their answers tended to be, usually related to anxiety or other tough social issues. Many students were at online school because they had already failed out of (sometimes many) other schools. Unfortunately, a majority of students who came to us 
behind in credits continued to be unsuccessful, but the success stories kept us from giving up.

WES's demographics in the 2015-16 school year were 72\% white, 18\% Hispanic; all other racial categories were less than 3\% represented (ODE Report Card Download, 2016, pg. 1). Gresham has a significant Russian-Ukrainian population, so we had a number of those students and they generally did very well, as school tended to be a priority for them and their involved families. Some students were at online school specifically because of a social problem in traditional schools, like anxiety or because they experienced bullying, and we also had a number of transgender students.

Anecdotally, students who chose online school primarily for social reasons tended to thrive in this environment, along with high-performing students who wanted to finish high school early. We also had students who participated in extreme sports like skiing, windsurfing, and skateboarding at a level that prevented them from attending traditional school. Overall, approximately $50 \%$ of our students were not earning sufficient credits during their time with us, so improving student success was the primary goal of our organization. WES's graduation rates were lower than similar schools across the board; in the 2015-2016 school year, only 56.7\% of our freshmen were on track to graduate and our graduation rate was only $39.6 \%$ the year before, compared to a like-school average of $43.4 \%$. The drop-out rate was $20.6 \%$, which looks terrible against the $4.3 \%$ Oregon-wide average, but like-schools averaged a $19.1 \%$ dropout rate so we were comparable there (ODE Report Card Download, 2016, pg. 2). 
For this study, we sent information and links to the surveys using WES's traditional announcement platforms and analyzed the data of the 23 students who both answered the initial survey (including assent) and whose parents filled out the consent form. Only three students from that group also answered the second survey, so I analyzed that data from a 'case study' perspective. In order to rank the teachers by effectiveness, I was able to use the entire school's 'assignments behind' data because it was gathered by the school already, so it didn't require assent/consent.

\section{Treatment}

Students at online school must log-in regularly and complete assignments based on information from the curriculum and the internet; teachers rarely instructed or lectured in a traditional way. Most of the curriculum we used at WES was purchased from the Florida Virtual School (FLVS), which has been developing curriculum for online learning for over 20 years. FLVS curricula was formatted similarly across all subject areas: students read information, then completed either a quiz or assignment, which we asked students to turn in using a link to their Google Doc. Units began with information delivery, usually presented using slightly-interactive reading that required a few button clicks to expand on certain topics or go on to the next page of information. Embedded games were also common and provided crucial ungraded practice opportunities like matching vocabulary to definitions or re-ordering a list in chronological order. Quizzes and tests were mostly multiple-choice so grading was sometimes instantaneous, but they often had a few short answer questions that had to be graded by the teacher, delaying results for the student. Unfortunately, because of FLVS' common usage across America, 
most of the questions could be copy/pasted into Google to find direct answers on Yahoo Answers and other similar "study help" sites. Teachers could edit test questions, which was nice, but the rest of the curriculum was "locked in" - we couldn't change any information inside the information delivery areas or assigned projects/papers. We could put other items in between curriculum areas (like I did with "Resume Help" in Figure 1), but they would never be as graphically interesting as the curriculum itself, which is open in Figure 1. There were surprisingly few videos in the FLVS classes, but teachers sometimes inserted video explanations of parts of the curriculum in a similar spot to "Resume Help" below; we could require students to be on that page for a minute or two before they were allowed to move on.

Figure 1. The Florida Virtual Schools' curriculum in Brainhoney

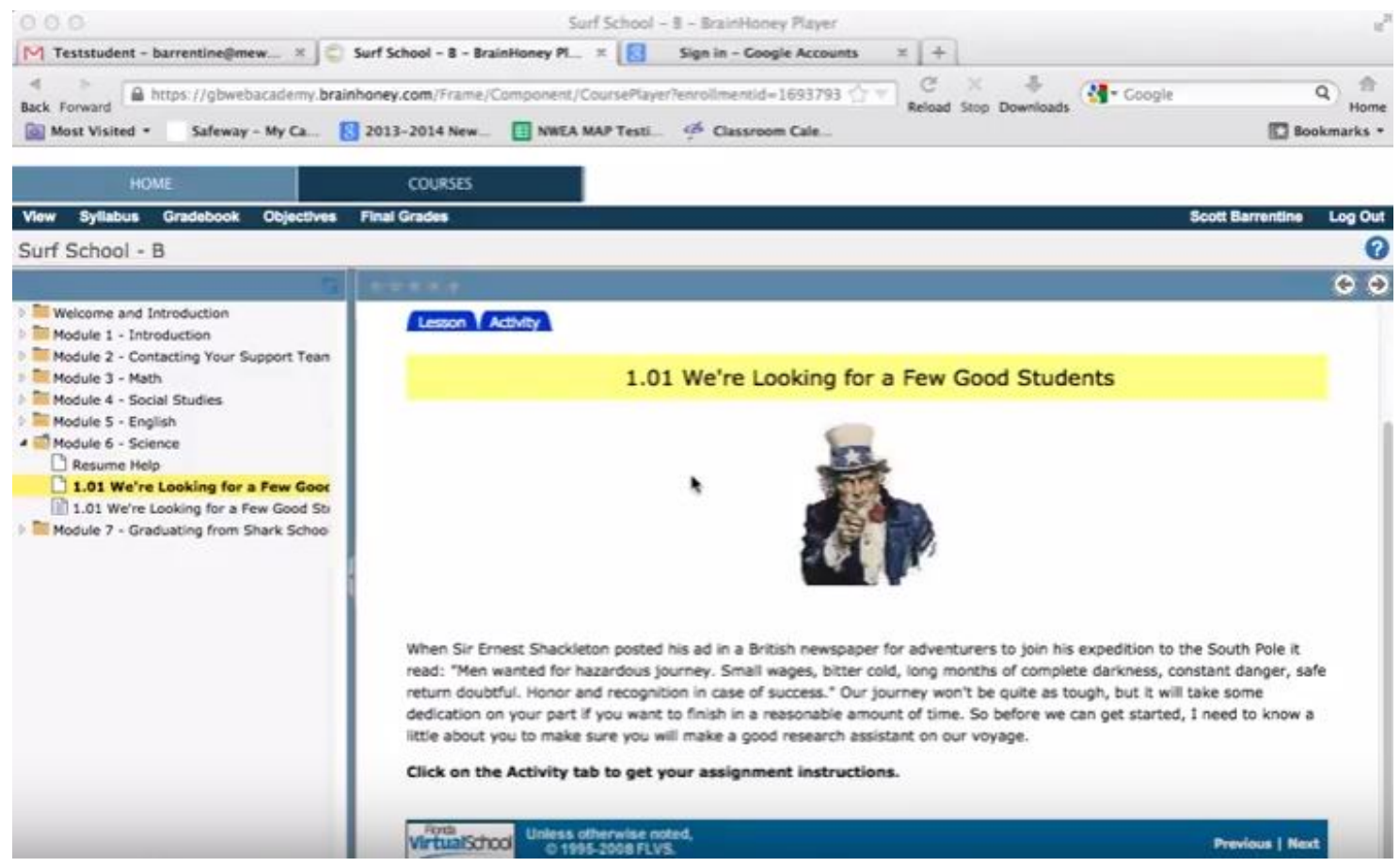


The FLVS curriculum required linear completion of assignments without student choice or ability to prove proficiency and skip ahead. Students were expected to move through the curriculum in order via a schedule that the Brainhoney software filled in for them based on their start and end dates (usually the beginning and end of the semester, but we appreciated the flexibility for transferring students). Students were not penalized for late assignments, but their queue of 'assignments to do' would turn red as they passed those due dates; in my experience, this queue was a major source of anxiety for students, especially if it filled with too much red. The number of assignments past due (“assignments behind," this study's dependent variable) was a crucial number used every day at WES to discuss student progress, as students who were too far behind wouldn't be able to finish by the end of the semester.

WES used a hybrid model for online school, meaning we had a physical building but students were not required to come in (usually). There were open lab times available every day, staffed by regularly-scheduled teachers so students would know when they could come in for specific help. Teachers often had other regularly-scheduled availability as well; for example, I ran science labs every Tuesday and Thursday mornings - students were welcome to come in and work on science work with me during that time, and I had many of the materials necessary for labs available there as well.

The principal of WES expected quick grading turn-around of completed student assignments, preferably less than 24 hours, and the same timeline for responding to communications from students. Grading in particular was seen as a high priority, and the principal would regularly check on teachers' grading queues. Otherwise, teachers had a 
lot of freedom with how they defined and implemented "teacher presence" in their classes. Some (particularly English teachers) had gone so far as to write a whole curriculum from scratch, based on state standards, while others changed almost nothing about the Florida Virtual curriculum, instead concentrating on virtual lectures and consistent contact with students who weren't participating. The motivational effects of these varied strategies were the point of this study, to find which treatment returned the best results in terms of motivating students to complete their coursework on time.

\section{Teacher Practices}

My primary independent variables were the practices of the teachers, analyzed in the Teacher Practices survey (Appendix A), where I asked teachers how often they performed a variety of activities with these options: weekly, 2-3 times a month, once a month, once every couple of months, and "that's not my style." The frequency reflected the priority and time dedicated to those practices. I also asked a few qualitative questions, including if there were any practices not listed here that they did semi-regularly and what they believed were the top three most motivational practices. During data analysis, I grouped these actions into categories, as presented below. Each paragraph represents a practice (or a few similar practices) by describing it factually, reflecting on how I, the researcher, used that practice, and anecdotal evidence of how I observed other teachers using that practice.

The literature (and my experience at conferences about online learning) indicated that teacher presence is often cited as a crucial element to a motivating online environment (Azaiza 2011, Dennis et al. 2007, de la Varre et al. 2014)); how "teacher 
presence" can be expressed, however, is more open to interpretation. The teachers at WES had little guidance beyond the emphasized elements discussed in the treatment section, so their practices varied based on personal preference.

Individual Contact: Students and Parents. Teachers often sent out large group emails to both students and parents using the flexible "Genius" student management system. Teachers could select specific classes and filter who was emailed based on a number of different variables. I often used the filters to send warning emails specifically to parents of students who were more than 3 assignments behind, or congratulatory emails to all students who were on pace. Students received these emails without knowing that they went to everyone, an illusion made easier by the software's ability to put a placeholder like \$NAME that would be replaced with each student's name. There were similar placeholders for 'assignments behind' and other variables, so emails could be crafted that seemed very specific to that student even though they were being sent to every student who met the chosen conditions. Students could respond directly to the teacher, so these emails were a great way to initiate conversation with a lot of students at once - I often included a question so that the conversation could flow. In addition to progress report-style emails, I periodically used mass emailing to remind students of my available hours and promote any upcoming labs that would be available. Other teachers had similar motives with their emails, like announcing an event or attempting to motivate students.

For calling and texting students and parents, teachers were encouraged to set up Google Voice. Google Voice is a free service that provides a separate phone number, 
allowing for texting and calling using your cellphone or computer but without giving students your personal phone number. I used this very regularly, particularly because it was so easy to text directly from a computer, and calls would come into my phone with the disclaimer that it was a Google Voice call so that I could reject them outside of work hours. I found phone contact to be a much more effective means of communication than email, both for students and parents, and being able to use my computer made it easy, particularly after contact had been established. Unfortunately, there was no mechanism for "mass-texting" groups, like was available for email. Administration expected teachers to call and text both students and parents when children weren't engaging with the curriculum, but the system for logging that contact was largely unused.

I asked teachers how often they "go through classes and contact disengaged students" because I saw that as distinct from the previous instruments; calling, texting, or emailing would be the venue for that contact, but specifically combing through classes and establishing contact based on engagement was still a distinct process. For me, this process was both daunting and rewarding; I would delay scheduling time for it because the process was intimidating, having to call home with little real information about the student or parents, but the parents were generally very appreciative about being informed.

Discussion-based Assessments (DBA's) were included in each unit of the FLVS curriculum and required students to contact the teacher and answer questions about the unit. Besides grading, DBA's felt like the closest practice to traditional teaching for me; I used DBA's to both test true student knowledge and lead them to further conclusions. After some experience, I had a general outline for each unit's discussion that involved 
quizzing the key concepts and leading students to the most "take it with you" information that I felt was relevant to their future lives. Getting students to participate in DBA's took some work, because they usually had to schedule a time (or join virtual/physical office hours at set times) and then follow through - I emphasized their responsibility to call in because I felt like that was a good life skill to teach. Other teachers used the DBA as an oral unit test, giving an actual grade based on how well the student answered the questions, but I almost always gave full credit if students conversed with me because I wanted to encourage that contact. Some teachers offered alternatives to these, such as participation in labs or completion of written assignments, but unfortunately I didn't ask any more specific questions about how teachers handled DBA's.

Another frequent point of contact was with teachers' mentees, but expectations for mentor responsibilities were fluid throughout my time at WES, so I will not be studying the effects of that relationship. Each teacher had a 20-30 person mentee group that stayed consistent as students changed grades, although general student turnover was common so teachers frequently gained or lost mentees. I tried to talk to my mentees about once a month, although I adjusted that for students who were doing well but didn't seem to appreciate the contact. Mentor groups were not grouped by age (I repeatedly fought for this in meetings but nothing changed while I was there), so organizing group activities didn't seem effective for 6th-12th graders; some teachers had regular mentor meetings, but participation was minimal for most. There was also a mentor seminar class with one assignment per week, which asked students to reflect on different aspects such as plagiarism or cyber bullying. The "assignments behind" data did not work for this class, 
so I didn't include it. Studying the effects of mentorship, particularly breaking down the practices like I did for this survey, would be a great topic for further study.

I asked teachers how often they engage with students about non-school topics because establishing a relationship with students was tricky in the online environment, but teachers can improve those relationships by not always keeping the focus on school topics (DiPietro et al. 2008). I had trouble initiating these more casual conversations, even though I knew they were important, because it felt forced sometimes, particularly over phone, text, or email. In person meetings made casual contact more natural, which is part of why some of the teachers pushed students to come into the building more often for specific work, clubs, or mentor meetings. I also ran a weekly gaming club for board games and video games, which drew 5-10 kids per week; a few of these students weren't engaged with the curriculum at first but they managed to earn some credits. Other teachers ran clubs as well, including book club, Young Christians, and technology club. We had one very disengaged student who was actually hired by the school to work on student laptops; he never earned credit while I was there, but he did find something to engage in.

Teacher Presence. WES had a regular schedule of "Open Lab" time for students to come in and work, with time available every school day. Teachers were scheduled to supervise these labs, and many teachers shared their schedule with students so they knew when to come in for extra help - like office hours in a college setting. Because all teachers had this time, I didn't ask about it on the survey. I was only on half-time salary, so I didn't have a required time, but teachers knew they could ask me to cover for them. 
The survey asked if teachers ran "Virtual office hours," which were simply an online adaptation; some teachers had a consistent chatroom link that students could follow during those times, while others just advertised that time so that students knew the teacher would be available for contact via Google Hangouts, call/text, or email. Almost every teacher had these available, but in my experience, few students came to my chatroom, so I frequently used it as a time for individual DBA's for the student or two who arrived.

Some teachers made videos of themselves, either teaching a specific topic or using it as a way to connect with students. I made an introductory video for each of my classes so that students could see my face and hear some encouraging words - we had transfer students often enough that frequently somebody was just starting one of my classes. Self-videos were filmed almost exclusively with a Macbook webcam, except for Howell's weekly Tech video, which was not specifically part of any class and used a friend's camera. Some teachers used videos to introduce themselves to their classes at the beginning of the class, which students would access whenever they began, while the teachers who did it more commonly used it to make encouraging videos.

"Posting announcements in Brainhoney" was a similar practice to mass emailing, but without the filters. The announcement would appear to students when they logged into the course. Since one of our biggest problems was students who weren't even logging in regularly enough, Brainhoney announcements had limited value as an initial motivational tool. I used these occasionally to inform students about lab opportunities, link to my blog, and promote gaming club, but this practice was not common. 
Only two teachers updated a blog regularly, and they had different goals in doing so. I wrote a topical science blog updated on Tuesdays and Thursdays. My goal was to show that science was still happening in the present and sneak some knowledge in around engaging topics. I started the blog partially because I didn't feel like I was doing enough work to justify my salary, even though it was half-time (I had half the traditional number of classes and students as well). I'm not sure how many students I was actually reaching, but sometimes I embedded blog posts into the middle school curriculum when they expanded on topics, so blogging occasionally doubled as curriculum creation. Students were frequently off the scheduled pace, so a class-based blog would have been tricky to implement and would only benefit the on-pace students, who were already succeeding. Howell's blog was more about tech issues and motivation; he would often film himself giving a motivational message and explaining interesting technology news.

Improving Class Experience. Some teachers ran labs with a specific plan (not Open Lab or office hours). These labs were occasionally a chance to fulfill a specific assignment, like when I scheduled lab times where I provided materials for a required science experiment that asked students to gather materials at home. I would post announcements in Brainhoney and send out mass emails alerting students that I would be available from 9am-noon on Tuesday and Thursday if they wanted to complete one of three possible labs. English teachers sometimes invited specific students to participate in a seminar on a certain skill, like using proper citations or writing a persuasive essay. These labs could closely approximate more traditional teaching, but getting students to come in on a schedule was always tricky, particularly the less-engaged ones. 
Teachers could also conduct virtual organized lectures or classes. Generally, these started at a specific time, occasionally offering one alternate time as well, and participation could give credit for a DBA or replace another assignment. I tried these a few times, but only a few students would show up and they were almost always already on pace and passing, so I moved away from them. Virtual classes were a frequent source of discussion; teachers debated whether these should (or even could) be required, how they could count towards credit, and the eternal question: how to motivate disengaged students to participate in them.

"Writing new curriculum" involved changing what students worked on to earn credit. The school paid for the Florida Virtual School (FLVS) curriculum, which had been developed for a long time and provided mostly great interactive lessons and application of knowledge assignments, but the curriculum was ubiquitous enough that many of the assessment questions were answered on Yahoo Answers and other sites. I sometimes changed test questions that were commonly plagiarized, but replacing the curriculum seemed like more work than it would be worth, particularly since my new curriculum wouldn't have the games and graphically-designed interface of the FLVS stuff. The English teachers had replaced some entire courses with their own curriculum, but for most teachers, writing new curriculum meant replacing an assignment in the FLVS curriculum - and that integration would be very noticeable to the students because the new lesson looked so different. Plans were often floated to re-work whole courses over the summer, particularly for middle school, but they did not come to fruition in my 
time there; administration would have even paid extra to teachers for writing new courses since it would mean they didn't have to pay FLVS.

"Making videos of the class" involved using screen-capture technology to record what was on the teacher's computer screen while narrating over it. I made videos for some of the trickier assignments in my classes, and I used this method a lot in "Surf School," the course I wrote for new students. Other teachers used this strategy to walk students through how to turn in an assignment, or they recorded a specific section of the curriculum to help students understand what to do, directly teaching concepts like research or essay writing. I pushed for the purchase of a quality streaming camera that could be used to film a physical class while students participated both online and in the school building, but that was never acquired, so this question did not refer to a video of a classroom of participating students - the technology wasn't available.

Meetings/Preparation. Meetings were a regular part of teacher life at WES, including a long weekly staff meeting every Monday. I asked teachers how frequently they attended meetings with other teachers because of a committee and how often they met with teachers for collaboration on practices, strategies, and curriculum. The committees included OAKS testing, summer preparation, next year's scheduling concerns, and work on the Mentor Seminar class.

The last practice that I asked about doesn't seem to fit into any of the previous categories: "How often do you automatically allow retrys on assignments?" When students turned in an insufficient assignment, teachers had the option of allowing a retry on that assignment. Some teachers automatically clicked "Allow Retry" on any 
assignment that wasn't good enough, but others required contact with the teacher or proof of further work before they would allow a retry. I believed students should continue work until they got it right (more of a proficiency model), so I wanted to see the effect that automatically allowing these retries had on student motivation. Allowing retries could have been frustrating for students though, because it reversed the sense of accomplishment they got from completing an assignment - although frequently if a retry was allowed, that sense of accomplishment was invalid anyway. There's also a distinct difference between assignments that earned some credit but didn't score very well and assignments that students barely worked on and just turned in to get them out of their 'due soon' queue; I would allow retries on both types, but perhaps I shouldn't have allowed a retry when sufficient work was done but I thought that student could have done better.

Teacher Availability. This category only includes the two questions that I didn't ask for a 1-5 scale ranking on: "How fast is your grading turnaround?" And "How quickly do you respond to student emails?" The possible answers are displayed in Table 1, with the 1-5 scale that I gave them in data analysis.

Table 1. Scoring Grading and Response Time Answers in Teacher Survey

\begin{tabular}{|l|c|}
\hline Grading Time: & Score: \\
\hline Same Day & 5 \\
\hline Within 24 hours & 5 \\
\hline Within 36 hours & 3 \\
\hline Within 48 hours & 2 \\
\hline 2-4 days & 1 \\
\hline
\end{tabular}

\begin{tabular}{|l|c|}
\hline Response time: & Score: \\
\hline Within a couple of hours & 5 \\
\hline Same Day & 4 \\
\hline Within 24 hours & 3 \\
\hline Within 36 hours & 2 \\
\hline Within 48 hours & 2 \\
\hline 2-4 days & 1 \\
\hline
\end{tabular}


I measured the effectiveness of these various teaching strategies by ranking the teachers using assignments-behind-pace data (see the Data Analysis: The Dependent Variable section for more on that) and finding the practices that were more frequently used by the more effective teachers.

\section{Instruments}

Teacher Survey of Practices (Appendix A-1): I wrote this survey listing the practices I described in the treatment section. I asked teachers how often they performed each practice with these options: weekly, 2-3 times a month, once a month, once every couple of months, and "that's not my style." The frequency reflected the priority and time dedicated to those practices. I also asked a few qualitative questions, including if there were any practices not listed here that they did semi-regularly and what they believed were the top three most motivational practices.

Student Affective Survey (Appendix A-2): The Affective Variable Survey for students is a Common Measures survey (Saxton et al. 2014) that analyzes student academic identity and motivational resilience, which I modified for the online environment. The statements in the survey are subject-specific (I asked about Math, Science, and Technology) and they ask students to agree or disagree based on the following scale:

\begin{tabular}{|c|c|c|c|c|}
\hline $\begin{array}{c}\text { Not at all true } \\
1\end{array}$ & $\begin{array}{c}\text { A little bit } \\
\text { true } \\
2\end{array}$ & $\begin{array}{c}\text { Somewhat } \\
\text { true } \\
3\end{array}$ & $\underset{4}{\text { Fairly true }}$ & $\underset{5}{\text { Totally true }}$ \\
\hline
\end{tabular}

There are categories within each subject that use student language to ascertain the student's opinion of his or her own academic identity, relatedness, competence, 
autonomy, purpose, engagement, and resilience. I changed some of the questions that seemed to apply to the classroom environment and eliminated some of the 'drill' questions (which are considered optional) to keep it brief.

This survey's validity comes from its source: the common measures proposed by Emily Saxton et al (2014). Also benefitting both reliability and validity are the 'negative' statements present in this survey; for example, the survey asks students the level to which they agree with both "I am the kind of person who can succeed in Math" and "People like me do not get jobs in Math." If these answers contradicted each other in data analysis, the student likely did not think heavily on his or her responses.

\section{Student Survey of Teacher Practices and Student-Teacher Relationships}

(Appendix A-3): This survey was divided into two parts: asking students to rate each teacher action based on how motivational it was, and the modified Common Measures Student-Teacher Relationship survey. The survey involved the same set of questions twice: once for the student's math teacher and the other about his or her science teacher. Students rated teacher actions on the following scale: "My teacher doesn't do this," "This discourages me," "This is not motivational," "I'm motivated by this," and "This really motivates me." "My teacher doesn't do this" is a particularly interesting designation, indicating a lack of teacher presence in that area.

I added a few elements to the student version of the teacher practices survey: "Schedules a meeting with you in person" and "Uses encouraging language when grading assignments" are both in the "Other" category with asking about your personal life, and "Makes a template of an assignment" joined the "Improving Class Experience" category. 
Otherwise, these practices match what I asked teachers and can be divided into the same categories.

The PSMP Common Measures Student-Teacher Relationship section of the survey asked students to rate statements about "My [Science/Math] Teacher..." on a scale from 1-5 with the following statements: “(1) I don’t know/can’t tell," “(2) Not at all true,” “(3) A little bit true,” “(4) Fairly True,” and “(5) Totally True.” The “(1) I don’t know/can't tell" rating is especially interesting here because it indicates a lack of teacher presence during the course. This survey is split into categories, most of which involve the teacher: Involvement, Structure (weird category title), Autonomy Support, Teacher Engagement, and Communications. The "Authentic Academic Work" category almost exclusively asks about the curriculum, rather than the teacher, which made it a good comparison point during data analysis. I also invented the first of this survey, so it lacks external validity, but the second half comes from Emily Saxton et al.'s Common Measures paper (2014).

\section{Procedure}

All surveys were sent out using the standard WES communications for new items: a mass email, an announcement in the Learning Management System, and a blurb in the weekly Principal's Message. Students (and their parents) were asked to participate in the surveys and promised entry into a drawing for a gift card, even if they don't wish to have their data used, as long as they answered the two surveys. The survey link was provided by PSU faculty advisor Melissa Potter, who coded the results so I could analyze them anonymously. 
The Teacher Practices survey was sent out first, in April, requiring only consent from the teachers to have their data used. The data was not anonymized for the researchers, for practical purposes, but the names have been changed in this thesis. The Student Affective Survey went out soon after, measuring the academic identity and motivational resilience of students and asking them for their assent to have their data used for the research study. Parental Consent surveys were sent out at the same time, and both initial surveys provided a link to the other in the hopes that more students would participate. Then the student survey on teacher practices was sent out to everyone who participated in the first survey, along with a fresh announcement from the school asking for participation in both surveys.

Melissa Potter used the information from the Student Affective Variable Survey to code the 23 students who participated out of the massive spreadsheet by finding and replacing each name with a ZzXX designation, where the X's were distinguishing numbers. She then deleted the rest of the students, leaving the data from two different points in each semester (four total) for students Zz01 through Zz23. That data was used in conjunction with the affective variable survey (coded with the same ZzXX names) to draw conclusions about how the students' affective variables in Math, Science, and Technology correlated with how many assignments behind students were. Three students answered the second survey as well, Zz08, Zz18, and Zz23, and I studied them more in depth based on their answers to both surveys and their assignments behind data. 


\section{The Dependent Variable: Metric for Success}

My method for measuring engagement involved the number of "assignments behind" each student was in each class. When a student was enrolled in a class, the Brainhoney software would automatically populate a calendar, spreading the due dates of all the assignments in the class across the semester. If students let those due dates pass, there was no penalty to their grade, but the system would track how many assignments were "past due." Joshua Sanstrum, a non-teacher faculty member at WES, pulled the "assignment behind" data for every student in the school four times over the year, with about four weeks and one week left in each semester for the purposes of tracking and data analysis. Because this data was already being collected and used by the school, I did not need assent when I used it to measure the effectiveness of teachers based on how many of their students were too far behind pace. I also had that data coded for the 23 students who participated in the surveys so that I could analyze them, but for the purposes of ranking the teachers, the entire school's data made for a much better argument. Once I had a ranked list of teachers, I averaged the practice frequency of the top four teachers and bottom four teachers and found the difference so I could draw conclusions about which practices are most effective.

I initially thought I would simply average the "assignments behind" for each teacher, so teachers with a lower average "assignments behind" number would be measurably more effective at engaging their students. All assignments were not created equal, however, because classes had different number of assignments, so for each class I divided each student's assignments behind by the total assignments in that class and 
averaged the result, giving an average percent behind. Averaging those percentages for all of a teacher's classes gives the average percent-behind-pace for the students of that teacher. I also calculated the percentage of each teacher's students that were more than $20 \%$ behind pace, because generally students did not finish classes that were that far behind, particularly with one week left in the semester which is when half this data was gathered. Ultimately, I decided that this second number that approximates what percentage of students will fail to finish the course was the more important number for ranking the teachers, because average-percent-behind was skewed by students who had totally given up. I believe the percentage of students more than $20 \%$ behind pace accurately measured the portion of students who were failing for that teacher because they weren't engaging in the course, which seems more important than the average assignments-behind-pace that students were.

I chose to leave some data out of the final teacher averages, like Martin's art classes (which ended up improving her numbers but did not affect her top-ranking) and Goudy's Keyboarding classes because that class involved very little teacher interaction. I also ignored Cook's Writing 121/122 classes because they were dual-classes with college credit and the population of students was not representative of the overall school. If I had not made these changes, the rankings would not have been different (the top four and bottom four teachers remained the same), but I still felt I needed to adjust these for the sake of accuracy. I also used weighted averages for the three teachers, (Corona, Everett, and Goudy) who taught different high school subjects, so to get the final, averaged percent of students who were more than $20 \%$ behind I weighted the averages by the 
number of students in those different subjects; for example, Everett only had 25 math data points and 486 from science, so I used a simple proportionally-weighted average to calculate her overall percentage. I did the same thing for Martin, Goudy, and Reed to reach my middle school rankings, but this time I included keyboarding because the middle school population was so uniform. 


\section{Results}

\section{Analysis of Teacher Survey of Practices}

The survey I sent to teachers can be found in Appendix A-1 and the resulting data is in Appendix B-1. I'll start this section with a general summary of how teachers are spending their time, then present each teacher's practice frequencies and effectiveness

data in ranked order, starting with the teacher who has the fewest students more than $20 \%$ behind pace in the course.

In general, teachers at WES spent about half their time grading student work. In my experience, the grading queue represented the most immediate and measurable metric for how "on top of things" a teacher felt on a given day. Administration also emphasized that all work should be graded within 2 school days after submission, so this priority made sense; grading was also the primary contact between teachers and students, since the course information and assignments were provided by the Florida Virtual School (FLVS) for almost all classes.

The most common teacher actions after grading all involved contacting students in a variety of ways; mass emails to students were most frequent, followed by emailing parents, texting and calling students, engaging with students in "Discussion-based Assessments (DBA's)," then calling and texting parents or guardians. Teachers had varied methods for contact: most held "virtual office hours" at set times each week so students would feel comfortable contacting them, and all teachers had shifts in the "open lab" that was available each day for students to come in and work. Some teachers ran 
physical or virtual labs that were more organized and allowed students to fulfill their DBA obligations.

Almost every teacher, with the exception of myself, reported frequent (at least 2-3 times per month) meetings with other teachers, both to serve on a committee and to collaborate with other teachers on practices, strategies, and curriculum. This is the most surprising data for me. I studied 9 of the 12 total teachers at the school and they averaged 11 "preps" (individual, distinct classes) per semester with little overlap and tiny departments, so I'm not sure of the nature of these meetings. The phrasing of these 2 questions indicated that the weekly staff meeting did not count towards the frequency of meeting with other teachers. I am skeptical of how much relevant collaboration occurred, as no two teachers taught the same class, so writing curriculum together seems improbable. We did have an informal meeting once where a few teachers shared some tricks and the processes they were using; it was the most productive meeting of my time at WES, but we never did it again. My experience with meetings at WES (and other educational environments) involved a lot more identifying the problem than working on solutions. Because almost every teacher chose "Weekly" for this question and the practice of attending meetings doesn't directly affect student success, I will not be drawing conclusions for this category.

As I analyzed the data, I realized that the differences between teachers relied on the variance of the data; for example, if almost every teacher texted students regularly (which they did), then we can't really analyze that practice because there will not be sufficient variation to distinguish between teachers. Here are the standard deviations for 
each practice, split into two columns for improved readability: the top half standard deviations and the bottom half. "Conduct virtual office hours" is crossed off here because it showed a high standard deviation number, but every teacher reported doing it weekly as required by administration except for Cook who chose "that's not my style."

Table 2. Standard Deviations of each Teacher Practice

\begin{tabular}{|l|c|}
\hline High Standard Deviations: & STDEV: \\
\hline $\begin{array}{l}\text { Grade work soon after its } \\
\text { turned in }\end{array}$ & 1.79 \\
\hline $\begin{array}{l}\text { Conduct virtual organized } \\
\text { lectures or classes }\end{array}$ & 1.69 \\
\hline Update a blog for students & 1.66 \\
\hline Write new curriculum & 1.36 \\
\hline $\begin{array}{l}\text { Post announcements in } \\
\text { Brainhoney }\end{array}$ & 1.36 \\
\hline $\begin{array}{l}\text { Conduct virtual office hours } \\
\text { Make videos of yourself }\end{array}$ & 1.33 \\
\hline $\begin{array}{l}\text { Run a lab with a specific } \\
\text { plan, rather than open lab or } \\
\text { office hours }\end{array}$ & 1.32 \\
\hline $\begin{array}{l}\text { Talk with students } \\
\text { individually for Discussion- } \\
\text { based Assessments }\end{array}$ & 1.20 \\
\hline
\end{tabular}

\begin{tabular}{|l|c|}
\hline Low Standard Deviation: & STDEV: \\
\hline Call Parents & 1.13 \\
\hline Email Parents & 1.13 \\
\hline Make videos of your class & 1.12 \\
\hline Call students & 1.00 \\
\hline Text Parents & 1.00 \\
\hline $\begin{array}{l}\text { Respond quickly to student } \\
\text { emails }\end{array}$ & 0.87 \\
\hline Check in with mentees & 0.83 \\
\hline $\begin{array}{l}\text { Text with students } \\
\text { contact disengaged students }\end{array}$ & 0.71 \\
\hline
\end{tabular}

Table 2 Color Key:

Teacher Presence

\begin{tabular}{|l}
\hline Individual Contact with \\
Students \\
\hline Improving Class \\
Experience
\end{tabular}

Parent Contact Teacher Availability 
We can see here that almost all of the individual contact practices have very little variance between teachers, which makes sense: they were the most clearly expected practices by administration, along with responding quickly to emails and grading time although grading time anomalously showed the most variation. The Teacher Presence and Improving Class Experience categories represent the most flexibility in terms of teacher choice, and the data agrees with that conclusion.

Every teacher reported regularly engaging with students about non-school topics, conducting virtual office hours (expected by administration, only one teacher, Cook, didn't do this), sending out large group emails, and emailing parents (with two exceptions). In the interest of reducing repetition, I won't mention these in the following teacher profiles unless the teacher is an exception.

\section{Teacher Data Analysis}

In order to rank teacher effectiveness, in each class I counted the number of students who were more than $20 \%$ behind pace and divided that by the total students in the class. Averaging those numbers gives each teacher's percentage of students who were more than $20 \%$ behind pace, which is the number I used for the ultimate ranking and the order the teachers are presented in. Table 3 and the following teacher profiles are presented in ranked order using the high school data, from the teacher with the best (lowest) percent of their students more than $20 \%$ of the assignments in the class behind pace to the teacher with the worst (highest) number.

In Table 3, "Number of Student data points (total)" is phrased that way because this data was parsed from one combined spreadsheet with four different measurement 
times (two per semester). Almost every student is counted twice because of the two measurement times in a semester, and because the data is taken from two semesters, teachers did not have all their students at once; the true number of students a teacher had at any given time is about one-fourth of the number represented here. The Average percent of students $>20 \%$ A.B. is the ultimate number that was calculated as described in the previous paragraph, divided for each subject area that a teacher teaches, then I averaged those using a weighted average (by number of students per subject).

Table 3. High School Teacher Rankings

\begin{tabular}{|l|l|c|c|}
\hline Teacher & \multicolumn{1}{|c|}{ Subject(s) } & $\begin{array}{l}\text { Number of } \\
\text { Student data } \\
\text { points (total) }\end{array}$ & $\begin{array}{l}\text { Percent of High } \\
\text { School students more } \\
\text { than 20\% behind }\end{array}$ \\
\hline Martin & $\begin{array}{l}\text { H.S. art, M.S. art, math, and social } \\
\text { studies }\end{array}$ & 410 & $38.13 \%$ \\
\hline Howell & $\begin{array}{l}\text { H.S. Social Studies and } \\
\text { Psychology }\end{array}$ & 619 & $39.72 \%$ \\
\hline Reed & $\begin{array}{l}\text { H.S. Health, Food Safety, and } \\
\text { Healthy Cooking; M.S. Health } \\
\text { and Language Arts }\end{array}$ & 746 & $42.14 \%$ \\
\hline Cook & H.S. English & 412 & $45.39 \%$ \\
\hline Everett & H.S. Science and a little Math & 511 & $52.10 \%$ \\
\hline Corona & H.S. English and Economics & 488 & $60.26 \%$ \\
\hline Diphily & H.S. Math and a few M.S. Math & 467 & $61.50 \%$ \\
\hline & $\begin{array}{l}\text { H.S. Math and Physical } \\
\text { Education; M.S. Math and } \\
\text { Keyboarding }\end{array}$ & 382 & $62.65 \%$ \\
\hline Goudy & H.S. Science and M.S. Science & 420 & $64.76 \%$ \\
\hline Barrentine & & & \\
\hline
\end{tabular}

Table 3 shows our top high school teacher was Martin, who taught only art at the high school level; because art was one of our only electives, it feels unfair to say that her 
practices were the reason for this top ranking, so I don't want to compare her practices to other teachers'. Howell, Reed, and Cook were next, all with less than $46 \%$ of their students more than $20 \%$ behind pace. Every subject except science was represented in this top tier. Everett, who taught almost all science, sat in the middle with $52.1 \%$. Then the remaining four teachers were all over 60\%: Corona, Diphily, Goudy, and Barrentine, who taught all the core subject areas between them.

In the 'number of student data points' column, we see that Howell and Reed had the most students. Some classes for Cook and Goudy were not included here (as discussed in the Procedure section), so their numbers don't accurately reflect their workload, but everyone else had all their classes included in this listings. I (Barrentine) was the only half-time teacher, but that is not reflected in these student numbers - I had six preps compared to most teachers' $10-12$, but about the same total-student responsibilities.

The middle school rankings were very different, however, as the bottom three high school teachers were the top three middle school teachers, with top-ranked high school teacher Martin essentially tied with Reed with the worst middle school score, around $36 \%$ behind pace. 
Table 4. Middle School Teacher Rankings

\begin{tabular}{|l|l|c|c|}
\hline \multicolumn{1}{|c|}{ Teacher } & \multicolumn{1}{|c|}{ Subject(s) } & $\begin{array}{l}\text { Total Middle } \\
\text { School data } \\
\text { points }\end{array}$ & $\begin{array}{l}\text { Middle School } \\
\text { more than 20\% } \\
\text { behind }\end{array}$ \\
\hline Diphily & H.S. Math and a few M.S. Math & 43 & $30.13 \%$ \\
\hline Barrentine & H.S. Science and M.S. Science & 206 & $32.21 \%$ \\
\hline Goudy & $\begin{array}{l}\text { H.S. Math and Physical Education; } \\
\text { M.S. Math and Keyboarding }\end{array}$ & 184 & $34.70 \%$ \\
\hline Martin & $\begin{array}{l}\text { H.S. art, M.S. art, math, and social } \\
\text { studies }\end{array}$ & 272 & $36.34 \%$ \\
\hline Reed & $\begin{array}{l}\text { H.S. Health, Food Safety, and Healthy } \\
\text { Cooking; M.S. Health and Language } \\
\text { Arts }\end{array}$ & 296 & $36.78 \%$ \\
\hline
\end{tabular}

Apparently middle school students were encouraged by very different approaches! This data also shows how much more on pace our middle school students were, as even the worst number is lower than the best high school number. Reed had the most data points because she had multiple required middle school courses, while Diphily only dabbled in middle school math.

\section{Teacher Profiles:}

I analyzed the data from the teachers' responses to the "Teacher Survey of Practices" by changing the named frequencies (Weekly, 2-3 times per month, etc.) into simple 1-5 numbers, where one indicates something the teacher didn't do and five represents practices that were done weekly. After dividing the practices into groups (student contact, parent contact, teacher presence, improving class experience, and meetings), I averaged the numbers for each teacher from each group to give a quick picture of what that teacher seems to be spending the most time doing (Figures 1-9). Then 
I wrote a general profile for each teacher based on their answers to the surveys and their numbers from the assignments-behind data analysis.

The average Assignments Behind (A.B. \%) comes from looking at each class as a group (including usually two data points for each student from each semester) and dividing the number of assignments behind by the overall assignments for each class, then averaging all the classes that a teacher has in that category. Average students per class is once again double-counting a lot of students, so that number is only useful for comparing to other teachers - bigger numbers mean the teacher has less individual classes, or 'preps.'

Figure 2 - Martin's Teacher-action Distribution

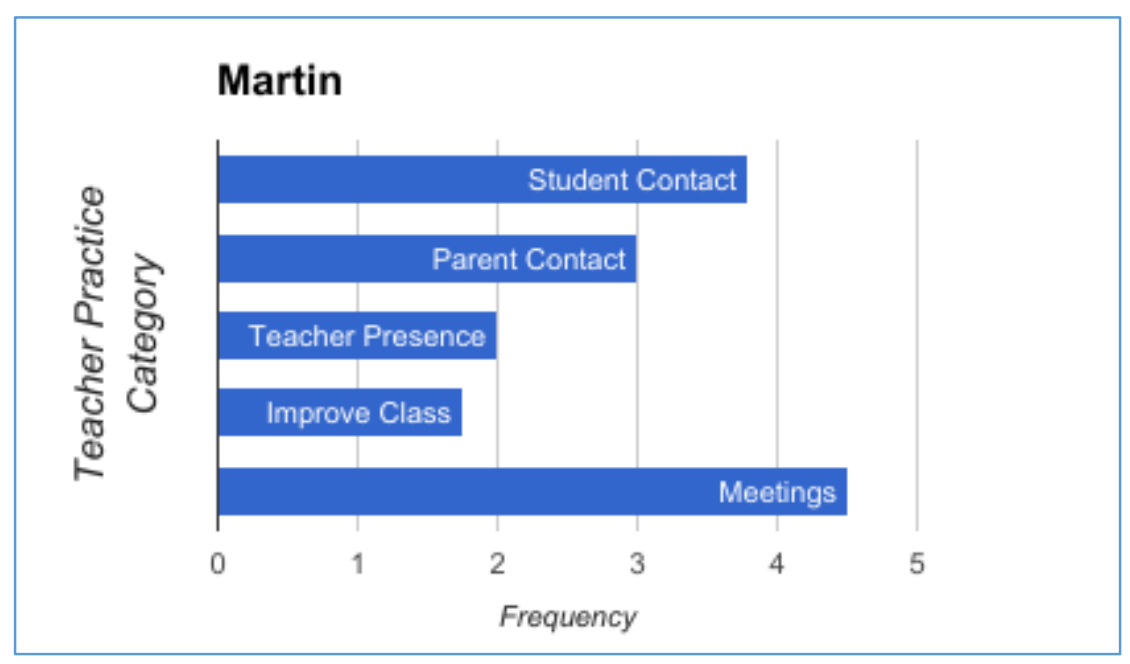

Martin had a few unique features as a teacher. She began the year as a half-time art teacher and was moved to full-time for the 2 nd semester, giving her 6 th and 7 th grade math and social studies classes. She reported a slow grading time of 2-4 days, but responded to student emails within 24 hours. She texted and called less than other teachers, only contacting parents in those ways once every couple of months, but she did 
email parents every week, along with sending out weekly large group emails like most teachers. She did not make videos or a blog, and she reported rarely writing new curriculum and running specific labs, virtual or physical. Martin also met weekly with teachers for committee purposes, but less often (2-3 times per month) collaborated on practices, strategies, or curriculum. She also conducted weekly virtual office hours and talked individually with students for DBA's every week.

Martin's mindset and priorities were more clear in her answers to the freeresponse section of the survey. Martin used true hybridized classes for art, with weekly physical meetings, and she reported spending about $50 \%$ of her time working directly with students, either in person or online. She also took her art classes on a field trip at least once per semester, and she wished she had more time to "be creative with building more ways to interact with students." Her top three things teachers can do to motivate students were: "Make work relevant, make personal connections, and expect the best from every student."

Table 5. Martin's Subject breakdown

\begin{tabular}{|ll|c|c|c|}
\hline & Martin & $\begin{array}{c}\text { Number of } \\
\text { Student data } \\
\text { points }\end{array}$ & Average A.B. \% & $\begin{array}{c}\text { Average Percent of } \\
\text { Students >20\% A.B. }\end{array}$ \\
\hline H.S. Art & 138 & $20.69 \%$ & $38.13 \%$ \\
\hline M.S. Math & 41 & $21.78 \%$ & $34.72 \%$ \\
\hline M.S. Social Studies & 198 & $20.69 \%$ & $36.67 \%$ \\
\hline M.S. $\quad$ Art & 33 & $16.50 \%$ & $23.67 \%$ \\
\hline
\end{tabular}


As mentioned before, Martin's math and social studies students were added in the second semester; her primary focus was on art. As one of our only elective options, art's high participation numbers made sense, and because she didn't rank highly with her middle school students' engagement numbers, I didn’t include Martin's practices data in our final conclusions about the most effective practices for high schoolers.

Figure 3 - Howell's Teacher-action Distribution

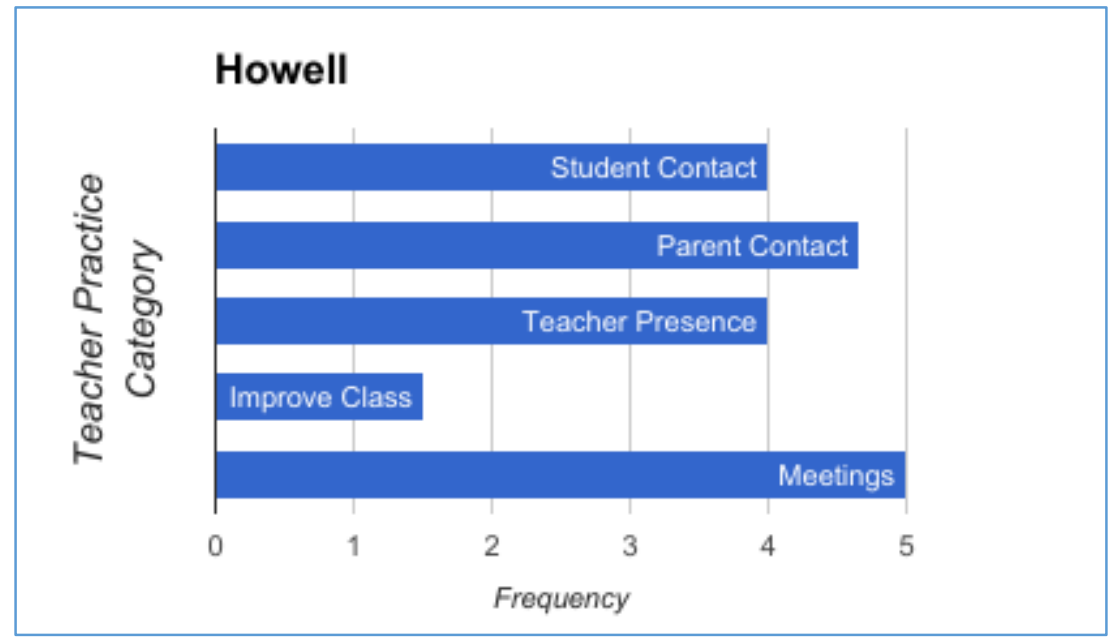

Howell taught almost all of the social studies courses at WES. He reported spending $45 \%$ of this time grading, and got his grading done within 24 hours of the assignment being submitted. He put a lot of emphasis on personal contact with students, answering emails within a couple of hours and using email, texting, calling, and videos of himself to reach out to students and mentees every week. He also blogged and had virtual office hours weekly. He met weekly with teachers and reported contacting staff 6 hours a week; he wished he had more time to help other staff be more efficient. He did not spend time writing new curriculum (but he did add that he modifies coursework regularly) or running labs, either physical or virtual, and he must have designed a work-around for the 
Discussion-Based Assessments because he rarely spoke with students for those. Overall, I would characterize his priorities to lie with ensuring that students were aware of his online presence, which is a key factor in online teaching.

Table 6. Howell's Subject Breakdown

\begin{tabular}{|ll|c|c|c|}
\hline Howell & $\begin{array}{c}\text { Number of } \\
\text { Student data } \\
\text { points }\end{array}$ & Average A.B. \% & $\begin{array}{c}\text { Average Percent of } \\
\text { Students }>\mathbf{2 0 \%} \text { A.B. }\end{array}$ \\
\hline H.S. & Social Studies & 543 & $23.70 \%$ & $41.97 \%$ \\
\hline H.S. & Psychology & 76 & $14.63 \%$ & $23.68 \%$ \\
\hline
\end{tabular}

Howell's assignments-behind numbers are very strong, although I would argue that social studies is one of the easiest subjects to adapt to online school, with its emphasis on raw information, reading, and typed responses. Psychology is another elective with very good marks, which is unsurprising: students had to choose elective classes, indicating interest and giving them buy-in.

Figure 4 - Reed's Teacher-action Distribution

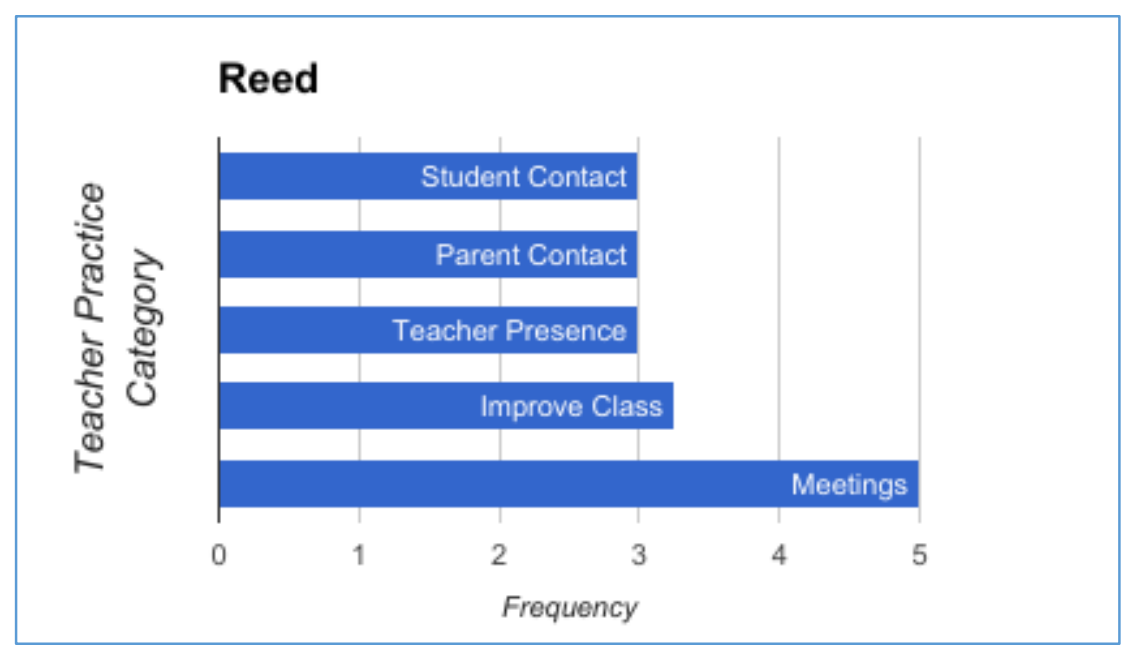

Reed worked $50+$ hours per week and reported spending $40 \%$ of her time on grading, which she completed in 2-4 days. She responded to student emails within 24 
hours, but she was unique amongst teachers by only doing the following actions once per month: call students/parents, text and email parents, and talk individually with students for DBA's. She did text with students 2-3 times per month, along with checking in with her mentees, but her main focus was on weekly virtual meetings - which were required for her classes, which was unique at WES. She only made videos, updated her blog, and went through classes to contact disengaged students once every 2-3 months.

Reed was also slightly distracted from traditional teaching duties by her large testing requirements (reporting spending 30\% of her time doing it), as she was in charge of WES's OAKS testing, which was quite involved. Like most teachers, she spent a lot of time in meetings. Her top three things teachers can do to motivate students were to “develop relationships, inspire intrinsic motivation, and [conduct] interventions." She wished she had more time to seek out struggling students.

Table 7. Reed's Subject breakdown

\begin{tabular}{|l|c|c|c|}
\hline \multicolumn{1}{|c|}{ Reed } & $\begin{array}{c}\text { Number of } \\
\text { Student data } \\
\text { points }\end{array}$ & Average A.B. \% & $\begin{array}{c}\text { Average Percent of } \\
\text { Students }>20 \% \text { A.B. }\end{array}$ \\
\hline $\begin{array}{l}\text { H.S. Health, Food } \\
\text { Safety, and Healthy } \\
\text { Cooking }\end{array}$ & 450 & $24.35 \%$ & $42.14 \%$ \\
\hline M.S. Health & 98 & $19.40 \%$ & $34.12 \%$ \\
\hline M.S. Language arts & 198 & $21.11 \%$ & $38.10 \%$ \\
\hline
\end{tabular}

Reed's data shows our consistent finding that middle schoolers are significantly more engaged than high schoolers, but M.S. Language Arts represents the worstperforming class in all of middle school. Reed's classes aren't core subject areas except 
that Language Arts, so perhaps her classes' content was more the reason she's in the tophalf of teachers, but Health was a required class. She also had more students than any other teacher; her classes were larger though, so she didn't have more preps.

Figure 5 - Cook's Teacher-action Distribution

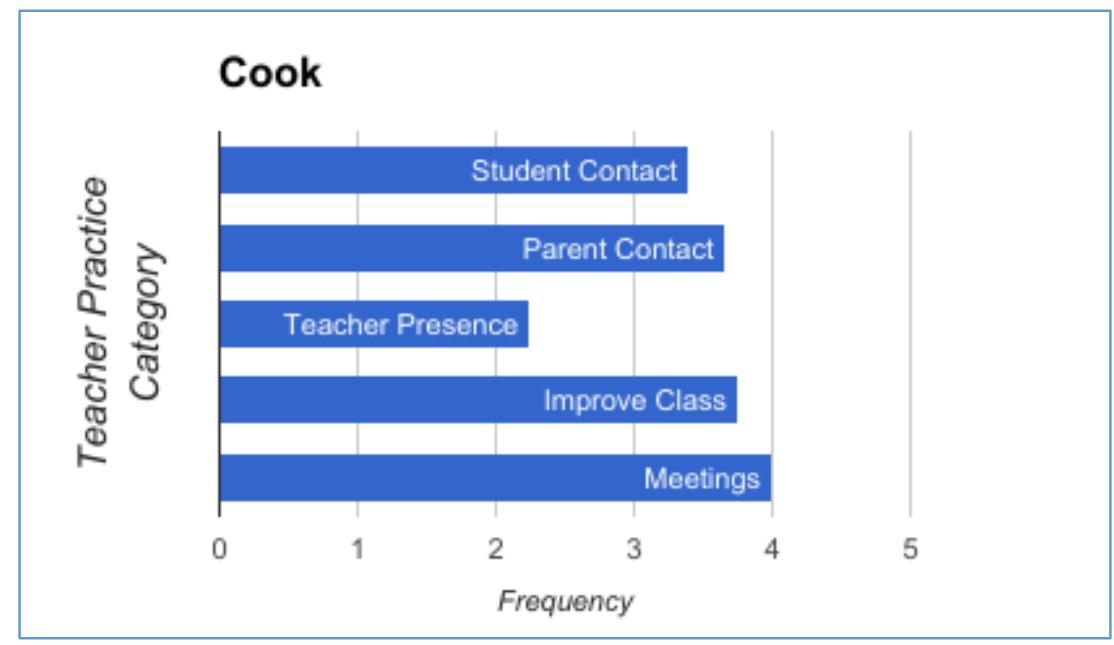

Cook, an English teacher, had some of the most unique features to her teacher practices. She still graded and responded to students within 24 hours, but reported texting and calling students and parents only once per month. She emailed parents and sent out large group emails every week though, and reported answering emails for $25 \%$ of her total work time. Her other main emphasis was writing new curriculum; Cook had created whole classes that were separate from the FLVS curriculum. She met with teachers and ran specific labs in the building 2-3 times per month, but every other practice she reported at once per month or less. She specifically mentioned meeting face-to-face with students very regularly, both academically and for clubs, and her "top 3 things teachers can do to motivate students" reflected her time priorities: 
1. Develop a personal relationship with the students.

2. Use a variety of means to communicate with students and families.

3. Make the information interesting and relevant.

Table 8. Cook's Subject breakdown

\begin{tabular}{|l|c|c|c|}
\hline \multicolumn{1}{|c|}{ Cook } & $\begin{array}{c}\text { Number of } \\
\text { Student data } \\
\text { points }\end{array}$ & Average A.B. \% & $\begin{array}{c}\text { Average Percent of } \\
\text { Students }>\mathbf{2 0 \%} \text { A.B. }\end{array}$ \\
\hline H.S. $\quad$ English & 370 & $24.47 \%$ & $45.39 \%$ \\
\hline H.S. $\quad$ Writing 121/122 & 42 & $3.19 \%$ & $4.67 \%$ \\
\hline
\end{tabular}

Cook was the only teacher with only one subject area; I separated the Writing 121/122 class because the numbers aren't even close to any other class at WES. That class was dual credit, so students could earn college credit for participating, and as you can see students did very well. She also ran a few clubs and assumed a leadership position after I left; Cook's spot as a top-level teacher is unquestionable.

Figure 6 - Everett's Teacher-action Distribution

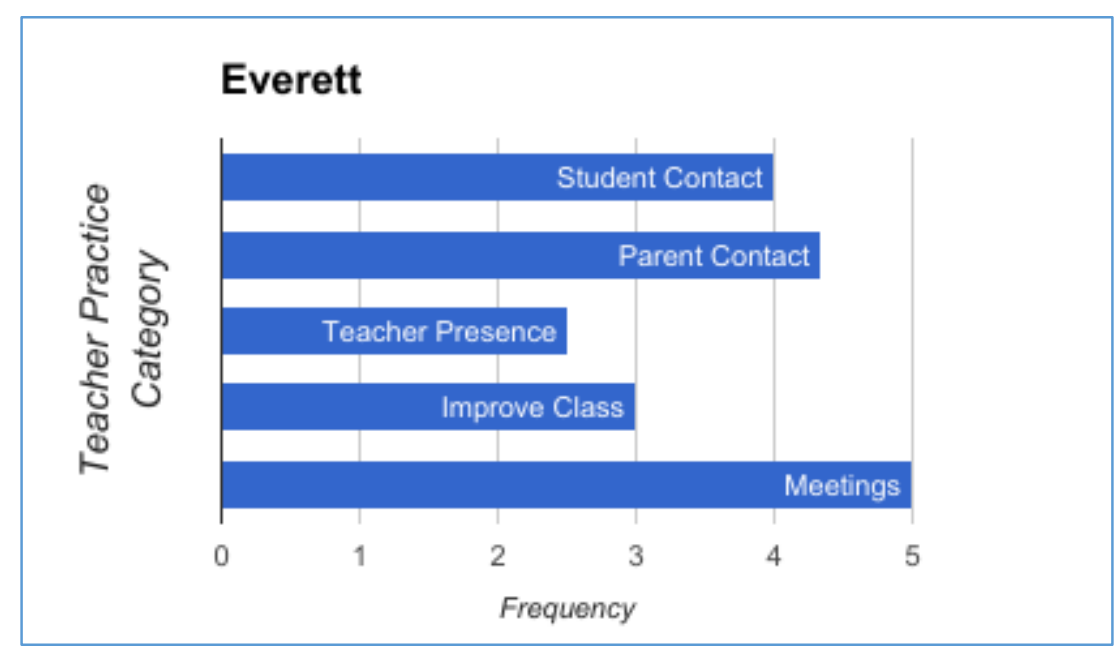

Everett reported working 65 hours per week for WES and spent only $20 \%$ of that time grading, which she completed within 48 hours of submission - although email 
response time was quicker, within 24 hours. She reported doing more things weekly than any other teacher, including: calling students, emailing parents, large group emails, meetings, virtual office hours, virtual organized lectures, and talking with students individually for DBA's. She also called parents and texted both students and parents 2-3 times per month. Once per month, she made videos of her class, checked in with mentees, and went through classes and contacted disengaged students. Everett only wrote new curriculum, made videos of herself, and ran specific physical labs once every couple of months, and she chose not to automatically allow retries on insufficient assignments. She did not answer the qualitative questions on the survey.

Table 9. Everett's Subject breakdown

\begin{tabular}{|ll|c|c|c|}
\hline & Everett & $\begin{array}{c}\text { Number of } \\
\text { Student data } \\
\text { points }\end{array}$ & Average A.B. \% & $\begin{array}{c}\text { Average Percent of } \\
\text { Students }>\mathbf{2 0 \%} \text { A.B. }\end{array}$ \\
\hline H.S. $\quad$ Math & 25 & $35.09 \%$ & $80.00 \%$ \\
\hline H.S. & Science & 486 & $29.61 \%$ & $50.66 \%$ \\
\hline
\end{tabular}

Everett added the math class in the second semester after a math teacher's sudden departure; as you can see, those students represent a small portion of her overall student responsibilities. Her science numbers are very solid, especially compared to the other science teacher, Barrentine, which indicates the serious problem that WES had: a near$52 \%$ failure rate is still in the top-half of teachers. 
Figure 7 - Corona's Teacher-action Distribution

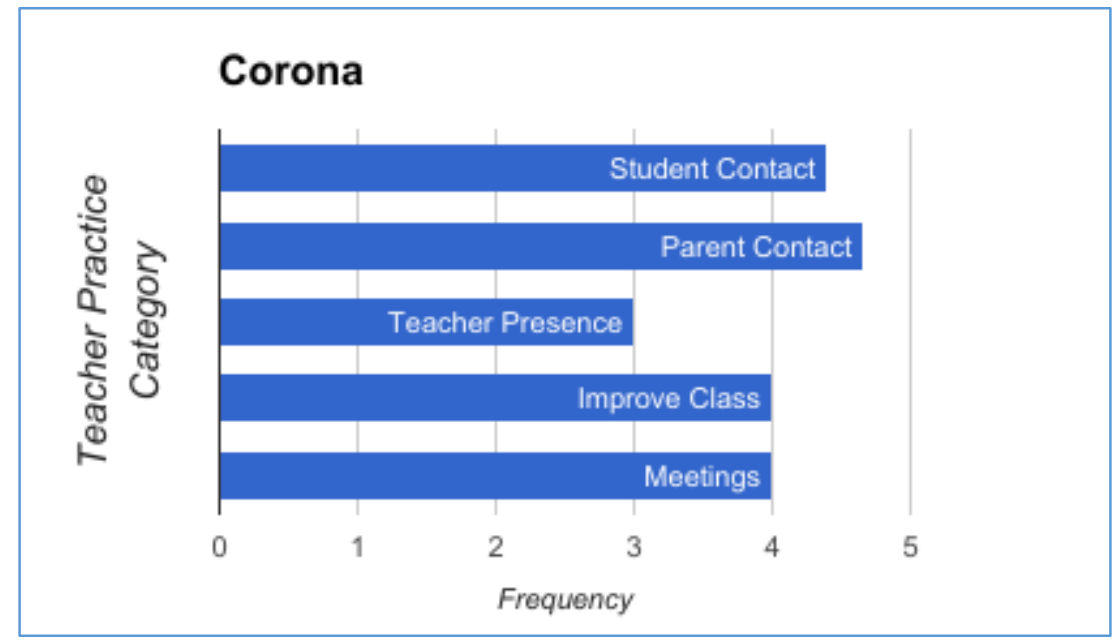

Corona reported spending $60 \%$ of her time on grading, but her assignments were graded within 48 hours, longer than most teachers. She emphasized quick communication though, getting back to student emails on the same day they were sent and reporting weekly communication via text, call, and email. She didn't text parents as much, or blog or make videos - her main emphasis was on contact with students. She used the DBA's for paper editing, and she did a lot of labs; Corona specifically mentioned using Adobe Connect (a video call software that allowed for screen sharing) to focus on specific assignments. She didn't meet as often with teachers, only 2-3 times per month rather than weekly, and she didn't always 'automatically allow retries' on assignments.

Table 10. Corona's Subject breakdown

\begin{tabular}{|ll|c|c|c|}
\hline & Corona & $\begin{array}{c}\text { Number of } \\
\text { Student data } \\
\text { points }\end{array}$ & Average A.B. \% & $\begin{array}{c}\text { Average Percent of } \\
\text { Students }>20 \% \text { A.B. }\end{array}$ \\
\hline H.S. $\quad$ English & 422 & $33.72 \%$ & $61.05 \%$ \\
\hline H.S. $\quad$ Economics & 66 & $30.77 \%$ & $55.22 \%$ \\
\hline
\end{tabular}


Now we're in the tier of teachers that had over $60 \%$ of their students who were very unlikely to finish the course. Corona's classes were mostly 9 th and 11 th grade basic English; 9th grade in particular is a tough year at any school, so some of her low numbers could be attributed to that.

Figure 8 - Diphily's Teacher-action Distribution

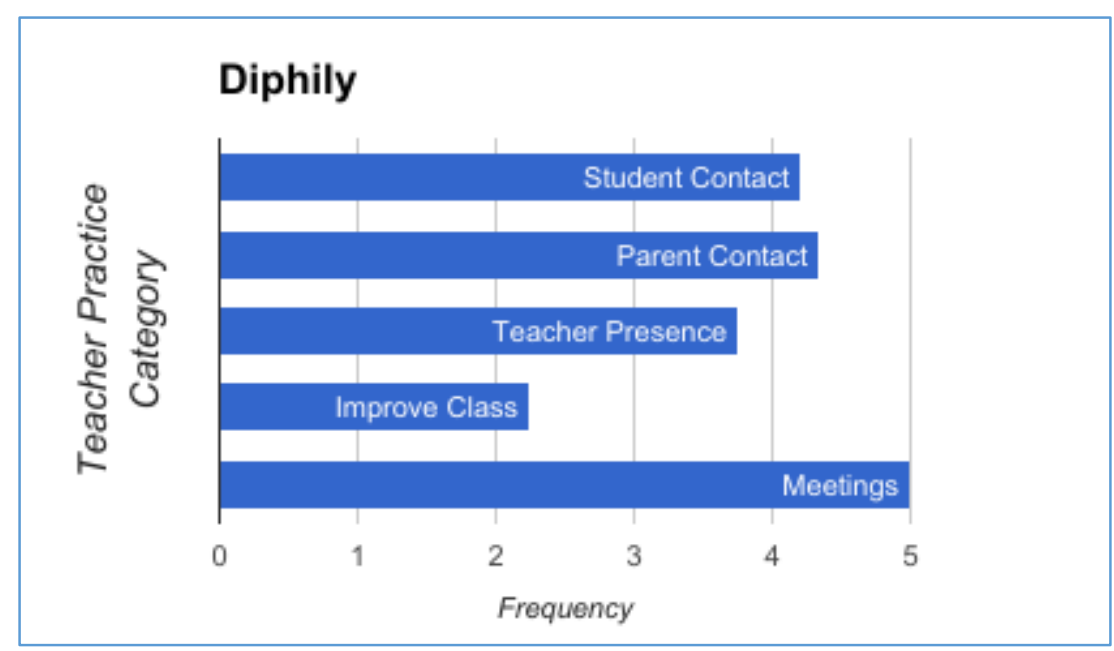

Diphily taught high school math. She had some of the most unique allotments of time, reporting $60 \%$ of her time spent grading but a 2-4 day time period to have assignments graded. She responded to student emails on the same day, but only used calling and texting 2-3 times per month (most teachers reported weekly use). She did email parents every week, along with sending out large group emails, checking in with mentees, and talking individually with students for DBA's. She also spent a lot of time in meetings and at the school, reporting "being on campus" as her 2nd most time-consuming duty, and she was in meetings with other teachers every week. 
Table 11. Diphily‘s Subject breakdown

\begin{tabular}{|l|c|c|c|}
\hline Diphily & $\begin{array}{c}\text { Number of } \\
\text { Student data } \\
\text { points }\end{array}$ & Average A.B. \% & $\begin{array}{c}\text { Average Percent of } \\
\text { Students }>\mathbf{2 0 \%} \text { A.B. }\end{array}$ \\
\hline H.S. Math & 424 & $35.32 \%$ & $61.50 \%$ \\
\hline M.S. Math & 43 & $15.13 \%$ & $30.13 \%$ \\
\hline
\end{tabular}

Some of Diphily's poor high school numbers can certainly be attributed to the difficulty of math, particularly since her middle school numbers are actually the best! Many students came to WES deficient in credits, particularly in math, so she was dealing with a tough segment of the population, and her classes were mostly Algebra 1 and Integrated Math which are both entry-level courses.

Figure 9 - Goudy's Teacher-action Distribution

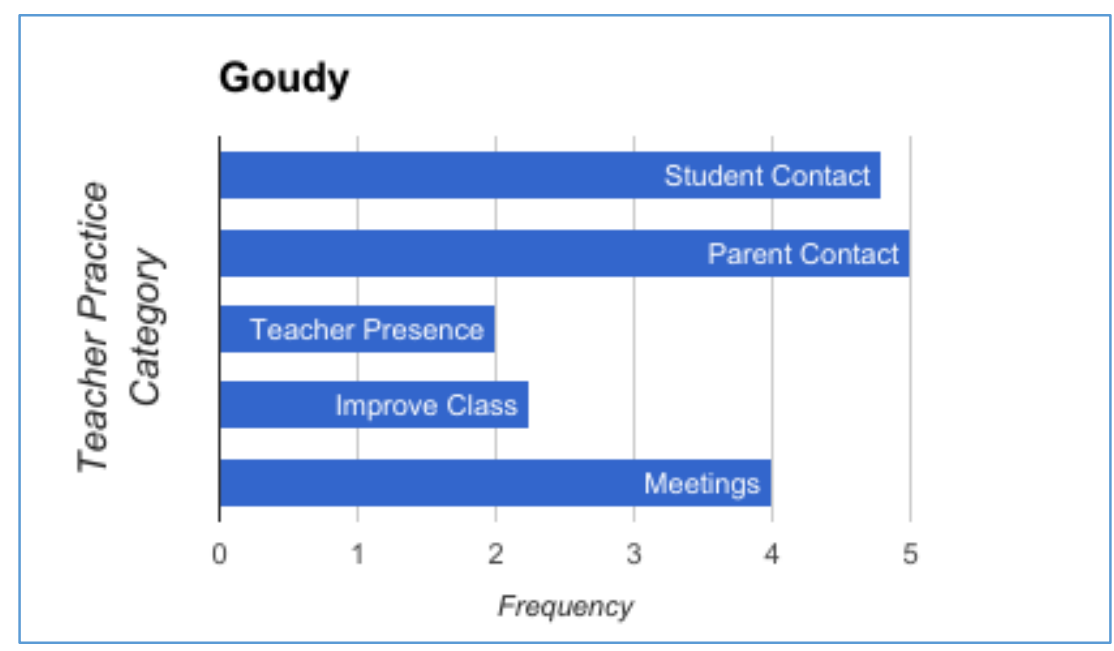

Goudy had the most varied prep-types at WES, covering keyboarding, middle school math, and Physical education. She spent $60 \%$ of her work hours grading, listing it as a particular emphasis. From her survey: 
"I am a fanatic about grading because I want to provide students with timely feedback on their assignments. This gives them 1) an incentive to work in my classes because they know where they stand and 2) they are able to correct their assignments sooner which helps them to master their content before developing habits that are more difficult to break (math)."

Goudy also heavily emphasized personal contact, reaching out weekly to both students and parents in every venue available. All of her top 3 motivating factors related to forging a relationship with students. She had a reputation at the school for being very no-nonsense; she's one of the few teachers who did not automatically allow retries on assignments and the only teacher to list 'engage with students about non-school topics' as a less-than-weekly behavior. Goudy had virtual office hours (expected by administration), but didn't participate in many of the other online-specific techniques, like blogging, virtual lectures, and videos; she did say she wished she had time to make videos and flip her classroom. Her meetings with other teachers were relatively less common that most, reporting only 2-3 times per month for both categories.

Table 12. Goudy's Subject breakdown

\begin{tabular}{|l|c|c|c|}
\hline \multicolumn{1}{|c|}{ Goudy } & $\begin{array}{c}\text { Number of } \\
\text { Student data } \\
\text { points }\end{array}$ & Average A.B. \% & $\begin{array}{c}\text { Average Percent of } \\
\text { Students }>20 \% \text { A.B. }\end{array}$ \\
\hline H.S. Math & 24 & $33.45 \%$ & $59.52 \%$ \\
\hline $\begin{array}{l}\text { H.S. Physical } \\
\text { Education }\end{array}$ & 174 & $37.63 \%$ & $63.08 \%$ \\
\hline M.S. Keyboarding & 81 & $21.23 \%$ & $36.59 \%$ \\
\hline M.S. Math & 103 & $18.76 \%$ & $33.21 \%$ \\
\hline
\end{tabular}


Goudy covered a lot of different areas; I left the high school keyboarding class out of her data because it had a very different format than other classes, and it was particularly self-directed since it required no teacher grading or DBA's. I left Middle School keyboarding here because that population is so uniform; every middle school student took the same 5 core classes and took keyboarding at least once. Her keyboarding numbers are lower than the middle school average, but because of the different format, I don't think we can blame Goudy for that. Her math numbers were right in the middle; her hands-on approach may have appealed more to middle school students.

Figure 10 - Barrentine's Teacher-action Distribution

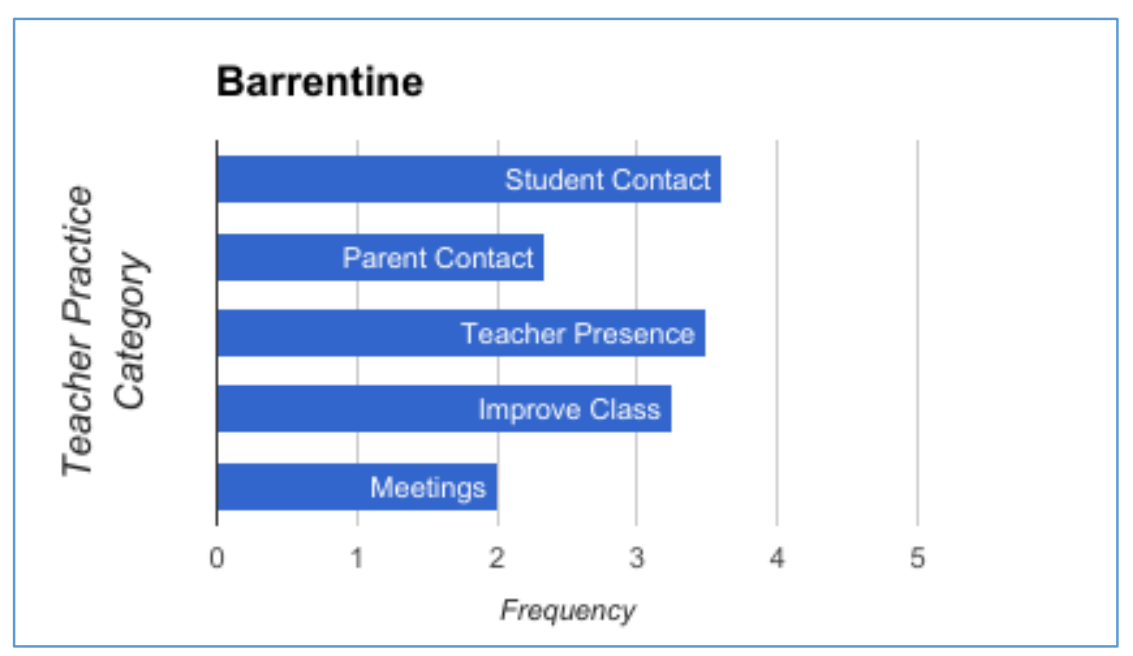

Barrentine, your researcher, was on a half-time teacher salary (0.5 FTE), so only 20 hours per week counted towards the practices studied here. I spent about $35 \%$ of my time grading, consistently returning work to students within 36 hours of their submission, and I checked email very regularly so that I could respond to most student emails the same day they were sent. My weekly practices included: texting students, virtual office hours, individual DBA discussions, updating a blog, and running specific lab 
opportunities. All my science classes had lab requirements, usually asking students to assemble some basic materials and use them to run experiments, so I would set up the science room with those materials and regularly promote the weekly opportunity to use them. I kept a consistent schedule and while students could work on anything during the time, I tried to have specific plans so that students would be inspired to come in and complete those assignments. I tried briefly to conduct virtual classes, but they were only attended by students who were already doing very well, so I moved away from that strategy.

I chose to begin blogging because I didn't know what to work on. My blog was a tangible product that administration could see, and I enjoyed taking current events and molding science lessons onto them, but I don't believe very many students were checking it and it certainly didn't help engage students who weren't engaging with the curriculum at all. The primary tangible benefit came when I inserted a blog post into the curriculum, but I rarely wrote assignments to accompany them so it was just extra information.

I knew the value of calling home, but I still didn't do it as often as I should have. I got into the habit of logging all my calls home, which was very helpful - once I had established contact with a parent, I could ask them about their responsiveness to texting, which I then used more regularly with those parents. The contact log showed that I was doing it less frequently than I thought, however, which is why I reported calling and emailing parents only once every couple of months, along with going through classes and contacting disengaged students - that process was something I always felt like I should be 
doing, but kept putting off. I didn't send off large group emails as often as other teachers, and I didn't think that emailing parents was very effective, so I avoided that as well.

My focuses tended toward improving the class experience; I wrote new curriculum at least once a month, and made videos of my class even more often - these tended to involve recording my screen while logged in as an example student while I narrated completing a particular assignment. I felt that these videos were great opportunities to teach the science concepts and the process at the same time, and I sometimes created Google Doc templates for the assignments as well that students could copy and fill in, so that the science itself could be the focus of the assignment, rather than formatting or other structural concerns. As I mentioned in the practices section, I spent almost no time in meetings with other teachers, despite having more physical in-school time due to my "Surf School” class.

My other responsibility at WES was "Surf School," our 'launch class' for new students, for which I was paid hourly. WES had new students every week and before this class, there was very little frontloaded training for new students beyond their initial meeting with a counselor. I designed a course that trained students in using Google Docs, which they used to submit all assignments, and other intricacies of the system. I also required students to use a template to create a resume and take a typing test with a screenshot of the results, and I referred weaker typists to our keyboarding classes. 
Table 13. Barrentine's Subject breakdown

\begin{tabular}{|l|c|c|c|}
\hline Barrentine & $\begin{array}{c}\text { Number of } \\
\text { Student data } \\
\text { points }\end{array}$ & Average A.B. \% & $\begin{array}{c}\text { Average Percent of } \\
\text { Students > 20\% A.B. }\end{array}$ \\
\hline H.S. $\quad$ Science & 214 & $39.02 \%$ & $64.76 \%$ \\
\hline M.S. $\quad$ Science & 206 & $20.40 \%$ & $32.21 \%$ \\
\hline
\end{tabular}

Your researcher had some pretty terrible numbers, which were part of the frustration that lead to this thesis. I did OK with middle school students; I had many of them in my gaming club, and a few came in regularly to work with me. My high school numbers are unacceptable, however, and they show that I was clearly not doing enough to keep students engaged.

\section{Teacher Rankings: Analyzing Practice Frequency}

In order to rank the teachers by effectiveness, I used the percentage of students more than $20 \%$ behind pace, as this indicated how many would fail to finish the course. Average-percent-behind numbers were skewed by students who had totally given up, whereas the percentage of students more than $20 \%$ behind pace more accurately measured the portion of students who were failing for that teacher because they weren't engaging in the course.

Once I ranked my teachers using the percentage of their students that were more than $20 \%$ behind pace, the data split nicely for high school, with four teachers under $46 \%$, Everett at $53 \%$, then the other four teachers over $60 \%$. Their overall average assignments-behind percentages would have resulted in slightly different rankings but the top four would remain the same, so my comparison of top four to bottom four wouldn't 
change. I decided to ignore Martin's information, however, because her high school classes were all art, which seemed unfair to compare to teachers of core, non-elective classes. The middle school teachers also split into distinct tiers as you can see in Table 4 .

I already had most of the teacher practice frequencies in a 1-5 system based on the teacher survey of practices, but I wanted to compare grading time and response time as well, so I gave the answers there a 1-5 designation using the system described in the methods section about Teacher Availability.

For high school, I averaged the frequency of each practice for the top four teachers (without including Martin in the rankings) and the bottom four teachers, then found the difference and sorted the practices in descending order. A bigger number means the more effective teachers performed the action more often. Negative numbers indicate that they were used more often by the less effective teachers.

Only Martin, Reed, Goudy, Diphily, and Barrentine taught middle school, so I averaged the top two and bottom two then calculated the difference; Goudy's data is not included in the middle school "best practice" rankings. I didn't include "Conducting virtual office hours" here because there was essentially no difference between teachers (only Cook didn't have weekly Virtual office hours). I also did not include the meeting items because they were pretty consistent between teachers and didn't directly affect student behavior. Each practice's color corresponds with its category, as seen in the key:

\begin{tabular}{|l|l|l|}
\cline { 2 - 3 } \multicolumn{1}{|l|}{ Table 14 Color Key } & $\begin{array}{l}\text { Individual Contact with } \\
\text { Students }\end{array}$ & Parent Contact \\
\hline Teacher Presence & $\begin{array}{l}\text { Improving Class } \\
\text { Experience }\end{array}$ & Teacher Availability \\
\hline
\end{tabular}


Table 14. Difference in Practice Frequency between top and bottom teachers

\begin{tabular}{|c|c|}
\hline $\begin{array}{l}\text { Average } \\
\text { difference }\end{array}$ & High School Rankings \\
\hline 1.00 & Update a blog for students \\
\hline 1.00 & $\begin{array}{l}\text { Conduct virtual organized } \\
\text { lectures or classes }\end{array}$ \\
\hline 0.50 & Make videos of yourself \\
\hline 0.50 & Make videos of your class \\
\hline 0.50 & $\begin{array}{l}\text { Grade work soon after its } \\
\text { turned in }\end{array}$ \\
\hline 0.25 & Email Parents \\
\hline-0.25 & Call students \\
\hline-0.25 & $\begin{array}{c}\text { Go through classes and contact } \\
\text { disengaged students }\end{array}$ \\
\hline-0.25 & Check in with mentees \\
\hline-0.25 & Text Parents \\
\hline-0.50 & Call Parents \\
\hline-0.50 & Write new curriculum \\
\hline-0.50 & Respond quickly to emails \\
\hline-0.75 & Text with students \\
\hline-1.00 & $\begin{array}{c}\text { Post announcements in } \\
\text { Brainhoney }\end{array}$ \\
\hline-1.25 & $\begin{array}{c}\text { Run a lab with a specific plan, } \\
\text { rather than open lab or office } \\
\text { hours }\end{array}$ \\
\hline-1.75 & $\begin{array}{c}\text { Talk with students individually } \\
\text { for Discussion-based } \\
\text { Assessments }\end{array}$ \\
\hline
\end{tabular}

\begin{tabular}{|c|c|}
\hline \begin{tabular}{|l} 
Average \\
difference
\end{tabular} & Middle School Rankings \\
\hline 1.50 & Make videos of yourself \\
\hline 1.50 & $\begin{array}{c}\text { Post announcements in } \\
\text { Brainhoney }\end{array}$ \\
\hline 1.50 & Update a blog for students \\
\hline 1.50 & Respond quickly to emails \\
\hline 1.00 & $\begin{array}{c}\text { Talk with students individually } \\
\text { for Discussion-based } \\
\text { Assessments }\end{array}$ \\
\hline 1.00 & Check in with mentees \\
\hline 1.00 & Text Parents \\
\hline 1.00 & $\begin{array}{c}\text { Run a lab with a specific plan, } \\
\text { rather than open lab or office } \\
\text { hours }\end{array}$ \\
\hline 1.00 & Make videos of your class \\
\hline 1.00 & $\begin{array}{c}\text { Grade work soon after its turned } \\
\text { in }\end{array}$ \\
\hline 0.50 & Text with students \\
\hline 0.50 & Call students \\
\hline 0.50 & Call Parents \\
\hline 0.00 & Write new curriculum \\
\hline-0.50 & $\begin{array}{c}\text { Go through classes and contact } \\
\text { disengaged students }\end{array}$ \\
\hline-0.50 & Email Parents \\
\hline-1.00 & $\begin{array}{l}\text { Conduct virtual organized } \\
\text { lectures or classes }\end{array}$ \\
\hline
\end{tabular}


The difference between these two rankings surprised me the most, as I had never adjusted my strategies between middle and high school, and I didn't hear other teachers suggest that much either. Based on this data, the practices and organization of classes for middle school students should be distinctive to emphasize the individual contact that seems better correlated with student success for middle schoolers. My interpretation of this data is that middle school students appreciate contact and interest a lot more, while high school students are more put off by teacher contact, possibly viewing it more like harassment than helping. Of the positive numbers for high school, only grading assignments quickly represented a direct student contact point, while more effective middle school teachers had higher numbers for: responding quickly, talking individually with students for DBA's, grading quickly, and both texting and calling students directly.

Overall, this data partially reflected my concern that motivated this thesis: most teacher actions do not seem to have a positive effect on student engagement, but that was only true for high school. The majority of practices there had negative numbers, which indicated that the less effective teachers were doing more, somehow. In middle school however, the better-performing teachers were using most the practices more often, which makes better sense and also aligns with my conclusion that middle school students benefit from more personal contact in their online classes.

\section{Teacher-side Summary}

After careful analysis of the whole school's assignments-behind data, I was able to rank the high school and middle school teachers separately by how well their students were engaging with the curriculum by completing assignments. Using those rankings and 
the teacher-practice survey data, I was able to compare the top tier of teachers with the bottom tier and find the practices that top tier teachers were doing more frequently. The high school and middle school 'top practices performed by more effective teachers' looked different from each other, most notably in the individual contact category; their similarities indicate practices that are good for all ages.

Effective practices for all ages:

- Making videos of yourself and your class

- Updating a blog

- Grade work soon after it's turned in

Practices more effective for high school students:

- Conducting virtual organized lectures or classes

- Emailing Parents (only slightly more common with more effective teachers) Some practices seem to discourage high school students since the less effective teachers did them much more frequently, particularly talking individually with students for DBA's, running a lab with a specific plan, and posting announcements in Brainhoney. These three lowest ranking practices for high schoolers are all used a whole level of frequency more often by more effective middle school teachers, which really exemplifies how different the strategies should be for students of different ages.

For middle school students, almost every practice was used more frequently by the more effective teachers except going through classes to contact disengaged students, emailing parents, and conducting virtual organized lectures or classes - all of those appear in the top half of the high school rankings. The top-ranked practices that are unique to middle schoolers include:

- Responding quickly to emails 
- Posting announcements in Brainhoney

- Talking with students individually for DBA's

- Texting and calling both parents and students

- Running a physical lab with a specific plan

\section{Student-side Study and Profiles}

With only 23 students responding to the affective variable survey and only three also completing the survey of teacher practices and relationship, this part of my study cannot draw many useful conclusions. Additionally, I didn’t ask nearly enough qualitative questions, so I cannot paint a full picture of who these students were and why they chose online school. Still, I will present the situation of these middle and high school students as best I can, starting with the first survey.

\section{Affective Variable Effect on Assignments Behind}

To analyze this relationship, I compared students' affective variable in math and science with their respective average 'assignments behind' number in those courses (data available in Appendix B-2). The overall affective variable for each subject is the average of the sub-categories, which themselves were averages of responses for 2-6 specific questions. Some of the questions were positive and others are negative, so I inverted the numbers ( 5 becomes 1, 4 becomes 2 , etc.) for the negative questions so that the affective variable average properly reflects the student's beliefs. I hypothesized that there would be a negative correlation here, because higher affective variables indicated a better opinion of oneself but higher 'assignments behind' indicated students who weren't engaging in the curriculum regularly. The data was not statistically significant for either category, but there is a small negative correlation, as represented by the 'best fit lines' of the data. 
Figure 11 - Math Affective Variable vs. Assignments Behind

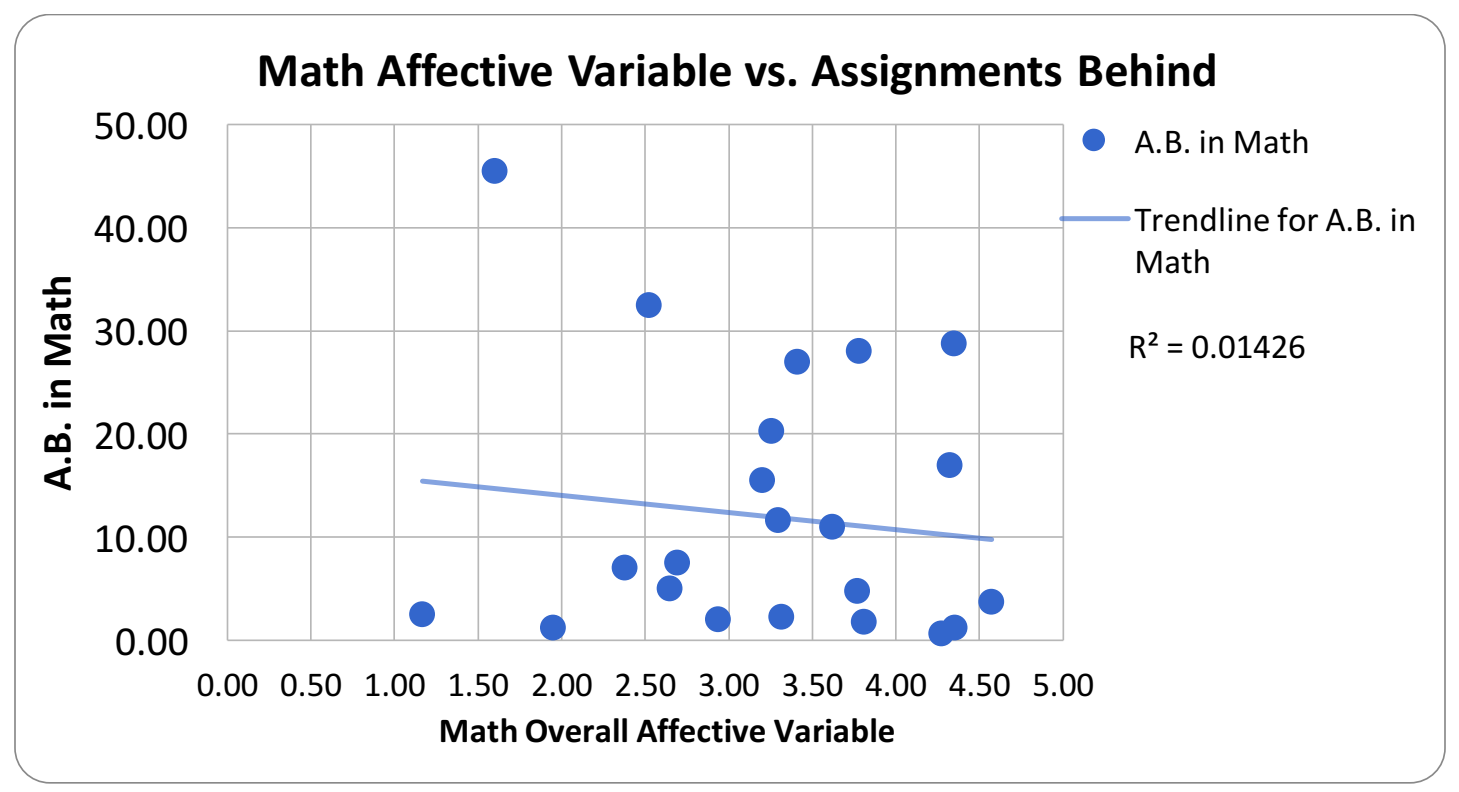

Figure 12 - Science Affective Variable vs. Assignments Behind

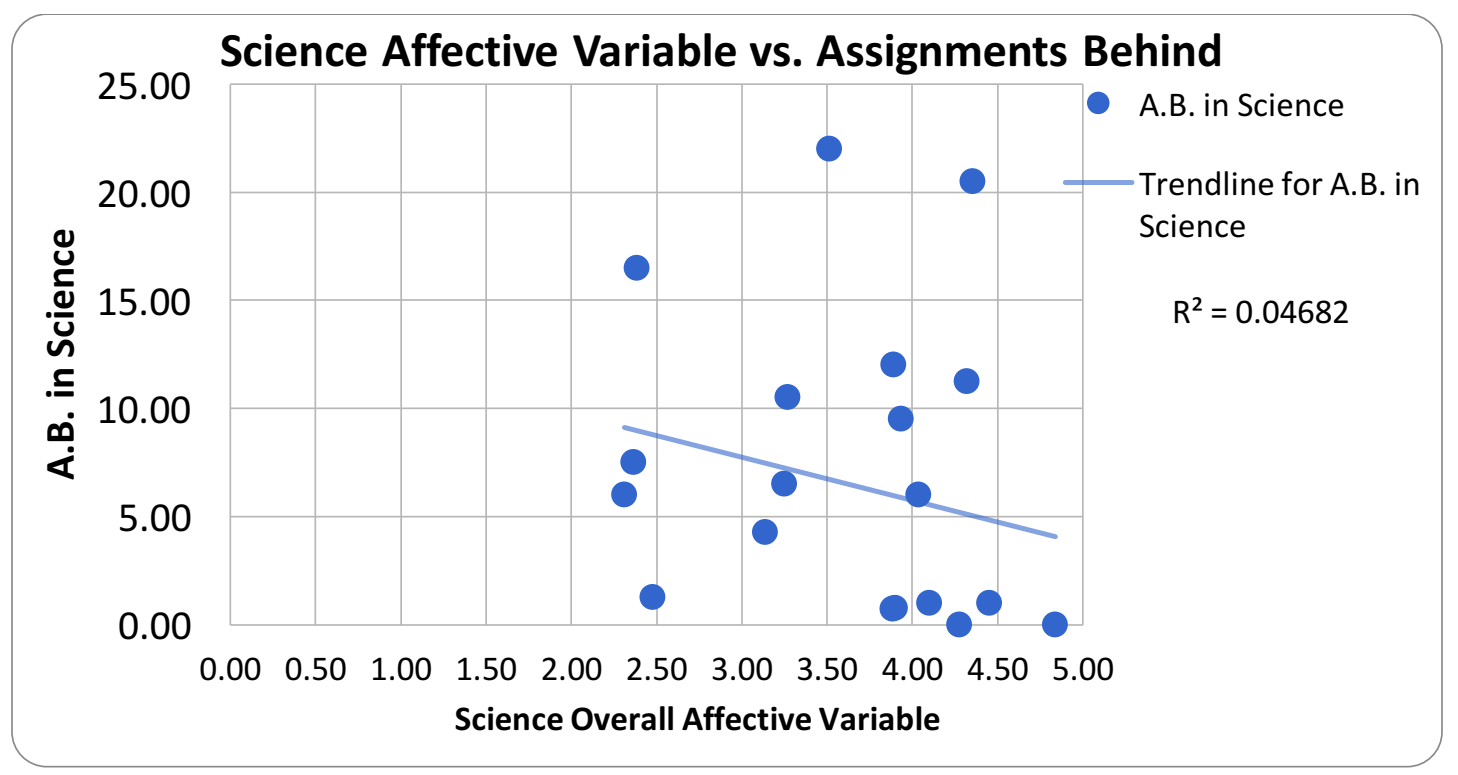

Breaking down the affective variable into its components (academic identity, relatedness, competence, autonomy, purpose, engagement, and resilience) gave some more interesting data, although none of it is statistically significant. Rather than using 
lines of best-fit and correlation data, I used a gap-analysis on the subcategories by sorting the students by their assignments behind in math and comparing the averages of the eleven best-performing students to the eleven worst-performing students. This chart shows the average difference in each component for the math affective variable:

Table 15. Math Affective Variable Gap Analysis

\begin{tabular}{|l|c|}
\hline \multicolumn{1}{|c|}{ Math } & Average Difference \\
\hline Relatedness & 0.18 \\
\hline Engagement & 0.16 \\
\hline Resilience & 0.11 \\
\hline Competence & 0.05 \\
\hline Purpose & -0.32 \\
\hline Identity & -0.36 \\
\hline Autonomy & -0.42 \\
\hline
\end{tabular}

Based on this data, the better-performing students had the expected higher marks only in relatedness, engagement, resilience, and competence. Lower-performing students actually scored themselves higher, by a much bigger margin, in purpose, identity, and autonomy, which is perhaps the most surprising because of the autonomous nature of online school. You can see the specific questions asked for each category in the survey in Appendix A-2 or the top row of the data in B-2. This data tells me that students have a very complicated relationship with math; the overall difference between top and bottom averages for the math affective variable is.- .02 , which means the two sections of students barely differed in their belief in their math abilities, despite averaging a difference of almost 20 A.B. in math classes.

The data makes a lot more sense when comparing the scientific affective variable to the number of assignments behind each student is in his or her science classes. I sorted 
the spreadsheet in the same way and found the difference between the averages of the top eleven students vs the bottom eleven students and every subcategory indicates a higher average for top-performing students.

Table 17. Science Affective Variable Gap Analysis

\begin{tabular}{|l|c|}
\hline \multicolumn{1}{|c|}{ Science } & Average Difference \\
\hline Relatedness & 0.40 \\
\hline Autonomy & 0.37 \\
\hline Identity & 0.36 \\
\hline Purpose & 0.36 \\
\hline Competence & 0.33 \\
\hline Resiliency & 0.26 \\
\hline Engagement & 0.18 \\
\hline
\end{tabular}

It's interesting that engagement, the very thing that A.B. is supposed to measure, has the lowest difference between the two ends of the spectrum. Students who believe that their life relates to science ("Relatedness") and do their work in science because they are personally interested (“Autonomy") tended to perform best in science classes according to this data. This data better supports my hypothesis that an initial survey could be a powerful way to predict student success in online courses. Overall, top performing students averaged 11.68 less assignments behind and had a .31 higher science affective variable.

I also compared the students' technology affective variable with their overall assignments behind, and here I did find a statistically-significant negative correlation, which means that a higher technology affective variable correlated with fewer assignments behind. This correlation passes the eye test: students who felt better about their technology skills were more effective in online school. 
Figure 13 - Technology Affective Variable vs. Average Assignments Behind

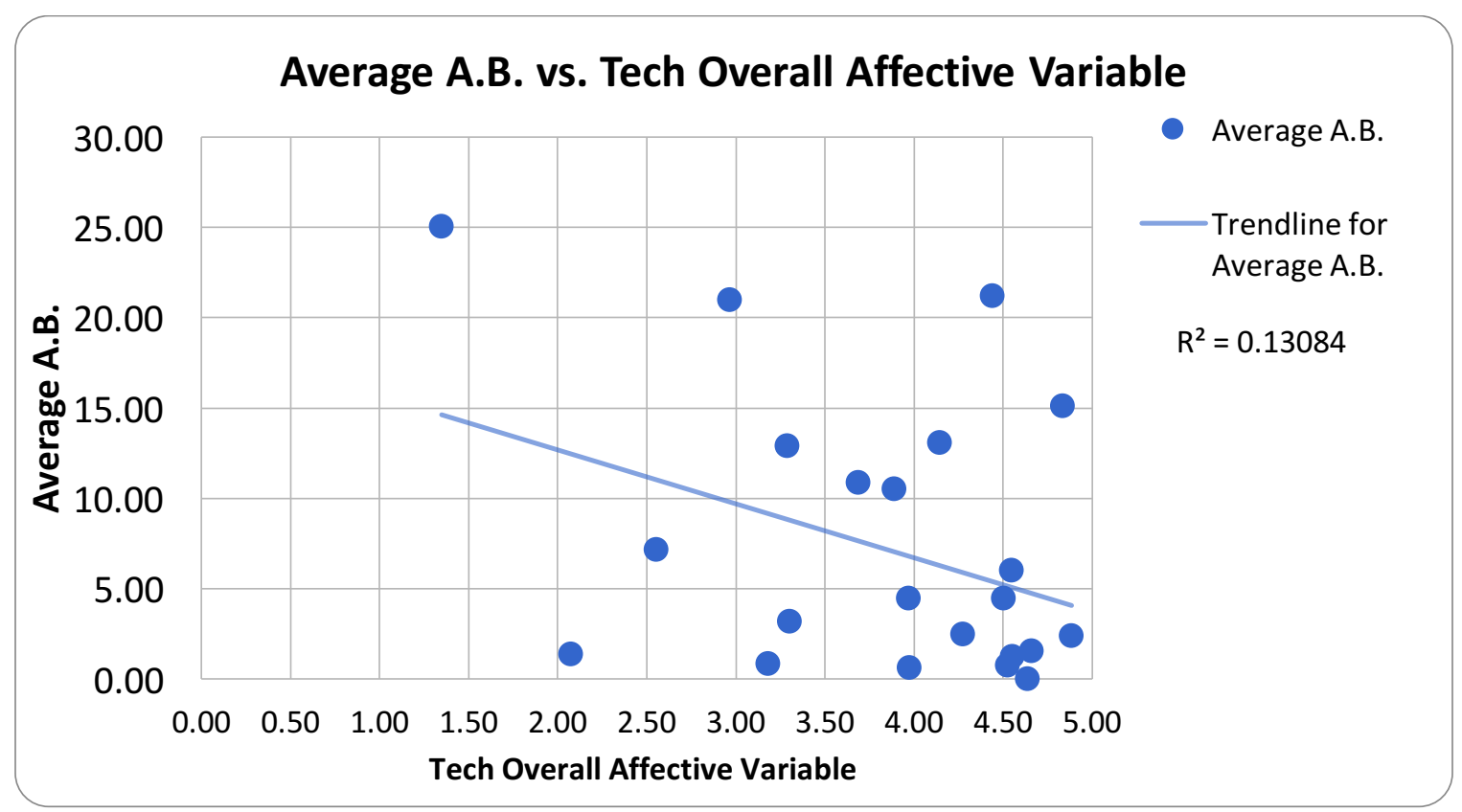

The technology affective variable survey only had four subcategories: resilience, identity, competence, and purpose. Using a regression analysis comparing the four subcategories to the students' overall average A.B. resulted in a $\mathrm{p}$ value of .0788 , which is close to the goal for statistical significance. The correlation was actually extremely positive for "identity" however, and slightly positive for resilience, which indicates that students who felt higher in those categories actually performed worse. Competence and purpose both had the expected negative correlations.

When I did a gap analysis on the Technology subcategories like I did with the Math and Science, however, I found that all four categories had higher averages amongst the top-performing students. Here's the difference between the top eleven and bottom eleven students for each of those subcategories: 
Table 18. Technology Affective Variable Gap Analysis

\begin{tabular}{|l|c|}
\hline \multicolumn{1}{|c|}{ Technology } & Average Difference \\
\hline Purpose & 0.64 \\
\hline Competence & 0.36 \\
\hline Resilience & 0.36 \\
\hline Identity & 0.32 \\
\hline
\end{tabular}

Identity and Resilience still had the lowest numbers using this form of data analysis, although the Competence category had the same difference as Resilience. The Purpose of Technology category showed the strongest difference of the entire study, but it was based on just two statements: "Technology is important for my future career" and "I don't see the point of learning technology," which was inverted to form this average. 19 of the 23 students chose "Not at all true" for the second statement, so the biggest difference in this category is whether or not students agreed with the idea that "Technology is important for my future career."

I also wanted to compare middle school and high school students using the Affective Variable Survey, so I averaged each category for the eight middle school students and the fifteen high school students who participated and calculated the difference. All the way across the board, middle school students averaged higher Affective Variable numbers and less assignments behind. The A.B. data mirrors the whole-school analysis which showed that middle school students averaged far fewer assignments behind. 


\section{Student Survey of Motivational Practices}

Because I only had three students (all high schoolers) answer this survey (data in Appendix B-3), I will use it to case-study those students, using all the data already discussed in this paper in addition to their answers about teacher practices and their relationship with their math and science teacher. There were only two instances of "This discourages me," both from the same student and about me, so the first lesson (backed up by the research) is that students are generally motivated by the feeling of teacher presence in their online courses, no matter what method is used (Azaiza 2011, Dennis et al. 2007, de la Varre et al. 2014).

Student Zz22 must have been attending WES in addition to another school, because she only had two classes each semester, Algebra 2 (A and B) and US Government/Economics, and she listed a science teacher who doesn't work for WES in her survey. WES had a few partnerships like that, most notably with the magnet school across the street, so that students could earn online credits for certain classes while pursuing other interests. Zz22 averaged 2.5 assignments behind in both of her classes, which means she almost certainly finished the semester on time. Her affective variable for math was 3.78 , seventh highest amongst the 23 students surveyed, and she reported a 4.28 affective variable in Technology, which is in the top half. She had a different math teacher in the first semester and averaged fewer assignments-behind than with Diphily, who was her teacher during this study. (Her teacher during the first semester is the only teacher at WES not included in this study because he left halfway through the school year before surveys were sent out.) 
Zz22 reported being most motivated by Diphily's quick email responses, availability during lab times and specific course-times both physical and virtual, and quick grading. She averaged high marks (4+) in every Student-Teacher Relationship category except the curriculum-specific “Authentic Academic Work,” which fell way lower at a 2.75 , indicating frustration with the curriculum but not with Diphily.

Student Zz18, a sophomore, also had Diphily for math (Geometry B) in the second semester after the same un-studied math teacher for Geometry A in the first semester. Zz18 didn't respond to any practices with "This really motivates me," but gave a "This motivates me" designation to the same "available during physical/virtual lab times" and running specific courses and virtual lectures categories as Zz22. His "My teacher doesn't do this" choices told the better story here, agreeing with Zz22 that Diphily did not text or call parents. He agreed that emails were motivating but Diphily did not "quickly answer emails" or "grade within 2 days;" Diphily's teacher survey reported a more than two-day turnaround time for grading but same-day response to emails.

Zz18 also reported that Diphily didn't: use encouraging language while grading, ask about his personal life, or improve the class experience with personalized curriculum, templates, or videos. He suggested that calling him, contacting him when he hadn't been working, and posting announcements in Brainhoney were all things Diphily did, but they did not motivate him. Interestingly, he said the same thing (teacher does it but it doesn't motivate him) about the following categories for his science teacher: "grades within a day," "automatically allows retrys," "makes a template for an assignment," "schedules a 
meeting in person," and "asks about [his] personal life." Zz18's answers throughout had internal consistency within the survey questions, indicating that he really considered each element of this survey, as they all seem to make sense within an overall theme. His scores on the Teacher-Student relationship survey further indicated that he had a problem with Diphily, averaging a "Not at all true" score of 2.0 for both the Teacher Engagement and Communication categories; he gave scores averaging 5 and 4.4 for those categories for his science teacher.

Zz18 had a much better relationship with his science teachers, but he had me in the first semester and Everett in the second, which is when this survey was taken - since he listed both teachers, we can't really assign any of the teacher practices to either one specifically. Still, he was motivated by all of the Individual Contact category, as well as the teacher presence in lab availability and the improving of the class with personalized curriculum and specific labs and virtual lectures. He was also motivated by the use of encouraging language when grading assignments.

Zz18 was a very well-engaged student, averaging less than one assignment behind in all four measurement times, with five classes in each semester. His Math (3.32), Science (3.89), and Technology (3.18) affective variables were all close to the median score amongst the 23 participants, reflecting the lack of statistically-significant correlations between those variables and the assignments-behind dependent variable. Looking more closely, his highest ratings in both math and science were in competence, engagement, and resilience; Zz22's highest marks in the math affective variable category also included competence and resilience. 
Student Zz08, a freshman, portrays a very different situation from Zz18 and Zz22; he was significantly behind in all of his classes and very likely earned almost no credit during his year at WES. His Affective Variable averages were all in the bottom three of the 23 students studied, and after doing almost no work in Geometry A during the first semester, he did not have a math class second semester. He also doesn't have a science course listed for 2 nd semester, but he answered the survey for me, Barrentine, who was his first semester teacher in Physical Science A.

Zz08 reported being motivated by all the Individual and Parent contact elements, as well as quick grading times. The rest of the "teacher presence" and "improving class experience" categories are all either "my teacher doesn't do this" or "this doesn't motivate me" - except reporting discouragement when the teacher updates a blog or schedules a meeting in person. The Teacher-Student survey indicates that Zz08 believes in his teacher's involvement, engagement, and communication, but gives lower marks for structure, autonomy support, and the curriculum-specific "Authentic Academic Work" category. The lack of consistent narrative in Zz08's answers seemed like a strong indicator that he gave about the same attention to this survey as he did for his classes: very little.

\section{Student-side Summary}

The affective surveys yielded only one significant result: students who felt better about their technology skills were more effective in online school. With respect to the student motivational survey, a few of the answers from this small study align with our overall results. Both math students were motivated by Diphily's availability during 
physical/virtual 'office hours' and the specific courses and virtual lectures she ran; 'virtual office hours' didn't appear on our ranked practices list because it had almost zero variation between teachers, but running specific courses was one of our top-ranked high school strategies. The two students were also both motivated by fast email response times, although one student said Diphily wasn’t fast enough. Neither reported being motivated by Diphily reaching out via text, email, or phone call, which aligns with our conclusions about high schoolers shying away from those practices, although student Zz18 was motivated by individual contact from his science teachers, Barrentine and Everett. Zz08 was our youngest and least-engaged of the three students, and he also reported being motivated by individual contact. 


\section{Discussion}

This study was undertaken to determine the relative effectiveness of a variety of teaching practices at the West Excellence School. Following are the answers to the research questions.

\section{1) How do teachers at an online school allocate their instructional time?}

Time is a teacher's most precious resource; in traditional education, most of a teacher's time is regulated by scheduled classes, which come with deadlines for lesson preparation and graded items. Online school has much more independence, both for teacher and student, so self-regulation is crucial to success (Wang, Shannon, and Ross 2007). Time is also a zero-sum game: time spent on one practice means another isn't as available. The overall organization of the online class can be shaped by the teacher to help prioritize the right elements; for example, if a teacher plans to be super responsive with emails, he or she should use any customizable area of the curriculum possible to encourage students to reach out and use encouraging, understanding language in responses so that students feel welcome to contact again in the future (Dennis et al, 2007).

Much of this thesis covered how teachers are spending their time, so I hope the reader has a clear picture of what teaching at an online school can be like. What wasn't clear to me, as a new online teacher, was how much I needed to choose an overall strategy, rather than try to do everything for a little bit at a time. Individual contact, for example, likely works best when it's repeated, but that would mean sacrificing time spent on improving the curriculum; conversely, if I wanted to write new curriculum, I would 
need to design my class so that individual contact wasn't as regular for most of my students. Teacher presence would still be crucial, however, as we will see in the discussion of the next part of my research question.

\section{2) What instructional strategies are more commonly used by effective teachers at an online school?}

My data agreed with the literature review: teacher presence is the primary factor for student success in online school (Azaiza 2011, Dennis et al. 2007, de la Varre et al. 2014). In this thesis, we saw a variety of ways to insert 'teacher presence,' even outside the practices that I assigned to that category. I have a lot of evidence promoting the use of videos for all ages (Murphy et al, 2014), both of the teacher for motivational purposes and recorded by the teacher to help students with content. Teachers should have low grading turnaround time, as that gives students direct evidence that their teacher is paying attention and there are conceptual understanding benefits to immediate feedback as well. Responding quickly to student inquiries seems important as well, particularly for middle schoolers, but constant email checking has to be balanced with the rest of the responsibilities in a way the teacher can manage.

My data does not give any clear story on the best method of contact (text, call, or email) or whether students or parents are better to target initially. The correct method and person to contact when a student needs encouragement is likely very dependent on the student and should be differentiated as much as the teacher is able. I found a student/parent contact log very useful in both my online and traditional school experiences; teachers could organize that log by preferred method of communication. 
Another aspect that I've barely touched on is the hybridized environment that WES offers, with a physical building and open lab times for students to work. Anecdotally, only a small portion of the students used the building regularly, but it was crucial for initial meetings and my "Surf School" class for new students that introduced them to the style and procedures of online school. The only teacher practice I studied that related to the physical building was "Run a lab with a specific plan, rather than open lab or office hours" and it appeared second-highest for middle schoolers and second-lowest for high schoolers; again we see here the individual attention difference preferences between the two age groups.

Now let's look individually at each practice category, drawing conclusions based on the data and standard deviations and contrasting the middle and high school rankings:

Individual Contact with students. These practices almost all sit in the middle of both rankings in Table 14, which makes sense: they didn't have much variation between all of the teachers studied. The middle of the high school rankings, however, consists of mostly negative numbers, meaning less-effective teachers did them more often, whereas those practices are all strongly positive in the middle school rankings. I believe high school students required a gentler touch with the frequency of communications because they could start to feel very harassed, particularly if many of their teachers are sending out messages every week.

My data does not show any strong differences between email, text, and calling; again, with the low variance of these categories, the data doesn't tell us as much. 
“Talking with students individually for DBA's" barely slipped into the top half of standard deviations, and it was one of the most differently-ranked practices between middle and high school teachers: successful middle school teachers averaged a full level of frequency higher for that question than the unsuccessful teachers, but that trait was at the other end of the spectrum for high school teachers. Time is ultimately a zero-sum game for teachers: time spent on one aspect of teaching meant less time on others; a class organization that required talking individually for DBA's meant a lot of time dedicated to that practice. I appreciated DBA time because it was a great opportunity to reinforce the most important content, but because it required students to reach out, it certainly didn't help disengaged students, and it was quite time-consuming for me. My data suggests that teachers should replace DBA's for high schoolers with organized virtual classes that students can earn credit for attending, and the alternative (and thus lesser-used option) could be scheduling a DBA with the teacher.

Going through classes and contacting disengaged students was surprisingly negative for both middle and high school. Since the metric for these rankings was the number of students more than $20 \%$ behind in each course for each teacher, successfully re-engaging even a few students seems like it would make a tangible difference in that number. This is something that I feel like every teacher knew they should be doing, but it required setting time aside without distractions. We so rarely called with good news that the process could be emotionally draining, so it was difficult to motivate myself to do more frequently. However, the more successful teachers were actually doing it less; I'm not sure what to make of that exactly. 
“Checking in with mentees" perhaps shouldn't be included in the high school rankings at all because mentees were not necessarily in that teacher's classes because mentor groups were intended to be consistent year-after-year. Mentee groups weren't even separated by age so many groups had the full range of grades, which made group meetings a little less useful or interesting for students. However, new middle schoolers were put with middle school teachers, so the "contacting mentees" practice's high ranking actually does indicate that mentor relationships could improve classroom engagement. The position of mentor was still not fully fleshed out by WES when I left the school, but most teachers agreed that having a teacher in a caregiving position without grading important work should be a great resource for students. Other teachers seemed to resent their mentor group, as it took time away from their more measurable classes, particularly when administration began holding regular individual meetings assessing teacher success.

Parent contact. The effectiveness of emailing parents was very different between my middle and high school data, appearing as one of the few positives in high school and one of the few negatives in middle school. I'm sure students disliked having their parents contacted, but it could still be motivating. Which communication method to use (text, call, or email) is still unclear from this data, so I would say that teachers should try all of them and then communicate differently with parents depending on the platform that works for them. 
Teacher Presence. What an interesting category! Three of the four practices were in the higher variance half of Table 2 , which ranked the practices by standard deviation, while conducting virtual office hours was unanimously practiced weekly by every teacher except Cook. The three varied practices are also in the top three more frequently used by successful middle school teachers.

"Posting announcements in Brainhoney" seemed pretty inconsequential to me since it's just another method of communication, but it's high ranking for middle school teachers and low ranking for high school is another argument in favor of my strongest conclusion in this thesis: middle school students seem to be more inspired by teacher contact while high school students could be demotivated by it.

“Making Videos of Yourself' appeared high on both lists, which aligns with the emphasis on teacher presence that the literature suggests. As far as I know, no teachers used these self-videos to cover content; they were primarily motivating tools that gave students more connection to their teachers. Five of the teachers, including myself, attended a conference about online education, and quick, motivational self-videos were emphasized repeatedly. Khan Academy has been very effectively using videos for years, and schools are starting to integrate their online environment into the classroom (Murphy et al, 2014). YouTube is also full of "celebrities" who "vlog" (video blog), speaking directly into the camera about their lives, and these are very popular with the youngest generation.

High school's top-ranked "Updating a blog” practice is slightly misleading in both categories, because only two teachers did that regularly: high school's second- 
highest-ranked Howell and bottom-ranked Barrentine. Top-half high school teachers Reed, Cook, and Everett all had one, infrequently updated, which to me makes it more of a repository for occasional links/announcements than a real blog. We can derive some information from the content of the blogs, however: Howell's blog was a video of himself with some announcements and motivation, intended to build rapport and put a face with the class, whereas my blog was science-based and took a decent chunk of time to keep updated. In the middle school rankings, only Barrentine updated a blog regularly and I landed in the top half, so that data point is skewed as well.

Improving Class Experience. In some ways, this category overlaps with 'Teacher Presence,' but it's differentiated by the focus on the class rather than the teacher or the teacher-student relationship. The stark difference between the middle and high school rankings is most pronounced by the "Conducting virtual organized classes or lectures" question, at the top of high school practices and the bottom of middle school. "Running a lab with a specific plan" had the inverted difference with much lower scoring for high schoolers. In my experience, middle school students were much more willing to come into the building. That physical-presence difference aligns with my hypothesis about middle school students preferring direct connections, although they apparently didn't engage with scheduled virtual classes, which were pretty impersonal.

"Making videos of your class" was a very cool practice that I believe embodies the future "best practice" educational strategies, which is backed up by its high ranking for both middle and high schoolers. I wanted to make more lecture-style videos, explaining particular concepts, but I never did - the FLVS lessons were generally pretty 
instructive, so those videos would have been extra work for students and it was hard enough to get them to complete what we had. If I had written new curriculum or replaced assignments with my own, video lectures would have been common, with assignments following them, but as far as I know, no teachers did that. The year after leaving WES, I worked at a traditional school teaching physics and I made highly successful KhanAcademy-style videos of myself working through test reviews, partially because of my experience with online school. This type of video allows teachers to train students with direct teaching that's still flexible for the student because he or she can skip around and re-watch portions that are still confusing, all while the teacher models proper thinking strategies with the narration. Modern students love videos.

"Writing new curriculum" didn’t score very well in either category, which makes sense to me even though administration thought that might be a big part of the future for WES. The FLVS curriculum was very graphically-involved, with clarifying buttons, interactive games, and information un-intimidatingly split between pages. Teachercreated curriculum could not reach that graphic level at all; it was more often a published Google Doc full of information. The English teachers reported writing new curriculum every week, but nobody else did it more often than once a month, so it's hard to decipher its motivating effect.

Teacher Availability. Administration certainly believed that quick grading time was crucial to student success, and my lit review (de la Varre, C. et al., 2014) agrees with my data here: quick grading was very positive, tying for second-highest ranked in both middle and high school. Responding quickly to emails was tied for the top-ranked middle 
school practice, which again supports the individual contact preferences of middle schoolers. I'm surprised that it was low-ranked for high schoolers, although it wasn't nearly as negatively represented as other practices. Like talking with students individually for DBA's, responding quickly to emails requires a pretty significant time dedication for the benefit of only one student at a time. My data indicates that high school teachers should de-emphasize one-on-one communications in favor of class improvements and other generally-beneficial practices, while middle school teachers should still be maintaining personal connections as much as possible.

\section{3) How do students' subject-specific affective variables correlate with their success in math and science courses?}

My only statistically-significant conclusion for this category was that a student's higher technology affective variable correlated with their engagement in online school. A student's belief in the purpose of technology and their own competence with it both correlated strongly with how on pace they were in their classes. I don't think anyone needed research to conclude that students who struggle with technology will have greater difficulties engaging with online school, but my data supports it anyway!

The confusion around math's affective variable numbers seems to me an accurate representation of students' difficulty with math. Even students who have positive attitudes toward math might fail online courses just as often, according to my scant evidence. Science showed the expected higher engagement correlating with higher affective variable numbers, but I'm not sure how teachers could effectively use that general piece of information. 
Another angle on using the affective variable might be in grading: students who have very low affective variable scores should probably be handled with a much softer touch, as their confidence needs nurturing. On the flip side, students with high affective variables should be challenged more frequently, perhaps even given alternative assignments that allow them to skip busy-work if they can prove their understanding.

\section{4) What are the differences between middle and high school students regarding the} answers to research questions two and three?

The difference between middle and high school students came up time and again during this analysis, and because of the very different practice rankings, they were inextricable from my discussion on most effective practices. My strongest conclusion in this thesis is that the younger students are more motivated by individual contact. As I've mentioned before, our middle school students at WES were a lot more motivated and interested in school; their across-the-board higher averages in Affective Variable and lower averages in Assignments Behind supports that claim. More middle school students seemed to come to WES because it represented an alternative path, whereas for many of our high school students this was their last chance. Based on my data, high school teachers should lower the priority of individual contact in favor of inserting teacher presence using more general means, like videos, blogs, or virtual classes. Middle school teachers should maintain those individual contacts to the extent that they are able, although they are constrained by the same total time availability; fortunately, we can conclude that virtual classes and new curriculum are likely unnecessary for middle schoolers. 


\section{Connections to Literature}

The importance of quick grading that I found in my data matched one of the most important factors that de la Varre et al (2014) found in their work on reasons for student dropout in an online course; Anthony Artino and Andri Ioannou (2008) also promoted prompt feedback as a key to successful online teaching. DiPietro et al (2008) emphasized teacher practices that establish presence in the course. My data agrees that those have a high correlation with successful teachers. Strategies they described as motivational included: using varied strategies to connect with students including discussing noncontent topics, providing diverse lines of communication, and being prompt with feedback, all of which my data agreed with.

The article "Best Practices in Cyberspace: Motivating the Online Learner," by Toni Bellon and Richard Oates (2002) was the study I found that most closely matched my research, although they studied graduate-level students and their practices don't all align with the ones I studied. Still, they said emails from the teacher and public posts (like posting announcements to Brainhoney) were the most motivating factors, which my data agreed with, but only for middle school students. They said that having targeted due dates with flexibility was the third-most motivating factor, which WES had - that's where the assignments behind data came from!

\section{Limitations}

My dependent variable has a multitude of problems, not the least of which is that it didn't at all measure how effective a teacher was at teaching the material. Discussionbased assessments were a great example of that as they appeared to be a poor use of 
teacher time (for high school) but they were one of the few opportunities for teachers to stress the important issues and speak directly with a student who wasn't being helped by others to produce answers.

Access to the whole-school data was absolutely crucial to the validity of my teacher rankings; my rankings were based only on the 23 students who answered the first survey looked quite different. To draw solid conclusions about the effect of the affective variables, I would definitely want more student survey data, and of course I wish more than three students had responded to the second survey. Fortunately, student answers to both surveys were internally consistent, meaning each student chose opposite ends of the spectrum for positive and negative questions, which indicated to me that they read the questions and gave thoughtful answers. The affective variable and teacher-student relationship surveys also have validity because I adapted peer-reviewed surveys that have been accepted by the educational community.

My teacher survey was quite effective and I believe all the teachers who completed it gave thoughtful answers; some teachers did not finish the short-answer parts, however. I'm sure teachers suffered some recency-bias in their responses (the survey almost required it by asking questions in the present tense), so my second semester assignments-behind data is probably better aligned with the practices, but I used all four data points (two from each semester) in my averages because that better encapsulates effectiveness of the teacher rather than the single group of students that is present in one semester's data. To establish reliability, I should have sent this survey out earlier in the year and then again a few months later, because I'm sure teachers had 
recency-bias on the frequency of their actions. I do have some internal validity from the consistency of the responses for each teacher, which suggests that they read the questions before answering.

Any person's mood during a survey could affect the reliability of their answers, and I would think that effect would be heightened by a survey about the participant's belief in their own attributes. A pre/post affective survey would give a second data point, however that would more show how participation in online school affects the affective variable which is outside the scope of this study. The difference in conclusions between the two data analysis methods used on the Technology Affective Variable hurts the veracity of my overall study, further showing how much more work needs to be done to accurately study students of online school. Students are likely not reliable in their answers to what motivates them, because they might very well hate a particular practice (like when their parents are called) and thus be unwilling to admit that it motivates them. Students could easily be affected by recency-bias as well, further eroding the reliability of this section - which was already pretty low since I only had three students respond to it!

To find each teacher's overall average A.B. and average percentage of students who were more than $20 \%$ A.B., I adjusted the data based on the number of assignments in each class, but when I averaged all of each teacher's classes I did not use a weighted average based on number of students in each class. Still, the distinctly-tiered percentage differences between teachers (particularly in high school) means that even being $4-5 \%$ off (very unlikely) for a teacher wouldn't change my conclusions about the practices more commonly enacted by higher-performing teachers. 
I could also compare the teachers' engagement numbers to their overall subject, but the subject percentages are of limited use because they're comprised of (usually) just the two teachers on that subject - so I could use them to compare which of those two teachers were getting better results, but otherwise the conclusions are rather circular. Diphily's students might be performing low partially because she isn't motivating them, but perhaps math would be the least-engaging class no matter who was teaching it.

\section{Recommendations for Teaching at an Online School:}

Prospective or new online teachers face an intimidating learning curve to adopt a strategy and find their online voice for upcoming online classes. First, new teachers will have to take stock of their situation, including the ages of their students, the specific classes they'll be teaching and how many distinct classes they'll have, and the administrative expectations for grading, student contact, technology use and day-to-day operations. Helping the online teacher prioritize his or her time was the purpose of this thesis, so I have organized a few of my evidence-based recommendations in this section, starting with my ideas for an initial survey for students and then organized by my overall categories: Individual Contact, Parent Contact, Teacher Presence, Improving Class Experience, Teacher Availability, and Meetings.

Initial Survey(s). In "My Ideal Online School” section, I will discuss an initial survey that I think online schools should adopt to counsel new and prospective students about whether online school is the right fit for them. I also think teachers should survey their students when they begin a new online class to build a profile about each student, so the proper resources can be utilized to promote the success of that student. This survey 
could ask students about their preferred communications methods, interests, relationship with parents or guardians, educational history, and even some subject-specific questions to investigate the student's prior knowledge base. Math and Science teachers could also incorporate the Affective Variable survey (Appendix A-2) for their subject and use the results to differentiate their contact; all communications with students should be respectful and use encouraging language (Azaiza 2011, Dennis et al. 2007, Artino and Ioannou, 2008), but the Affective Variable could help teachers decide how specific to be with their grading and feedback. Another survey could also be sent to the students' parents, asking about the schedules of both parents and the student, preferred communications methods, and other general information. I encourage incorporating questions about non-school topics in these surveys, both to make them more fun and to build that ever-important student-teacher relationship (DiPietro et al, 2008).

Individual Contact. My data did not indicate a best method (call, text, or email) for contact, but I think that's appropriate because each student has different resources and habits; the initial survey I discussed in the previous section would go a long way towards deciding which method to use for different students. Individual Contact does seem more effective for younger students (middle schoolers in this study) while older students can be less motivated or potentially de-motivated by it. Reaching out to students will often be awkward at first, but communications should ease as both teacher and student grow more comfortable in the relationship, particularly if teachers are hyper-aware of their tone in written communications. The expectations for student contact will have to be welldescribed at the start of each class; I recommend a syllabus and a required intro video. 
The video could combine the teacher's face and screen-recorded video of the curriculum inside the learning management system to introduce students to the teacher, course, and expectations - and you'll want to be as friendly and encouraging as possible with this first impression.

Parent Contact. The value and preferred methods of Parent Contact also have limited conclusions in this thesis, but again the reality is likely based too much on the individuals involved to draw general conclusions. An initial survey for parents, sent by the teacher at the start of the course, could go a long way to deciding the best method for each student. I highly encourage a school-wide system for logging communication to avoid both students going un-contacted for long periods and students feeling overlyharassed by too-frequent contact. If the school doesn't have such a system, a simple Google Sheet or Excel spreadsheet can be very effective for logging contact, using Find in Page (keyboard shortcut 'Control + F,' an invaluable tool that I used many times a day) to take notes on the proper line whenever a student or parent called or texted me. When I used this method, I included the name and preferred method of communication for the more-involved parent/guardian, and a date and a few notes about each contact time - reviewing this right before calling home gave me crucial context for that interaction.

Teacher Presence. As our most varied, flexible, and impactful category, your philosophy on 'Teacher Presence' should be established early and then adapted constantly. 'Making Videos of Yourself' was the top-ranked middle school practice and tied for second more-frequently-used by effective high school teachers, so that practice is 
almost certainly effective. Making these videos can be intimidating and awkward at first as you try to talk to directly to your computer without any real-time feedback, but if you put on your acting face and push through, you can connect your face to the course for all of your students with less than thirty minutes of work. Mistakes in these videos are not a big deal in my experience. Sometimes you might restart if you mess up badly, but the occasional 'uhm' or uncertainty might even ingratiate yourselves to the students; remember, you should be aligning yourself on the side of the student to help support their work on the course as a facilitator, not establishing yourself as a formidable authority figure (Dennis et al, 2007).

'Updating a blog' also appeared highly on both ranked lists of practices used by more effective teachers, but as I suggested in the Discussion of this category, we can't be sure of how strong that conclusion is because I was both one of the most prolific bloggers and the least effective high school teacher. Blogging still took the top ranking for high school because of infrequent blogging by most of the effective teachers and the other three bottom-half teachers (besides myself) choosing "that's not my style" for that practice. If blogging fits your style, however, it's likely an effective way to establish 'Teacher Presence,' although I would caution that it's very difficult to be general enough to fit all of your classes if you have a lot of distinct courses to teach unless it's purely a motivational blog. The time requirements of your school matter here as well: if students are all required to be on the same pace, your blog can be very relevant to what students are currently working on. If students are all at different points and you have just a few classes, you could have class-specific blogs that review material they should have 
reached, link to relevant current events, and tease upcoming units. If your school is like WES, however, a new full-time teacher would have around ten different classes of students that should be moving through the curriculum at roughly the same pace, but they aren't because there's no penalty for late assignments. In that case, both time-based and class-specific blogs were impractical, so I made my science blog about general scientific knowledge based on current events and other links/videos that I found, and Howell (who taught Social Studies) made his blog purely motivational and technology-based.

'Posting Announcements in Brainhoney' might not be relevant to your curriculum, but it's interesting to note that this extra method of general communication was far more effective for middle schoolers than high schoolers. Most learning management systems probably have something equivalent to this, and teachers should likely decide whether they will use it regularly or not very early in the semester and then stay consistent through that semester.

'Virtual Office Hours' had almost no variation between teachers (every teacher had them weekly except Cook who didn't offer them at all), so we haven't looked at that practice since the Results section, but I would recommend that online teachers have some version of these. 'Virtual office hours' represent regularly scheduled availability times we used a chat room link that was the same every week, but just promising to be on Google Hangouts or another instant messaging system during that time would have a similar effect. I regularly reminded students and parents of these times during communications to encourage time management skills and give students some structure for their personal scheduling: "If you work on science from 1-3pm tomorrow, I'll be 
available online to almost instantly answer any questions you might have" (me, commonly).

Improving Class Experience. Each of the practices in this category involved making the class more accessible for students. Making videos once again ranks highly here, but this question asked specifically about videos of the class, meaning explanation videos for sections of the curriculum. Videos like that could be combined with videos of the teacher for motivational purposes or explaining a specific concept. Again, starting these videos can be intimidating and awkward, and extra care is needed to prepare what's open on your screen for recording. To make these videos, I frequently used a 'test student' login so the curriculum would look the same as it does for students, which required IT support, and I had a similar 'test student' Gmail account so that my emails and Drive files wouldn't appear in any videos (even briefly). These videos require more editing, particularly if you're including videos of yourself as well, and you'll likely have to restart the recording a few times at the beginning before you get comfortable with the process.

Writing new curriculum is another area where the results are hard to interpret, as it was done with equal frequency by the top and bottom-ranked middle school teachers and more often by bottom-ranked high school teachers. If you choose to write new curriculum, I think extra resources are necessary for maximum effectiveness, specifically assistance with graphic design and web development to improve the look and usability for students. One of the only new curriculums that I would write would be large projects that could replace tests or even whole units of smaller assignments. These projects could 
have naturally-occurring investigative points that require students to find out about other concepts. One great example from the Patterns Physics curriculum that I taught at traditional school was a Texting While Driving project that asked students how far away somebody had to be in the road for you not to hit them if you looked down at your phone. To answer this question, students needed to study the basic relationship between distance and time (velocity), design experiments to see how long it took to read and send texts, understand the relationship between distance and time while stopping (acceleration), and finally write conclusions based on evidence about the differences in stopping time if you check or send a text while driving. Adapting that project for online school could result in just a few pages of new curriculum, but they would be filled with links to outside resources and requirements for smaller assignments to be completed over the course of a few weeks. Similar projects could be created for any topic area, with starting questions like "What job would I have had as a colonialist in 1770's America?" or "What are the most likely ways that I could die?"

My questions on running labs or organized classes gave us another clear difference between middle and high school students: physical labs were more popular with effective middle school teachers, while virtual labs worked for high school teachers, and both practices fell at the bottom of the other list. Your initial survey could help ascertain the interest level for your students in the two options, but the organization of your school will dictate a lot of your choice here. As I mentioned in the Treatment section, only my already-on-pace students participated in these, so I moved away from them; perhaps if they were consistent, they would eventually motivate students by giving 
them a time to work on your specific subject, but virtual or physical office hours are a more flexible option if students are not moving through the curriculum at similar paces.

Teacher Availability. As we've discussed, this category has only two practices: how quickly teachers responded to emails and graded assignments after the student hit submit. Same-day grading of assignments should be your top priority, along with email responses (Lim and Kim 2003, de la Varre et al. 2014, Artino and Ioannou 2008, DiPietro et al 2008), but email response in particular can be difficult to balance with other responsibilities because it is so reactive. I recommend that teachers be very honest with themselves about what typical email turnaround time will be and then advertise that to their students to set proper expectations. For grading, the results are pretty definitive: even if you don't like it, returning assignments with proper feedback as quickly as possible to students is crucial.

Meetings. I have not discussed meetings since the results section because almost every teacher reported extremely regular participation in meetings, so there were no conclusions to draw about that practice. I'm mentioning it here to give my recommendations, which in this case are based on my experience and opinion, not evidence. While blowing off steam is necessary in education, I think teachers should be more aware of how unproductive meetings are if they only identify problems without discussing solutions. I also think online schools should heavily emphasize the sharing of teacher practices in meetings so that other teachers can learn the efficient tricks, timesaving techniques, and engaging practices that teachers are finding success with. Howell 
mentioned teacher collaboration on practices as the thing he wished he had more time for in the qualitative part of the Teacher Survey of Practices (Appendix B-1).

\section{My Ideal Online School:}

Based on my research, experience, and data analysis, I have a few ideas on what an online school should look like. I would start with the organizational language: we wouldn't have teachers at online school, but facilitators (Dennis et al, 2007), and our mission statement would involve befriending our students to encourage engagement. Facilitators need to remove themselves from an 'authority position' in some ways so they can subtly align themselves on the same side as the students, working together towards the common goal of each student's education through completion of online courses. The course (and its content) should be the obstacle, while the facilitator is there to support the students, rather than the teacher being positioned as the gatekeeper for whether a student passes or not. That philosophy should promote proper phrasing of feedback and responses to questions, so that facilitators are always encouraging better understanding rather than pointing out errors.

Because of the impracticality of teachers creating online curriculum, I would likely purchase a curriculum like WES did, although I would try to find a newer, less popular curriculum because of the issues we had with plagiarism and the availability of most test answers online. If we did want to create the curriculum, much of that work would have to be done before we enrolled students, and the school would need a dedicated web developer and graphic designer with a well-organized ticketing system for the creation of items. Our curriculum would take more advantage of the online 
environment with more open-ended assignments and choice; for example, I would love to see over-arching projects that encourage exploration of specific content as it comes up in the problem-solving process, and curriculum-embedded important statements that are surrounded by possible questions that students could click on for more information. The curriculum would need to involve authentic work on relevant topics and be modifiable so it could be updated each year with current events and resources (Dennis et al. 2007, Artino and Ioannou 2008, Lim and Kim 2003).

Regardless of the source of our curriculum, facilitator presence would be all over each course, mostly in the form of videos for both motivational and educational purposes. Other features that I would like to see in our online curriculum include:

- Formative quizzes that have pop-up explanations when wrong answers are selected; sometimes that pop-up could be the facilitator explaining the misconception

- Motivational 'high-five' graphics after students complete long or difficult assignments, preferably by that facilitator: these videos could serve as both teacher presence and immediate feedback even if the item hasn't been graded yet

- Grade-specific strategies that work with that age range, so that students are gradually given more independence and less direct contact as they grow

- Game-based rewards for completion of assignments and courses, which I didn't study in this thesis because no teachers were attempting it

I believe that WES had the right idea with the hybridized environment, but my data suggests that that's only necessary for middle school students. I informally spoke with a teacher from another online school that has no physical building, but mentors visit all of their students every two weeks to work with them and establish motivational relationships, which is one way to have a hybridized environment without an expensive 
building. Mentor groups were also under-studied in this paper, so I'm not sure how I would organize those. Mentor groups can either be with the same teacher year-after-year or the mentees can also be in those teachers' classes; I see the merits of both systems, but they are incompatible with each other. Staff meetings at my online school would focus on teacher practices, asking each teacher on a rotating schedule to share tricks of the trade that they've learned.

In my new online school, the factors I've discussed should lessen the high failure rate that WES experienced, but I still haven't discussed the students themselves. The nature of traditional school makes transferring back out of online school an arduous and often ineffective possibility, so I would try to enroll students who have a reasonable chance of being successful in the online environment. I would develop an initial survey for prospective students that assesses the student's experience, affective variable, motivation, and preferred learning styles; intelligence, content knowledge, and current grades are not part of this assessment. The results of this survey would be used to counsel students about whether online school is the right fit for them and provide individualized support structures; if the school were big enough, entry-survey data could even be used to place students with teachers who use their preferred learning style(s).

While I have no actual plans to start an online school, I do want to add an online component to an existing curriculum, specifically Patterns Physics, which began in Beaverton a few years ago and is now being adopted by both Portland and Hillsboro school districts (Hill, 2013). Much like the way Khan Academy has been used by schools (Murphy et al, 2014), my online environment for Patterns Physics would emphasize 
choice and tutoring, to be used in conjunction with teachers in traditional learning environments. I would use my online school experience to make videos that are connected to learning targets and write a blog that connects the material to current events and other relevant resources. Formative quizzes could lead into specific tutorials for missed questions, and for every test I would provide a review packet with a video of myself completing it, modeling proper scientific thought processes and critical thinking skills throughout. My website would concentrate on the two ends of the spectrum: providing detailed tutorials of crucial concepts for struggling students, and open-ended, application-of-knowledge projects for advanced students or as alternative assignments that teachers could assign to make up failed tests. Especially after this research, I imagine my 'Help with Patterns Physics' website would have a significant injection of myself into it, so I would likely share personal stories alongside science in my blogs or even podcasts, which is another tool I would like to see explored more in education. With the proper development resources (meaning at least one dedicated website designer, plus a collection of teachers who would like to collaborate), we could offer Physics-specific problem sets that give immediate feedback and link students to help for the areas they missed (Murphy et al, 2014). Curriculum-specific help websites like this that cross district lines could pool resources and achieve the quality necessary for engaging, selfdirected online curriculum that allows teachers to easily differentiate their classrooms and support students on their level. 


\section{Suggestions for Further Research}

Following are two broad suggestions for further research: recreating this methodology in other online schools and conducting a full experiment in an online school. I recommend that other studies only require one survey, as so few of my students answered both. Additionally, I only compared middle school students to high school students, but there are a plethora of other comparative analyses that would contribute significantly to our understanding of the online environment.

Recreating this Methodology. The surveys I developed and adapted could be modified for any online school to analyze the teachers' priorities and find that school's most effective practices (as long as assignments-behind data or something like it was available), all without the difficult process of getting students to answer a survey. If a school did want to survey their students, I would recommend a single survey that asks about why they chose online school, how their previous school experience was, and then the first half of my Student Survey of Motivational Practices, modified with the actions taken by teachers at that school. The affective variable and teacher relationship data, while interesting, likely wouldn't be of practical use school-wide. Teachers could individually assign the affective variable survey at the beginning of the course so they can properly communicate with students based on their self-efficacy. The teacher relationship data would be useful mid-semester or as an end-of-course survey to help improve their own practices for the next semester.

In addition to the factors discussed in the Limitations section, I was also frustrated during data analysis by the questions that I didn't ask. A better survey about what 
practices motivate students should ask students for some anecdotal information, like completing the sentence "I'm most motivated when my teacher..." or asking "What do you wish your teachers would do more often?"

Another reason to administer a student survey would be to determine which students might be at risk for failing. Such a survey would be given when students first enroll and would ask qualitative questions about why they are enrolling in online school, their previous school experience, and their working routines. Accumulating this data could paint a better picture of successful (and unsuccessful) online students so that students who are at risk could be identified early and provided with additional counseling and other supports.

My teacher survey gave me some great data, but future surveys should ask teachers more about their previous experience with online school. Teacher interviews would be very helpful as well. Unfortunately, all of the math and science teachers at WES declined a follow-up interview; perhaps I should have asked teachers personally after data had been collected for that permission, instead of on the initial survey. A survey question asking teachers to rank their priorities on a smaller list of more generalized strategies would also provide great data. I'd also like to see future studies include the grades that students earned in each teacher's class, so that teacher effectiveness could be a factor, rather than the simple engagement that I studied here.

Experimenting on Online School. A full experiment using my results would involve teachers choosing a specific focus for their energy and priorities and then comparing their engagement numbers to either previous years' or other teachers' 
statistics. For example, a few teachers (hopefully volunteers) could dedicate themselves to video creation for a semester, and the researcher could compare the resulting numbers to that teacher's numbers from the previous semester or to the teachers who didn't emphasize the theorized 'best practices' discovered in this thesis. I would also like to see teachers organize their classes differently based on the ages of their students, emphasizing individual contact for younger students, and a researcher could analyze the results of that shift in focus.

\section{Conclusion}

I set out to find the most effective online strategies, but because of the complex interactions, there likely isn't one best set of practices. We have discovered that teaching strategies should likely be different between middle and high school students, and we have seen great evidence promoting the use of video for all ages. As with traditional teaching, variation in teacher practices will help reach the most students. Every online school will be different in technical ways based on the curriculum, learning management system, and administrative expectations, but many of my conclusions are general enough to apply to most online situations, and this methodology could be used to find the more effective practices for any online population. As online schools continue to open and the education system deals with the necessary fundamental changes the internet and other developments have forced upon them, many more investigations into online environments will be necessary in the coming years. 


\section{References}

Artino, A. J. (2008). Promoting academic motivation and self-regulation: Practical guidelines for online instructors. Techtrends: Linking Research And Practice To Improve Learning, 52(3), 37-45.

Azaiza, K. (2011). Learners' motivation in a distance education environment. Distance Learning, 8(1), 23+.

Bellon, T., \& Oates, R. (2002). Best practices in cyberspace: Motivating the online learner. Paper presented at the NECC. http://confreg.uoregon.edu/necc2002

Dennis, K., Bunkowski, L. \& Eskey, M. (2007). The little engine that could--How to start the motor? Motivating the online student. InSight: A Collection of Faculty Scholarship, 2, 37-49.

DiPietro, M., Ferdig, R.E., Preston, M. \& Black, E.W. (2008). Best practices in teaching K-12 online: Lessons learned from Michigan Virtual School teachers. Paper submitted to the Journal of Interactive Online Learning.

Hill, B. (2013). The patterns approach: Engaging freshmen in the practices of science. Science Teacher, 80(3), 38-42.

Lim, D. H., \& Kim, H. (2002-2003). Motivation and learner characteristics affecting online learning and learning application. J. Educational Technology Systems, $31(4), 423-439$.

Murphy, R., Gallagher, L., Krumm, A., Mislevy, J., and Hafter, A. (2014). Research on the use of Khan Academy in schools. SRI International. Retrieved from https://www.sri.com/work/publications/research-use-khan-academy-schools 
ODE Report Card Download. 2015-2016 school year. Retrieved from http://www.ode.state.or.us/data/reportcard/reports.aspx

Saxton, E., Bruns, R., Holveck, S., Kelley, S., Prince, D., Rigelman, N., \& Skinner, E. A. (2014). A common measurement system for k-12 STEM education: Adopting an educational evaluation methodology that elevates theoretical foundations and systems thinking. Studies in Educational Evaluation, 40, 18-35.

de la Varre, C., Irvin, M. J., Jordan, A. W., Hannum, W. H., \& Farmer, T. W. (2014). Reasons for student dropout in an online course in a rural K-12 setting. Distance Education, 35(3), 324-344. doi: 10.1080/01587919.2015.955259

Wang, C., Shannon, D. M., \& Ross, M. E. (2013). Students' characteristics, selfregulated learning, technology self-efficacy, and course outcomes in online learning. Distance Learning, 34(3), 302-323. 


\section{Appendix A: Survey Instruments}

\section{A-1: Teacher Survey of Practices}

1. Do you consent to having this information used in a research paper? All you'll have to do is complete this survey. It will not be anonymous - I'll be using the results of this survey to write a survey for students asking how motivational they find each of the strategies you employ. My faculty advisor at PSU, Melissa Potter, will also see your names but otherwise you will not be identified to anyone. You can contact Melissa at (503) 3299686 or by email at mepotter@pdx.edu, and I can be reached at (971) 231-5428 or barrentine@mewebacademy.org. After the semester is over, l'll be asking a few of you to be interviewed by me about your process and practices here at WES. Your participation is voluntary and you can stop at any time - just let me know, and l'll remove you from the data set. Your information will be completely de-identified in the final paper and only the practices will be discussed, unless you agree to be interviewed. Even then, I will not use your name and the discussion should be general enough to prevent identification by others.

2. Please acknowledge by entering your name that you understand that this data will be used for research purposes and professional development, but it is non-evaluative. The risks are minimal and do not go beyond the normal course of business here at WES.

3. Roughly how many hours do you spend per week on work for WES?

4. Roughly what percentage of your time spent is on grading?

5. What would you say is your average time to have assignments graded?
a. Same Day
b. Within 24 Hours
c. Within 36 Hours
d. Within 48 Hours
e. 2-4 days

6. How quickly (on average) do you respond to students' emails?
a. Within a couple of hours
b. Same Day
c. Within 24 Hours
d. Within 36 Hours
e. Within 48 Hours
f. 2-4 days

7. Please fill out the following grid based on roughly how often you use these strategies: Options: "That's not my style," "Once every couple of months," "Once a month," "2-3 times per month," "Weekly."
a. Text with students
b. Call students
c. Call parents 
d. Text Parents

e. Email parents

f. Go through classes and contact disengaged students

g. Post announcements in Brainhoney

h. Write new curriculum

i. Make videos of yourself

j. Make videos of your class

k. Send out large group emails

I. Check in with mentees

$\mathrm{m}$. Meet with other teachers as part of an assigned (or volunteered) committee (i.e. curriculum committee)

n. Meet with other teachers to collaborate on practices, strategies, or curriculum

o. Run a lab with a specific plan, rather than open lab or office hours

p. Conduct virtual office hours

q. Conduct virtual organized lectures or classes

r. Talk with students individually for Discussion-based Assessments

s. Update a blog for students

t. Automatically allow retrys on insufficient assignments

u. Engage with students about non-school topics

8. Is there anything not listed above that you do at least semi-regularly?

9. Besides grading, what do you spend the most time doing, and roughly how long (or percentage) of your time do you spend doing it?

10. What's your next biggest time investment, and how long do you spend doing it?

11. What's the number 1 thing you wish you had more time to do?

12. Is there something that you're doing that seems uncommon or unique among teachers at WES?

13. What do you think are the top 3 things teachers can do to motivate students? (please limit answers to things teachers can control, not student characteristics)

14. How many students do you have? (Not including Mentees in Mentor Seminar)

15. How many different classes (preps) do you have in a semester?

16. How do you use student feedback to change your practices? 


\section{A-2: Student Affective Variable}

Assent Question: This survey was written by Scott Barrentine, Science teacher and New Student Coordinator, for a research study for his master's thesis at Portland State University (PSU). Your information will be analyzed and coded by a faculty advisor at PSU so that none of the teachers at WES, including Mr. Barrentine, will see your answers or even know whether or not you chose to participate. Do you assent to Mr. Barrentine using your answers to this survey and your data on how many 'assignments behind' you are in your classes in his research study? The results will all be averaged and anonymous, so there will be no way for you to be identified.

Please answer all of the following questions based on this scale:

\section{ANSWER RESPONSE SCALE}

\begin{tabular}{|c|c|c|c|c|}
\hline $\begin{array}{c}\text { Not at all true } \\
1\end{array}$ & A little bit true & Somewhat true & Fairly true & Totally true \\
\hline
\end{tabular}

- The +/- column is for data analysis: positive questions are scored normally while negative questions are inverted.

- I did not include some of the drill questions but l'm leaving them here because they are part of the original survey (Saxton et al, 2014). I labelled "Drill-Used" all the drill questions that I chose to include, and any questions I added for the online environment are labelled with the word "Online."

Table A-1. Math:

\begin{tabular}{|r|l|l|}
\hline IDENTITY & & \\
\hline Core & I am the kind of person who can succeed in Math. & + \\
\hline Core & I want to be in a Math-related career when I grow up. & + \\
\hline Core & People like me do not get jobs in Math. & - \\
\hline Core & Math doesn't have anything to do with my life. & - \\
\hline Relatedness & & \\
\hline Core & Math class is a good place for students like me. & + \\
\hline Core & Sometimes I feel like I don't belong in Math. & - \\
\hline Competence & & \\
\hline
\end{tabular}




\begin{tabular}{|r|l|c|}
\hline Core & I am good at Math. & + \\
\hline Core & I don't have the brains to do well in Math. & - \\
\hline Drill & I can do well in Math if I want to. & + \\
\hline Drill & If I decide to learn something hard in Math, I can do it. & + \\
\hline Drill & I can't get good grades in Math, no matter what I do. & - \\
\hline Drill & I am not very good at Math. & - \\
\hline Autonomy & & \\
\hline Core & $\begin{array}{l}\text { I do my work in Math because it is personally important to } \\
\text { me. }\end{array}$ & + \\
\hline Core & I do my work in Math because they make us do it. & - \\
\hline Online & $\begin{array}{l}\text { I do my work in Math because I want to do well for my } \\
\text { teacher }\end{array}$ & - \\
\hline Purpose & & \\
\hline Core & I believe that Math can help make the world a better place. & + \\
\hline Core & Math is important for my future career. & + \\
\hline Core & I don't see the point of anything we are learning in Math. & - \\
\hline Core & There's no reason to learn Math. & - \\
\hline
\end{tabular}

\begin{tabular}{|r|l|l|}
\hline Engagement & & \\
\hline Core & I try hard to do well in Math. & + \\
\hline Core & When we work on something in Math, it's pretty interesting. & + \\
\hline Core & I look forward to working on my Math class. & + \\
\hline Core & I don't really care about doing well in Math. & - \\
\hline Core & When I have to do work in my Math class, I feel bored. & - \\
\hline Core & Math scares me. & - \\
\hline
\end{tabular}




\begin{tabular}{|c|c|c|}
\hline Online & In Math class, I read the curriculum carefully & + \\
\hline \multicolumn{3}{|l|}{ Resilience } \\
\hline Core & If a problem in Math is really difficult, I just work harder. & + \\
\hline Core & $\begin{array}{l}\text { If I don't do well on a Math test, I check my feedback and } \\
\text { figure out how to do better next time. }\end{array}$ & + \\
\hline Core & $\begin{array}{l}\text { If I don't understand something in Math, I ask the teacher for } \\
\text { help. }\end{array}$ & + \\
\hline Core & $\begin{array}{l}\text { If something bad happens in Math class, I don't let it get me } \\
\text { down. }\end{array}$ & + \\
\hline Core & When an assignment in Math is hard, I put it off or skip it. & - \\
\hline Core & $\begin{array}{l}\text { When I run into a hard question or problem in Math class, I } \\
\text { get all confused. }\end{array}$ & - \\
\hline Drill - used & $\begin{array}{l}\text { When I have difficulty learning something, I remind myself } \\
\text { that this is important in reaching my own personal goals. }\end{array}$ & + \\
\hline Drill - used & $\begin{array}{l}\text { When I don't do well on a test in Math, I tell myself it didn't } \\
\text { matter. }\end{array}$ & - \\
\hline Drill - used & If a problem in Math is really hard, l'll probably get it wrong. & - \\
\hline
\end{tabular}

Table A-2. Science:

\begin{tabular}{|r|l|l|}
\hline IDENTITY & & \\
\hline Core & I am the kind of person who can succeed in Science. & + \\
\hline Core & I want to be in a Science-related field when I grow up. & + \\
\hline Core & People like me do not get jobs in Science. & - \\
\hline Core & Science doesn't have anything to do with me. & - \\
\hline Relatedness & & \\
\hline Core & Science is a good place for students like me. & + \\
\hline Core & Sometimes I feel like I don't belong in Science. & - \\
\hline Competence & & \\
\hline
\end{tabular}




\begin{tabular}{|r|l|l|}
\hline Core & I am good at Science. & + \\
\hline Core & I don't have the brains to do well in Science. & - \\
\hline Drill - used & If I decide to learn something hard in Science, I can do it. & + \\
\hline Autonomy & Why do I do my work in Science/Math? & \\
\hline Core & $\begin{array}{r}\text { I do my work in Science because it is personally important to } \\
\text { me. }\end{array}$ & + \\
\hline Core & I do my work in Science because I have to. & - \\
\hline Drill - used & I do my work in Science because it is interesting. & + \\
\hline Drill - used & I do my work in Science because I want to do well for my & \\
\hline teacher. & & \\
\hline Purpose & I believe that Science can help make the world a better & + \\
\hline place. & Science is important for my future career. & + \\
\hline Core & I don't see the point of anything we are learning in Science. & - \\
\hline Core & There's no reason to learn Science. & - \\
\hline
\end{tabular}

\begin{tabular}{|r|l|l|}
\hline Engagement & & \\
\hline Core & I try hard to do well in Science. & + \\
\hline Core & $\begin{array}{l}\text { When we work on something in Science, it's pretty } \\
\text { interesting. }\end{array}$ & + \\
\hline Core & I look forward to doing my Science work. & + \\
\hline Core & I don't really care about doing well in Science. & - \\
\hline Core & Science scares me. & - \\
\hline Resilience & & \\
\hline Core & If a problem in Science is really difficult, I just work harder. & + \\
\hline
\end{tabular}




\begin{tabular}{|r|l|l|}
\hline Core & $\begin{array}{l}\text { If I don't do well on a Science test, I check my feedback and } \\
\text { figure out how to do better next time. }\end{array}$ & + \\
\hline Core & $\begin{array}{l}\text { If I don't understand something in Science, I ask the teacher } \\
\text { for help. }\end{array}$ & + \\
\hline Core & $\begin{array}{l}\text { If something bad happens in Science class, I don't let it get } \\
\text { me down. }\end{array}$ & + \\
\hline Core & $\begin{array}{l}\text { When an assignment in Science is hard, I just put it off or } \\
\text { skip it. }\end{array}$ & - \\
\hline Core & $\begin{array}{l}\text { When I run into a hard question or problem in Science class, } \\
\text { I get all confused. }\end{array}$ & - \\
\hline Core & $\begin{array}{l}\text { When I don't understand something in Science, I feel like it's } \\
\text { all my fault. }\end{array}$ & - \\
\hline Drill - used & $\begin{array}{l}\text { When I don't do well on a test in Science, I tell myself it } \\
\text { didn't matter. }\end{array}$ & - \\
\hline Drill - used & $\begin{array}{l}\text { If a problem in Science is really hard, I'll probably get it } \\
\text { wrong. }\end{array}$ & - \\
\hline
\end{tabular}

Table A-3. Technology:

\begin{tabular}{|r|l|l|}
\hline Resilience & & \\
\hline Core & $\begin{array}{l}\text { If I have a problem with technology, I just work harder and I'll } \\
\text { figure it out. }\end{array}$ & + \\
\hline Core & If I have a technological issue, I ask a teacher for help. & + \\
\hline Core & $\begin{array}{l}\text { If a piece of technology JUST ISN'T WORKING, I don't let it } \\
\text { get me down. }\end{array}$ & + \\
\hline Core & $\begin{array}{l}\text { When I don't understand something technological, I feel like it's } \\
\text { all my fault. }\end{array}$ & - \\
\hline Drill - used & $\begin{array}{l}\text { When I have trouble with technology, I usually figure it out in } \\
\text { the end. }\end{array}$ & + \\
\hline Drill - used & $\begin{array}{l}\text { If a technological problem is really hard, I probably couldn't } \\
\text { solve it. }\end{array}$ & - \\
\hline
\end{tabular}




\begin{tabular}{|r|l|l|}
\hline IDENTITY & & \\
\hline Core & $\begin{array}{l}\text { I am the kind of person who can succeed in a technological } \\
\text { field. }\end{array}$ & + \\
\hline Core & I want to be involved with technology when I grow up. & + \\
\hline Core & People like me do not get jobs in the technology sector. & - \\
\hline Core & Technology doesn't have anything to do with me. & - \\
\hline Competence & & \\
\hline Core & I am good at technology. & + \\
\hline Core & I don't have the brains to understand technology. & - \\
\hline Drill - used & I can figure out technology if I want to. & + \\
\hline Drill - & If I decide to learn technology that's difficult, I can do it. & + \\
\hline used & & - \\
\hline Drill - used & I am not very good at technology. & \\
\hline Purpose & & + \\
\hline Core & Technology is important for my future career. & - \\
\hline Core & I don't see the point of learning technology. & \\
\hline
\end{tabular}




\section{A-3: Student Survey of Motivational Practices and Teacher-Student Relationship}

I wrote the first half of this survey using the practices from my Teacher Survey and anything else I could think of that could make a difference, some of it based on my research. The survey asked this entire table twice, once for the student's math teacher and the other for their science teacher, preceded by the question "Who is your Math/Science Teacher?"

Prompt: Please fill in the table below based on how motivating you find it when your Math/Science teacher does the following:

\begin{tabular}{|c|c|c|c|c|}
\hline \multicolumn{5}{|c|}{ ANSWER RESPONSE SCALE } \\
\hline $\begin{array}{c}\text { My teacher } \\
\text { doesn't do this }\end{array}$ & $\begin{array}{c}\text { This } \\
\text { discourages me }\end{array}$ & $\begin{array}{c}\text { This is not } \\
\text { motivational }\end{array}$ & $\begin{array}{c}\text { I'm motivated } \\
\text { by this }\end{array}$ & $\begin{array}{c}\text { This really } \\
\text { motivates me }\end{array}$ \\
1 & 2 & 3 & 4 & 5 \\
\hline
\end{tabular}

Table A-4. Motivating Factors

\begin{tabular}{|l|l|}
\hline $\begin{array}{l}\text { Individual } \\
\text { Contact }\end{array}$ & How motivating do you find it when your teacher... \\
\hline & Texts you? \\
\hline & Calls you? \\
\hline & Emails you directly? \\
\hline & Contacts you because you haven't been working? \\
\hline & Schedules a meeting with you in person? \\
\hline Parent Contact & How motivating do you find it when your teacher... \\
\hline & Texts or calls your parents? \\
\hline Peacher & How motivating do you find it when your teacher... \\
\hline & Posts announcements in Brainhoney? \\
\hline & Makes videos of him/herself? \\
\hline & Updates a blog? \\
\hline
\end{tabular}




\begin{tabular}{|r|l|}
\hline $\begin{array}{r}\text { Improving } \\
\text { Class } \\
\text { Experience }\end{array}$ & How motivating do you find it when your teacher... \\
\hline & Writes his/her own curriculum? \\
\hline & Runs a specific lab in the building? \\
\hline & Makes videos of your class? \\
\hline Teacher & Conducts a virtual lecture at a set time? \\
\hline & Makes a template for an assignment? \\
\hline & Quickly answers your emails? \\
\hline & Is available during physical lab times? \\
\hline & Is available during virtual lab times? \\
\hline & Grades within a day? \\
\hline & Grades within two days? \\
\hline Other questions & How motivating do you find it when your teacher... \\
\hline & Automatically allows retries on low-grade assignments? \\
\hline & Asks you about your personal life? \\
\hline & Uses encouraging language when grading assignments? \\
\hline
\end{tabular}

The second half of the survey came from the common measures paper (Saxton et al., 2014). Again this table was duplicated so there was one for the student's math teacher and another for the student's science teacher.

Just like the Affective Variable survey, the $+/$ - designation is used in data analysis: negative questions get their scores inverted so the section can be properly averaged. 


\begin{tabular}{|c|c|c|c|c|}
\hline \multicolumn{5}{|l|}{ ANSWER RESPONSE SCALE } \\
\hline I don't know / can't tell & Not at all true & A little bit true & Fairly true & Totally true \\
1 & 2 & 3 & 4 & 5 \\
\hline
\end{tabular}

\section{Table A-5. Relationship Survey:}

\begin{tabular}{|c|c|c|}
\hline Involvement & My Science/Math teacher... & \\
\hline Teacher & likes me. & + \\
\hline Teacher & appreciates and respects me. & + \\
\hline Teacher & doesn't understand me. & - \\
\hline Teacher & doesn't even know who I am. & - \\
\hline Teacher & really cares about me. & + \\
\hline Teacher & is never there for me. & - \\
\hline Structure & My Science/Math teacher... & \\
\hline Teacher & believes I can do good work. & + \\
\hline Teacher & explains Science/Math in ways that I can understand. & + \\
\hline Teacher & is inconsistent with expectations & - \\
\hline Teacher & isn't available for help when I need it. & - \\
\hline Teacher & shows me how to solve problems for myself. & + \\
\hline Teacher & doesn't make it clear what he/she expects of me in class. & - \\
\hline Autonomy Support & My Science/Math teacher... & \\
\hline Core & listens to my ideas. & + \\
\hline Core & explains why Science/Math is important. & + \\
\hline Core & is always getting on my case about schoolwork. & - \\
\hline Drill & $\begin{array}{l}\text { When it comes to assignments in Science/Math, my teacher gives me all } \\
\text { kinds of things to choose from. }\end{array}$ & + \\
\hline \multirow[t]{2}{*}{ Teacher Engagement } & My Science/Math teacher... & \\
\hline & loves teaching me about Science/Math. & + \\
\hline
\end{tabular}




\begin{tabular}{|r|l|c|}
\hline & thinks that Science/Math is interesting and important. & + \\
\hline $\begin{array}{l}\text { Authentic Academic } \\
\text { Work }\end{array}$ & & \\
\hline Core & We are learning important things in Science/Math. & + \\
\hline Core & Our projects in Science/Math are interesting and fun. & + \\
\hline Core & All the work we do in Science/Math class is worth the effort. & \\
\hline Core & $\begin{array}{l}\text { The stuff we learn in Science/Math class is connected to the real world of } \\
\text { Science/Math. }\end{array}$ & + \\
\hline Communications & My Science/Math Teacher's... & + \\
\hline & Feedback is instructive and helpful & + \\
\hline & $\begin{array}{l}\text { Communications are friendly, so I know I can ask him/her questions any } \\
\text { time }\end{array}$ & - \\
\hline & Grading is too slow & - \\
\hline & Response time to questions is too slow & - \\
\hline & Communications seem bossy and condescending (too 'teacher-y') & \\
\hline &
\end{tabular}


Appendix B: Data

B-1: Teacher Survey of Practices, Survey in Appendix A-1

\begin{tabular}{|c|c|c|c|c|c|}
\hline Scale: & $\begin{array}{c}\text { That's not } \\
\text { my style }\end{array}$ & $\begin{array}{c}\text { Once } \\
\text { every } \\
\text { couple of } \\
\text { months }\end{array}$ & $\begin{array}{c}\text { Once a } \\
\text { month }\end{array}$ & $\begin{array}{c}2-3 \text { times } \\
\text { a month }\end{array}$ & Weekly \\
\hline & 1 & 2 & 3 & 4 & 5 \\
\hline
\end{tabular}

Table A-6. Top 5 High School Teachers:

\begin{tabular}{|c|c|c|c|c|c|}
\hline Practice & Martin & Howell & Reed & Cook & Everett \\
\hline Text with students & 4 & 5 & 4 & 3 & 4 \\
\hline Call students & 3 & 5 & 3 & 3 & 5 \\
\hline $\begin{array}{l}\text { Go through classes and } \\
\text { contact disengaged students }\end{array}$ & 4 & 3 & 2 & 3 & 3 \\
\hline $\begin{array}{l}\text { Talk with students } \\
\text { individually for Discussion- } \\
\text { based Assessments }\end{array}$ & 5 & 2 & 3 & 3 & 5 \\
\hline Check in with mentees & 3 & 5 & 4 & 5 & 3 \\
\hline Text Parents & 2 & 5 & 3 & 3 & 4 \\
\hline Call Parents & 2 & 4 & 3 & 3 & 4 \\
\hline Email Parents & 5 & 5 & 3 & 5 & 5 \\
\hline Conduct virtual office hours & 5 & 5 & 5 & 1 & 5 \\
\hline Make videos of yourself & 1 & 5 & 2 & 3 & 2 \\
\hline $\begin{array}{c}\text { Post announcements in } \\
\text { Brainhoney }\end{array}$ & 1 & 1 & 3 & 2 & 1 \\
\hline Update a blog for students & 1 & 5 & 2 & 3 & 2 \\
\hline $\begin{array}{l}\text { Run a lab with a specific } \\
\text { plan, rather than open lab or } \\
\text { office hours }\end{array}$ & 2 & 1 & 3 & 4 & 2 \\
\hline $\begin{array}{l}\text { Conduct virtual organized } \\
\text { lectures or classes }\end{array}$ & 2 & 1 & 5 & 3 & 5 \\
\hline
\end{tabular}




\begin{tabular}{|c|c|c|c|c|c|}
\hline Write new curriculum & 2 & 1 & 3 & 5 & 2 \\
\hline Make videos of your class & 1 & 3 & 2 & 3 & 3 \\
\hline $\begin{array}{c}\text { Grade work soon after its } \\
\text { turned in }\end{array}$ & 1 & 5 & 1 & 5 & 2 \\
\hline $\begin{array}{l}\text { Respond quickly to student } \\
\text { emails }\end{array}$ & 3 & 5 & 3 & 3 & 3 \\
\hline $\begin{array}{l}\text { High School average } \\
\text { percent of students more } \\
\text { than } 20 \% \text { behind pace: }\end{array}$ & $38.13 \%$ & $39.72 \%$ & $42.14 \%$ & $45.39 \%$ & $52.10 \%$ \\
\hline $\begin{array}{l}\text { Middle School average } \\
\text { percent of students more } \\
\text { than } 20 \% \text { behind pace: }\end{array}$ & $36.34 \%$ & & $36.78 \%$ & & \\
\hline
\end{tabular}

Table A-7. Bottom 4 High School Teachers:

\begin{tabular}{|c|c|c|c|c|}
\hline Practice & Corona & Diphily & Goudy & Barrentine \\
\hline Text with students & 5 & 4 & 5 & 5 \\
\hline Call students & 5 & 4 & 5 & 3 \\
\hline $\begin{array}{c}\text { Go through classes } \\
\text { and contact } \\
\text { disengaged students }\end{array}$ & 3 & 3 & 4 & 2 \\
\hline $\begin{array}{c}\text { Talk with students } \\
\text { individually for } \\
\text { Discussion-based } \\
\text { Assessments }\end{array}$ & 5 & 5 & 5 & 5 \\
\hline $\begin{array}{c}\text { Check in with mentees } \\
\text { Text Parents }\end{array}$ & 4 & 5 & 5 & 4 \\
\hline Call Parents & 5 & 4 & 5 & 2 \\
\hline Email Parents & 5 & 5 & 5 & 2 \\
\hline $\begin{array}{c}\text { Conduct virtual office } \\
\text { hours }\end{array}$ & 5 & 5 & 5 & 5 \\
\hline $\begin{array}{c}\text { Make videos of } \\
\text { yourself }\end{array}$ & 3 & 4 & 1 & 2 \\
\hline $\begin{array}{c}\text { Post announcements } \\
\text { in Brainhoney }\end{array}$ & 3 & 5 & 4 & 3 \\
\hline
\end{tabular}




\begin{tabular}{|c|c|c|c|c|}
\hline $\begin{array}{l}\text { Update a blog for } \\
\text { students }\end{array}$ & 1 & 1 & 1 & 5 \\
\hline $\begin{array}{c}\text { Run a lab with a } \\
\text { specific plan, rather } \\
\text { than open lab or office } \\
\text { hours }\end{array}$ & 4 & 2 & 4 & 5 \\
\hline $\begin{array}{c}\text { Conduct virtual } \\
\text { organized lectures or } \\
\text { classes }\end{array}$ & 4 & 4 & 1 & 1 \\
\hline Write new curriculum & 5 & 2 & 3 & 3 \\
\hline $\begin{array}{l}\text { Make videos of your } \\
\text { class }\end{array}$ & 3 & 1 & 1 & 4 \\
\hline $\begin{array}{l}\text { Grade work soon after } \\
\text { its turned in }\end{array}$ & 2 & 1 & 5 & 3 \\
\hline $\begin{array}{l}\text { Respond quickly to } \\
\text { student emails }\end{array}$ & 4 & 4 & 3 & 5 \\
\hline $\begin{array}{l}\text { High School average } \\
\text { percent of students } \\
\text { more than } 20 \% \text { behind } \\
\text { pace: }\end{array}$ & $60.26 \%$ & $61.50 \%$ & $62.65 \%$ & $64.76 \%$ \\
\hline $\begin{array}{l}\text { Middle School average } \\
\text { percent of students } \\
\text { more than } 20 \% \text { behind } \\
\text { pace: }\end{array}$ & & $30.13 \%$ & $34.70 \%$ & $32.21 \%$ \\
\hline
\end{tabular}

\section{B-2: Teacher-side analysis of Assignments-Behind Data}

Table A-8. Overall Data:

\begin{tabular}{|c|c|c|c|c|c|c|c|}
\hline Teacher & $\begin{array}{l}\text { Average } \\
\text { A.B. }\end{array}$ & $\begin{array}{l}\text { Average } \\
\text { A.B. } \%\end{array}$ & $\begin{array}{l}\text { Average } \\
\text { Student } \\
\text { s per } \\
\text { class }\end{array}$ & $\begin{array}{l}\text { Average } \\
\text { number } \\
\text { of } \\
\text { Student } \\
\text { s }>20 \% \\
\text { A.B. per } \\
\text { class }\end{array}$ & $\begin{array}{l}\text { Percent } \\
\text { of } \\
\text { students } \\
>20 \% \\
\text { A.B. }\end{array}$ & $\begin{array}{l}\text { High } \\
\text { School } \\
\text { more } \\
\text { than } \\
20 \% \\
\text { behind }\end{array}$ & $\begin{array}{l}\text { Middle } \\
\text { School } \\
\text { more } \\
\text { than } \\
20 \% \\
\text { behind }\end{array}$ \\
\hline Martin & 7.95 & $20.03 \%$ & 29.5 & 10.79 & $34.71 \%$ & $38.13 \%$ & $36.34 \%$ \\
\hline Howell & 7.24 & $22.50 \%$ & 90.29 & 37.14 & $39.31 \%$ & $39.72 \%$ & \\
\hline Reed & 11.27 & $21.72 \%$ & 57.54 & 24.69 & $38.42 \%$ & $42.14 \%$ & $36.78 \%$ \\
\hline Cook & 10.5 & $24.47 \%$ & 43.4 & 19 & $36.89 \%$ & $45.39 \%$ & \\
\hline Everett & 13.33 & $30.03 \%$ & 39.38 & 20.85 & $52.92 \%$ & $52.10 \%$ & \\
\hline Corona & 16.4 & $34.09 \%$ & 69.86 & 43.29 & $60.21 \%$ & $60.26 \%$ & \\
\hline Diphily & 20.23 & $30.69 \%$ & 40.08 & 22.85 & $53.83 \%$ & $61.50 \%$ & $30.13 \%$ \\
\hline Goudy & 12.42 & $26.69 \%$ & 59 & 27.22 & $50.60 \%$ & $62.65 \%$ & $34.70 \%$ \\
\hline
\end{tabular}


\begin{tabular}{|l|l|l|l|l|l|l|l|} 
Barrentine & 11.44 & $28.86 \%$ & 38.36 & 18.36 & $47.01 \%$ & $64.76 \%$ & $32.21 \%$ \\
\hline
\end{tabular}

Table A-9. High School Subject Breakdown

\begin{tabular}{|c|c|c|c|c|c|}
\hline Teacher/Subject & $\begin{array}{l}\text { Number of } \\
\text { Students }\end{array}$ & $\begin{array}{l}\text { Average } \\
\text { A.B. } \%\end{array}$ & $\begin{array}{l}\text { Average } \\
\text { Students } \\
\text { per class }\end{array}$ & $\begin{array}{l}\text { Average } \\
\text { number of } \\
\text { Students } \\
>20 \% \text { A.B. } \\
\text { per class }\end{array}$ & $\begin{array}{l}\text { Percent of } \\
\text { students }>20 \% \\
\text { A.B. }\end{array}$ \\
\hline $\begin{array}{l}\text { Barrentine } \\
\text { Science }\end{array}$ & 214 & $39.02 \%$ & 43 & 27 & $64.76 \%$ \\
\hline Cook English & 370 & $24.47 \%$ & 49 & 23.5 & $45.39 \%$ \\
\hline Corona English & 422 & $33.72 \%$ & 70.33 & 44.33 & $61.05 \%$ \\
\hline $\begin{array}{l}\text { Corona Social } \\
\text { Studies }\end{array}$ & 66 & $30.77 \%$ & 67 & 37 & $55.22 \%$ \\
\hline Diphily Math & 424 & $35.32 \%$ & 42.4 & 27.1 & $61.50 \%$ \\
\hline Everett Math & 25 & $35.09 \%$ & 25 & 20 & $80.00 \%$ \\
\hline Everett Science & 486 & $29.61 \%$ & 40.58 & 20.92 & $50.66 \%$ \\
\hline Goudy Math & 24 & $33.45 \%$ & 17.6 & 10.8 & $59.52 \%$ \\
\hline $\begin{array}{l}\text { Goudy Physical } \\
\text { Education }\end{array}$ & 174 & $37.63 \%$ & 57.33 & 29.67 & $63.08 \%$ \\
\hline $\begin{array}{l}\text { Howell Social } \\
\text { Studies }\end{array}$ & 543 & $23.70 \%$ & 108.8 & 47.4 & $41.97 \%$ \\
\hline $\begin{array}{l}\text { Howell } \\
\text { Psychology }\end{array}$ & 76 & $14.63 \%$ & 76 & 18 & $23.68 \%$ \\
\hline Martin - art & 138 & $20.69 \%$ & 34.5 & 14 & $38.13 \%$ \\
\hline $\begin{array}{l}\text { Reed - Health and } \\
\text { Food Safety }\end{array}$ & 450 & $24.35 \%$ & 113 & 51.75 & $42.14 \%$ \\
\hline
\end{tabular}

Table A-10. Middle School Subject Breakdown

\begin{tabular}{|c|c|c|c|c|c|}
\hline $\begin{array}{l}\text { Teachers and } \\
\text { Subject }\end{array}$ & $\begin{array}{l}\text { Number of } \\
\text { Students }\end{array}$ & $\begin{array}{l}\text { Average } \\
\text { A.B. } \%\end{array}$ & $\begin{array}{l}\text { Average } \\
\text { Students } \\
\text { per class }\end{array}$ & $\begin{array}{l}\text { Average } \\
\text { number of } \\
\text { Students } \\
>20 \% \text { A.B. } \\
\text { per class }\end{array}$ & $\begin{array}{l}\text { All Students } \\
\text { Percent }>20 \% \\
\text { A.B. }\end{array}$ \\
\hline $\begin{array}{l}\text { Barrentine } \\
\text { Science }\end{array}$ & 206 & $20.40 \%$ & 34.5 & 11.17 & $32.21 \%$ \\
\hline Diphily Math & 43 & $15.13 \%$ & 22 & 6.5 & $30.13 \%$ \\
\hline $\begin{array}{l}\text { Goudy } \\
\text { Keyboarding }\end{array}$ & 81 & $21.23 \%$ & 82 & 30 & $36.59 \%$ \\
\hline Goudy Math & 103 & $18.76 \%$ & 74 & 26 & $33.21 \%$ \\
\hline Martin Art & 33 & $16.50 \%$ & 18.6 & 4.64 & $23.67 \%$ \\
\hline Martin Math & 41 & $21.78 \%$ & 21 & 7 & $34.72 \%$ \\
\hline $\begin{array}{l}\text { Martin Social } \\
\text { Studies }\end{array}$ & 198 & $20.69 \%$ & 33.17 & 12.17 & $36.67 \%$ \\
\hline Reed Health & 98 & $19.40 \%$ & 33 & 12 & $34.12 \%$ \\
\hline $\begin{array}{l}\text { Reed Language } \\
\text { arts }\end{array}$ & 198 & $21.11 \%$ & 32.83 & 13 & $38.10 \%$ \\
\hline
\end{tabular}




\section{Appendix B-3: Student Affective Variable and Assignments Behind}

Table A-11. Middle School Affective Variable Survey

\begin{tabular}{|c|c|c|c|c|c|}
\hline Scale: & Not at all true & $\begin{array}{c}\text { A little bit } \\
\text { true }\end{array}$ & Somewhat true & Fairly true & Totally true \\
\hline & 1 & 2 & 3 & 4 & 5 \\
\hline
\end{tabular}

Colored Text represents a negative statement; the score was inverted for those:

\begin{tabular}{|c|c|c|c|c|c|c|c|c|}
\hline Statement: & Zz01 & $\mathrm{Zz02}$ & Zz06 & Zz10 & Zz15 & Zz19 & Zz20 & Zz21 \\
\hline $\begin{array}{l}\text { I am the kind of person who } \\
\text { can succeed in Math. }\end{array}$ & 3 & 2 & 1 & 5 & 2 & 3 & 5 & 5 \\
\hline $\begin{array}{l}\text { I want to be in a Math- } \\
\text { related career when I grow } \\
\text { up. }\end{array}$ & 1 & 2 & 2 & 3 & 3 & 1 & 1 & 2 \\
\hline $\begin{array}{l}\text { People like me do not get } \\
\text { jobs in Math. }\end{array}$ & 1 & 3 & 5 & 5 & 5 & 4 & 5 & 3 \\
\hline $\begin{array}{l}\text { Math doesn't have anything } \\
\text { to do with my life. }\end{array}$ & 1 & 4 & 3 & 5 & 5 & 4 & 5 & 3 \\
\hline Identity Average & 1.5 & 2.75 & 2.75 & 4.5 & 3.75 & 3 & 4 & 3.25 \\
\hline $\begin{array}{l}\text { Math class is a good place } \\
\text { for students like me. }\end{array}$ & 2 & 2 & 4 & 3 & 3 & 3 & 2 & 4 \\
\hline $\begin{array}{l}\text { Sometimes I feel like I don't } \\
\text { belong in Math. }\end{array}$ & 1 & 2 & 1 & 4 & 4 & 2 & 5 & 5 \\
\hline Relatedness Average & 1.5 & 2 & 2.5 & 3.5 & 3.5 & 2.5 & 3.5 & 4.5 \\
\hline I am good at Math. & 2 & 3 & 1 & 4 & 3 & 3 & 5 & 5 \\
\hline $\begin{array}{l}\text { I don't have the brains to do } \\
\text { well in Math. }\end{array}$ & 2 & 4 & 4 & 5 & 5 & 3 & 5 & 5 \\
\hline Competence Average & 2 & 3.5 & 2.5 & 4.5 & 4 & 3 & 5 & 5 \\
\hline $\begin{array}{l}\text { I do my work in Math } \\
\text { because it is personally } \\
\text { important to me. }\end{array}$ & 2 & 2 & 4 & 5 & 4 & 2 & 5 & 2 \\
\hline $\begin{array}{l}\text { I do my work in Math } \\
\text { because they make us do it. }\end{array}$ & 1 & 2 & 5 & 5 & 5 & 5 & 5 & 3 \\
\hline $\begin{array}{l}\text { I do my work in Math } \\
\text { because I want to do well for } \\
\text { my teacher }\end{array}$ & 1 & 2 & 2 & 1 & 3 & 3 & 2 & 2 \\
\hline Autonomy Average & 1.33 & 2.00 & 3.67 & 3.67 & 4.00 & 3.33 & 4.00 & 2.33 \\
\hline
\end{tabular}




\begin{tabular}{|c|c|c|c|c|c|c|c|c|}
\hline $\begin{array}{l}\text { I believe that Math can help } \\
\text { make the world a better } \\
\text { place. }\end{array}$ & 5 & 3 & 5 & 5 & 3 & 3 & 3 & 2 \\
\hline $\begin{array}{l}\text { Math is important for my } \\
\text { future career. }\end{array}$ & 2 & 4 & 4 & 5 & 3 & 3 & 5 & 3 \\
\hline $\begin{array}{l}\text { I don't see the point of } \\
\text { anything we are learning in } \\
\text { Math. }\end{array}$ & 2 & 3 & 5 & 4 & 5 & 2 & 5 & 4 \\
\hline $\begin{array}{l}\text { There's no reason to learn } \\
\text { Math. }\end{array}$ & 4 & 2 & 5 & 5 & 5 & 3 & 5 & 5 \\
\hline Purpose Average & 3.25 & 3 & 4.75 & 4.75 & 4 & 2.75 & 4.5 & 3.5 \\
\hline I try hard to do well in Math. & 4 & 4 & 3 & 5 & 4 & 5 & 5 & 5 \\
\hline $\begin{array}{l}\text { When we work on something } \\
\text { in Math, it's pretty } \\
\text { interesting. }\end{array}$ & 1 & 3 & 4 & 4 & 3 & 3 & 3 & 2 \\
\hline $\begin{array}{l}\text { I look forward to working on } \\
\text { my Math class. }\end{array}$ & 1 & 3 & 3 & 4 & 2 & 2 & 4 & 4 \\
\hline $\begin{array}{l}\text { I don't really care about } \\
\text { doing well in Math. }\end{array}$ & 2 & 4 & 5 & 5 & 5 & 5 & 5 & 5 \\
\hline $\begin{array}{l}\text { When I have to do work in } \\
\text { my Math class, I feel bored. }\end{array}$ & 1 & 3 & 5 & 5 & 4 & 3 & 4 & 4 \\
\hline Math scares me. & 1 & 2 & 3 & 5 & 5 & 5 & 5 & 5 \\
\hline $\begin{array}{l}\text { In Math class, I read the } \\
\text { curriculum carefully }\end{array}$ & 3 & 5 & 4 & 5 & 3 & 4 & 4 & 4 \\
\hline Engagement Average & 1.86 & 3.43 & 3.86 & 4.71 & 3.71 & 3.86 & 4.29 & 4.14 \\
\hline $\begin{array}{l}\text { If a problem in Math is really } \\
\text { difficult, I just work harder. }\end{array}$ & 2 & 3 & 3 & 5 & 2 & 5 & 5 & 3 \\
\hline $\begin{array}{l}\text { If I don't do well on a Math } \\
\text { test, I check my feedback } \\
\text { and figure out how to do } \\
\text { better next time. }\end{array}$ & 3 & 4 & 3 & 5 & 3 & 5 & 5 & 4 \\
\hline $\begin{array}{l}\text { If I don't understand } \\
\text { something in Math, I ask the } \\
\text { teacher for help. }\end{array}$ & 2 & 4 & 1 & 4 & 5 & 3 & 5 & 3 \\
\hline
\end{tabular}




\begin{tabular}{|c|c|c|c|c|c|c|c|c|}
\hline $\begin{array}{l}\text { If something bad happens in } \\
\text { Math class, I don't let it get } \\
\text { me down. }\end{array}$ & 2 & 3 & 3 & 5 & 1 & 2 & 4 & 3 \\
\hline $\begin{array}{l}\text { When an assignment in Math } \\
\text { is hard, I put it off or skip it. }\end{array}$ & 1 & 4 & 3 & 4 & 3 & 4 & 4 & 5 \\
\hline $\begin{array}{l}\text { When I run into a hard } \\
\text { question or problem in Math } \\
\text { class, I get all confused. }\end{array}$ & 1 & 3 & 3 & 2 & 2 & 2 & 3 & 3 \\
\hline $\begin{array}{l}\text { When I have difficulty } \\
\text { learning something, I remind } \\
\text { myself that this is important } \\
\text { in reaching my own personal } \\
\text { goals. }\end{array}$ & 2 & 3 & 4 & 5 & 3 & 2 & 5 & 4 \\
\hline $\begin{array}{l}\text { When I don't do well on a } \\
\text { test in Math, I tell myself it } \\
\text { didn't matter. }\end{array}$ & 2 & 4 & 4 & 4 & 4 & 4 & 5 & 5 \\
\hline $\begin{array}{l}\text { If a problem in Math is really } \\
\text { hard, I'll probably get it } \\
\text { wrong. }\end{array}$ & 1 & 3 & 2 & 5 & 5 & 3 & 5 & 4 \\
\hline Resilience Average & 1.78 & 3.44 & 2.89 & 4.33 & 3.11 & 3.33 & 4.56 & 3.78 \\
\hline Math Overall Average & 1.95 & 3.06 & 3.41 & 4.35 & 3.62 & 3.26 & 4.35 & 3.81 \\
\hline Average A.B. in Math & 1.25 & -0.25 & 27.00 & 1.25 & 11.00 & 20.25 & 28.75 & 1.75 \\
\hline $\begin{array}{l}\text { I am the kind of person who } \\
\text { can succeed in Science. }\end{array}$ & 5 & & 4 & 4 & 3 & 4 & 4 & 5 \\
\hline $\begin{array}{l}\text { I want to be in a Science- } \\
\text { related field when I grow up. }\end{array}$ & 5 & & 5 & 1 & 4 & 2 & 4 & 3 \\
\hline $\begin{array}{l}\text { People like me do not get } \\
\text { jobs in Science. }\end{array}$ & 5 & & 5 & 5 & 5 & 4 & 5 & 4 \\
\hline $\begin{array}{l}\text { Science doesn't have } \\
\text { anything to do with me. }\end{array}$ & 5 & & 5 & 4 & 5 & 3 & 5 & 5 \\
\hline Identity Average & 5 & & 4.75 & 3.5 & 4.25 & 3.25 & 4.5 & 4.25 \\
\hline $\begin{array}{l}\text { Science is a good place for } \\
\text { students like me. }\end{array}$ & 5 & & 5 & 2 & 4 & 2 & 4 & 5 \\
\hline
\end{tabular}




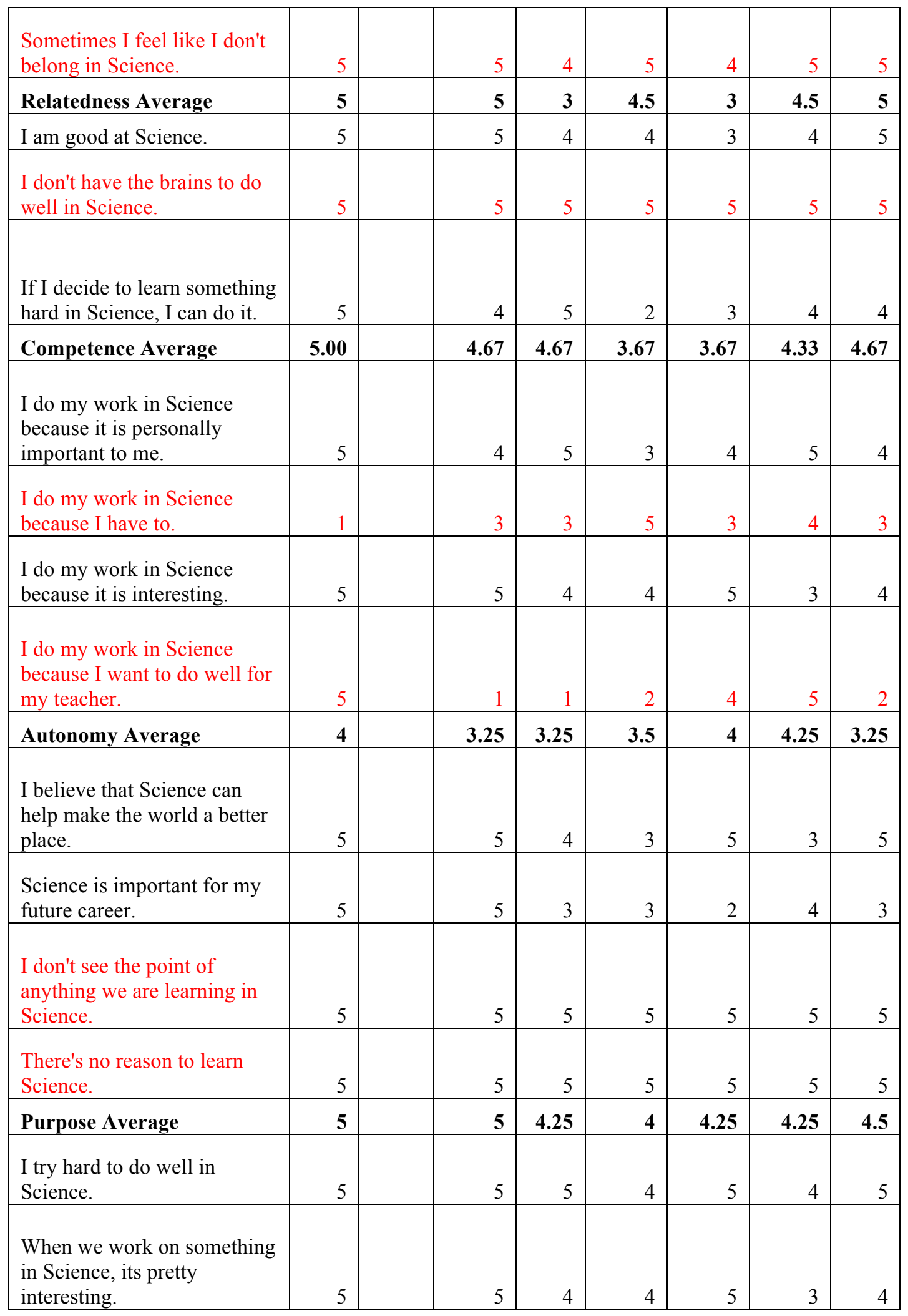




\begin{tabular}{|c|c|c|c|c|c|c|c|}
\hline $\begin{array}{l}\text { I look forward to doing my } \\
\text { Science work. }\end{array}$ & 5 & 1 & 4 & 3 & 4 & 4 & 5 \\
\hline $\begin{array}{l}\text { I don't really care about } \\
\text { doing well in Science. }\end{array}$ & 4 & 5 & 5 & 5 & 5 & 5 & 5 \\
\hline Science scares me. & 4 & 5 & 5 & 5 & 5 & 5 & 5 \\
\hline Engagement Average & 4.6 & 4.2 & 4.6 & 4.2 & 4.8 & 4.2 & 4.8 \\
\hline $\begin{array}{l}\text { If a problem in Science is } \\
\text { really difficult, I just work } \\
\text { harder. }\end{array}$ & 4 & 4 & 5 & 3 & 5 & 5 & 4 \\
\hline $\begin{array}{l}\text { If I don't do well on a } \\
\text { Science test, I check my } \\
\text { feedback and figure out how } \\
\text { to do better next time. }\end{array}$ & 4 & 5 & 5 & 3 & 5 & 5 & 4 \\
\hline $\begin{array}{l}\text { If I don't understand } \\
\text { something in Science, I ask } \\
\text { the teacher for help. }\end{array}$ & 3 & 2 & 4 & 5 & 3 & 5 & 4 \\
\hline $\begin{array}{l}\text { If something bad happens in } \\
\text { Science class, I don't let it get } \\
\text { me down. }\end{array}$ & 4 & 5 & 4 & 2 & 5 & 3 & 2 \\
\hline $\begin{array}{l}\text { When an assignment in } \\
\text { Science is hard, I just put it } \\
\text { off or skip it. }\end{array}$ & 3 & 2 & 4 & 4 & 2 & 5 & 5 \\
\hline $\begin{array}{l}\text { When I run into a hard } \\
\text { question or problem in } \\
\text { Science class, I get all } \\
\text { confused. }\end{array}$ & 4 & 1 & 4 & 2 & 3 & 3 & 4 \\
\hline $\begin{array}{l}\text { When I don't understand } \\
\text { something in Science, I feel } \\
\text { like it's all my fault. }\end{array}$ & 4 & 1 & 5 & 4 & 4 & 5 & 5 \\
\hline $\begin{array}{l}\text { When I don't do well on a } \\
\text { test in Science, I tell myself } \\
\text { it didn't matter. }\end{array}$ & 3 & 2 & 5 & 4 & 4 & 5 & 4 \\
\hline $\begin{array}{l}\text { If a problem in Science is } \\
\text { really hard, I'll probably get } \\
\text { it wrong. }\end{array}$ & 4 & 1 & 5 & 4 & 3 & 4 & 4 \\
\hline Resiliency Average & 3.67 & 2.56 & 4.56 & 3.44 & 3.78 & 4.44 & 4.00 \\
\hline Overall Science Average & 4.45 & 3.93 & 4.10 & 3.86 & 3.89 & 4.35 & 4.28 \\
\hline
\end{tabular}




\begin{tabular}{|c|c|c|c|c|c|c|c|c|}
\hline Average A.B. in Science & 1.00 & -0.50 & 9.50 & 1.00 & -0.50 & 12.00 & 20.50 & 0.00 \\
\hline $\begin{array}{l}\text { If I have a problem with } \\
\text { technology, I just work } \\
\text { harder and I'll figure it out. }\end{array}$ & 5 & 4 & 5 & 5 & 2 & 4 & 5 & 4 \\
\hline $\begin{array}{l}\text { If I have a technological } \\
\text { issue, I ask a teacher for } \\
\text { help. }\end{array}$ & 3 & 4 & 5 & 5 & 3 & 5 & 3 & 2 \\
\hline $\begin{array}{l}\text { If a piece of technology } \\
\text { JUST ISN'T WORKING, I } \\
\text { don't let it get me down. }\end{array}$ & 4 & 3 & 5 & 4 & 1 & 1 & 5 & 3 \\
\hline $\begin{array}{l}\text { When I don't understand } \\
\text { something technological, I } \\
\text { feel like it's all my fault. }\end{array}$ & 5 & 4 & 5 & 4 & 5 & 5 & 5 & 5 \\
\hline $\begin{array}{l}\text { When I have trouble with } \\
\text { technology, I usually figure it } \\
\text { out in the end. }\end{array}$ & 5 & 3 & 5 & 4 & 3 & 5 & 5 & 5 \\
\hline $\begin{array}{l}\text { If a technological problem is } \\
\text { really hard, I probably } \\
\text { couldn't solve it. }\end{array}$ & 4 & 4 & 2 & 4 & 4 & 2 & 5 & 4 \\
\hline Resilience Average & 4.33 & 3.67 & 4.50 & 4.33 & 3.00 & 3.67 & 4.67 & 3.83 \\
\hline $\begin{array}{l}\text { I am the kind of person who } \\
\text { can succeed in a } \\
\text { technological field. }\end{array}$ & 5 & 3 & 5 & 2 & 1 & 1 & 5 & 5 \\
\hline $\begin{array}{l}\text { I want to be involved with } \\
\text { technology when I grow up. }\end{array}$ & 5 & 4 & 5 & 2 & 2 & 1 & 2 & 5 \\
\hline $\begin{array}{l}\text { People like me do not get } \\
\text { jobs in the technology sector. }\end{array}$ & 4 & 4 & 5 & 5 & 5 & 5 & 5 & 5 \\
\hline $\begin{array}{l}\text { Technology doesn't have } \\
\text { anything to do with me. }\end{array}$ & 4 & 5 & 5 & 4 & 5 & 3 & 5 & 5 \\
\hline Identity Average & 4.5 & 4 & 5 & 3.25 & 3.25 & 2.5 & 4.25 & 5 \\
\hline I am good at technology. & 5 & 4 & 5 & 3 & 3 & 3 & 4 & 5 \\
\hline $\begin{array}{l}\text { I don't have the brains to } \\
\text { understand technology. }\end{array}$ & 5 & 4 & 5 & 5 & 5 & 4 & 5 & 5 \\
\hline $\begin{array}{l}\text { I can figure out technology if } \\
\text { I want to. }\end{array}$ & 5 & 4 & 5 & 5 & 2 & 4 & 5 & 5 \\
\hline
\end{tabular}




\begin{tabular}{|l|r|r|r|r|r|r|r|r|}
\hline $\begin{array}{l}\text { If I decide to learn } \\
\text { technology that's difficult, I } \\
\text { can do it. }\end{array}$ & 5 & 3 & 5 & 5 & 3 & 4 & 5 & 4 \\
\hline $\begin{array}{l}\text { I am not very good at } \\
\text { technology. }\end{array}$ & 5 & 4 & 5 & 4 & 5 & 2 & 5 & 5 \\
\hline Competence Average & $\mathbf{5}$ & $\mathbf{3 . 8}$ & $\mathbf{5}$ & $\mathbf{4 . 4}$ & $\mathbf{3 . 6}$ & $\mathbf{3 . 4}$ & $\mathbf{4 . 8}$ & $\mathbf{4 . 8}$ \\
\hline $\begin{array}{l}\text { Technology is important for } \\
\text { my future career. }\end{array}$ & 5 & 4 & 5 & & & & & \\
\hline $\begin{array}{l}\text { I don't see the point of } \\
\text { learning technology. }\end{array}$ & 5 & 5 & 5 & 5 & 5 & 2 & 2 & 5 \\
\hline Purpose Average & $\mathbf{5}$ & $\mathbf{4 . 5}$ & $\mathbf{5}$ & $\mathbf{3 . 5}$ & $\mathbf{3 . 5}$ & $\mathbf{3 . 5}$ & $\mathbf{3 . 5}$ & $\mathbf{5}$ \\
\hline Tech Average & 4.66 & 3.90 & 4.83 & 3.98 & 3.30 & 3.29 & 4.44 & 4.55 \\
\hline & & & & & & & & \\
Average A.B. in all classes & 1.55 & -0.55 & 15.10 & 0.64 & 3.21 & 12.90 & 21.20 & 1.25 \\
\hline
\end{tabular}

Table A-12. Top 8 High School Students by total average assignments behind

\begin{tabular}{|c|c|c|c|c|c|c|c|c|}
\hline Student: & Zz17 & Zz07 & Zz18 & $\mathrm{Zz} 11$ & $\mathrm{Zz05}$ & Zz22 & $\mathrm{Zz} 03$ & $\mathrm{Zz} 12$ \\
\hline $\begin{array}{l}\text { I am the kind of } \\
\text { person who can } \\
\text { succeed in Math. }\end{array}$ & 4 & 2 & 3 & 1 & 5 & 5 & 3 & 5 \\
\hline $\begin{array}{l}\text { I want to be in a } \\
\text { Math-related career } \\
\text { when I grow up. }\end{array}$ & 2 & 2 & 1 & 1 & 4 & 1 & 2 & 1 \\
\hline $\begin{array}{l}\text { People like me do not } \\
\text { get jobs in Math. }\end{array}$ & 3 & 4 & 2 & 1 & 2 & 3 & 5 & 3 \\
\hline $\begin{array}{l}\text { Math doesn't have } \\
\text { anything to do with } \\
\text { my life. }\end{array}$ & 5 & 3 & 3 & 1 & 5 & 4 & 5 & 5 \\
\hline Identity Average & 3.5 & 2.75 & 2.25 & 1 & 4 & 3.25 & 3.75 & 3.5 \\
\hline $\begin{array}{l}\text { Math class is a good } \\
\text { place for students like } \\
\text { me. }\end{array}$ & 5 & 2 & 2 & 1 & 5 & 3 & 5 & 3 \\
\hline $\begin{array}{l}\text { Sometimes I feel like I } \\
\text { don't belong in Math. }\end{array}$ & 5 & 2 & 3 & 1 & 5 & 5 & 5 & 3 \\
\hline Relatedness Average & 5 & 2 & 2.5 & 1 & 5 & 4 & 5 & 3 \\
\hline I am good at Math. & 4 & 3 & 3 & 1 & 4 & 4 & 4 & 4 \\
\hline $\begin{array}{l}\text { I don't have the brains } \\
\text { to do well in Math. }\end{array}$ & 5 & 3 & 4 & 1 & 5 & 5 & 5 & 5 \\
\hline Competence Average & 4.5 & 3 & 3.5 & 1 & 4.5 & 4.5 & 4.5 & 4.5 \\
\hline
\end{tabular}




\begin{tabular}{|c|c|c|c|c|c|c|c|c|}
\hline $\begin{array}{l}\text { I do my work in Math } \\
\text { because it is } \\
\text { personally important } \\
\text { to me. }\end{array}$ & 5 & 1 & 4 & 1 & 5 & 5 & 5 & 1 \\
\hline $\begin{array}{l}\text { I do my work in Math } \\
\text { because they make us } \\
\text { do it. }\end{array}$ & 5 & 4 & 3 & 1 & 5 & 1 & 3 & 2 \\
\hline $\begin{array}{l}\text { I do my work in Math } \\
\text { because I want to do } \\
\text { well for my teacher }\end{array}$ & 1 & 3 & 3 & 1 & 1 & 1 & 3 & 1 \\
\hline Autonomy Average & 3.67 & 2.67 & 3.33 & 1.00 & 3.67 & 2.33 & 3.67 & 1.33 \\
\hline $\begin{array}{l}\text { I believe that Math } \\
\text { can help make the } \\
\text { world a better place. }\end{array}$ & 4 & 2 & 3 & 1 & 5 & 2 & 4 & 2 \\
\hline $\begin{array}{l}\text { Math is important for } \\
\text { my future career. }\end{array}$ & 2 & 3 & 2 & 1 & 5 & 1 & 4 & 2 \\
\hline $\begin{array}{l}\text { I don't see the point of } \\
\text { anything we are } \\
\text { learning in Math. }\end{array}$ & 5 & 3 & 2 & 1 & 5 & 3 & 5 & 2 \\
\hline $\begin{array}{l}\text { There's no reason to } \\
\text { learn Math. }\end{array}$ & 5 & 5 & 5 & 0 & 5 & 5 & 5 & 5 \\
\hline Purpose Average & 4 & 3.25 & 3 & 0.75 & 5 & 2.75 & 4.5 & 2.75 \\
\hline $\begin{array}{l}\text { I try hard to do well in } \\
\text { Math. }\end{array}$ & 5 & 4 & 4 & 1 & 5 & 5 & 5 & 3 \\
\hline $\begin{array}{l}\text { When we work on } \\
\text { something in Math, } \\
\text { it's pretty interesting. }\end{array}$ & 5 & 2 & 3 & 1 & 4 & 2 & 3 & 1 \\
\hline $\begin{array}{l}\text { I look forward to } \\
\text { working on my Math } \\
\text { class. }\end{array}$ & 4 & 1 & 2 & 3 & 4 & 1 & 3 & 1 \\
\hline $\begin{array}{l}\text { I don't really care } \\
\text { about doing well in } \\
\text { Math. }\end{array}$ & 5 & 4 & 5 & 1 & 5 & 5 & 5 & 4 \\
\hline $\begin{array}{l}\text { When I have to do } \\
\text { work in my Math } \\
\text { class, I feel bored. }\end{array}$ & 1 & 2 & 3 & 5 & 5 & 2 & 4 & 1 \\
\hline Math scares me. & 4 & 5 & 4 & 1 & 5 & 5 & 5 & 5 \\
\hline $\begin{array}{l}\text { In Math class, I read } \\
\text { the curriculum } \\
\text { carefully }\end{array}$ & 5 & 4 & 4 & 1 & 5 & 5 & 5 & 1 \\
\hline $\begin{array}{l}\text { Engagement } \\
\text { Average }\end{array}$ & 4.14 & 3.14 & 3.57 & 1.86 & 4.71 & 3.57 & 4.29 & 2.29 \\
\hline
\end{tabular}




\begin{tabular}{|c|c|c|c|c|c|c|c|c|}
\hline $\begin{array}{l}\text { If a problem in Math } \\
\text { is really difficult, I } \\
\text { just work harder. }\end{array}$ & 4 & 3 & 4 & 1 & 5 & 5 & 4 & 4 \\
\hline $\begin{array}{l}\text { If I don't do well on a } \\
\text { Math test, I check my } \\
\text { feedback and figure } \\
\text { out how to do better } \\
\text { next time. }\end{array}$ & 5 & 5 & 3 & 1 & 4 & 5 & 5 & 2 \\
\hline $\begin{array}{l}\text { If I don't understand } \\
\text { something in Math, I } \\
\text { ask the teacher for } \\
\text { help. }\end{array}$ & 4 & 5 & 3 & 1 & 4 & 5 & 5 & 1 \\
\hline $\begin{array}{l}\text { If something bad } \\
\text { happens in Math class, } \\
\text { I don't let it get me } \\
\text { down. }\end{array}$ & 4 & 5 & 4 & 1 & 5 & 5 & 5 & 5 \\
\hline $\begin{array}{l}\text { When an assignment } \\
\text { in Math is hard, I put } \\
\text { it off or skip it. }\end{array}$ & 5 & 3 & 4 & 1 & 5 & 4 & 4 & 3 \\
\hline $\begin{array}{l}\text { When I run into a hard } \\
\text { question or problem in } \\
\text { Math class, I get all } \\
\text { confused. }\end{array}$ & 4 & 1 & 3 & 1 & 4 & 4 & 4 & 2 \\
\hline $\begin{array}{l}\text { When I have difficulty } \\
\text { learning something, I } \\
\text { remind myself that } \\
\text { this is important in } \\
\text { reaching my own } \\
\text { personal goals. }\end{array}$ & 5 & 1 & 3 & 1 & 4 & 5 & 5 & 1 \\
\hline $\begin{array}{l}\text { When I don't do well } \\
\text { on a test in Math, I tell } \\
\text { myself it didn't matter. }\end{array}$ & 5 & 2 & 4 & 1 & 5 & 5 & 5 & 3 \\
\hline $\begin{array}{l}\text { If a problem in Math } \\
\text { is really hard, I'll } \\
\text { probably get it wrong. }\end{array}$ & 5 & 2 & 4 & 1 & 5 & 5 & 2 & 3 \\
\hline Resilience Average & 4.56 & 3.00 & 3.56 & 1.00 & 4.56 & 4.78 & 4.33 & 2.67 \\
\hline $\begin{array}{l}\text { Math Overall } \\
\text { Average }\end{array}$ & 4.28 & 2.94 & 3.32 & 1.16 & 4.57 & 3.77 & 4.32 & 2.65 \\
\hline Average A.B. in Math & 0.67 & 2.00 & 2.25 & 2.50 & 3.71 & 4.75 & 17.00 & 5.00 \\
\hline
\end{tabular}




\begin{tabular}{|c|c|c|c|c|c|c|c|c|}
\hline $\begin{array}{l}\text { I am the kind of } \\
\text { person who can } \\
\text { succeed in Science. }\end{array}$ & 5 & 4 & 4 & 3 & 4 & 5 & 3 & 5 \\
\hline $\begin{array}{l}\text { I want to be in a } \\
\text { Science-related field } \\
\text { when I grow up. }\end{array}$ & 5 & 4 & 1 & 2 & 1 & 3 & 3 & 2 \\
\hline $\begin{array}{l}\text { People like me do not } \\
\text { get jobs in Science. }\end{array}$ & 5 & 4 & 5 & 5 & 5 & 5 & 5 & 3 \\
\hline $\begin{array}{l}\text { Science doesn't have } \\
\text { anything to do with } \\
\text { me. }\end{array}$ & 5 & 5 & 4 & 4 & 4 & 5 & 5 & 3 \\
\hline Identity Average & 5 & 4.25 & 3.5 & 3.5 & 3.5 & 4.5 & 4 & 3.25 \\
\hline $\begin{array}{l}\text { Science is a good } \\
\text { place for students like } \\
\text { me. }\end{array}$ & 5 & 3 & 2 & 3 & 3 & 5 & 4 & 4 \\
\hline $\begin{array}{l}\text { Sometimes I feel like I } \\
\text { don't belong in } \\
\text { Science. }\end{array}$ & 5 & 5 & 2 & 1 & 4 & 5 & 5 & 5 \\
\hline Relatedness Average & 5 & 4 & 2 & 2 & 3.5 & 5 & 4.5 & 4.5 \\
\hline I am good at Science. & 5 & 4 & 5 & 1 & 2 & 5 & 4 & 5 \\
\hline $\begin{array}{l}\text { I don't have the brains } \\
\text { to do well in Science. }\end{array}$ & 5 & 4 & 5 & 1 & 5 & 5 & 5 & 5 \\
\hline $\begin{array}{l}\text { If I decide to learn } \\
\text { something hard in } \\
\text { Science, I can do it. }\end{array}$ & 5 & 4 & 5 & 4 & 5 & 5 & 4 & 4 \\
\hline Competence Average & 5.00 & 4.00 & 5.00 & 2.00 & 4.00 & 5.00 & 4.33 & 4.67 \\
\hline $\begin{array}{l}\text { I do my work in } \\
\text { Science because it is } \\
\text { personally important } \\
\text { to me. }\end{array}$ & 5 & 5 & 2 & 2 & 2 & 5 & 4 & 1 \\
\hline $\begin{array}{l}\text { I do my work in } \\
\text { Science because I } \\
\text { have to. }\end{array}$ & 5 & 4 & 3 & 1 & 2 & 1 & 1 & 1 \\
\hline $\begin{array}{l}\text { I do my work in } \\
\text { Science because it is } \\
\text { interesting. }\end{array}$ & 5 & 5 & 3 & 4 & 3 & 5 & 3 & 2 \\
\hline $\begin{array}{l}\text { I do my work in } \\
\text { Science because I } \\
\text { want to do well for } \\
\text { my teacher. }\end{array}$ & 1 & 4 & 3 & 5 & 4 & 1 & 2 & 5 \\
\hline Autonomy Average & 4 & 4.5 & 2.75 & 3 & 2.75 & 3 & 2.5 & 2.25 \\
\hline $\begin{array}{l}\text { I believe that Science } \\
\text { can help make the } \\
\text { world a better place. }\end{array}$ & 5 & 5 & 4 & 5 & 5 & 3 & 4 & 3 \\
\hline
\end{tabular}




\begin{tabular}{|c|c|c|c|c|c|c|c|c|}
\hline $\begin{array}{l}\text { Science is important } \\
\text { for my future career. }\end{array}$ & 5 & 4 & 1 & 5 & 3 & 3 & 4 & 1 \\
\hline $\begin{array}{l}\text { I don't see the point of } \\
\text { anything we are } \\
\text { learning in Science. }\end{array}$ & 5 & 5 & 4 & 2 & 3 & 4 & 5 & 3 \\
\hline $\begin{array}{l}\text { There's no reason to } \\
\text { learn Science. }\end{array}$ & 5 & 5 & 5 & 4 & 5 & 5 & 5 & 5 \\
\hline Purpose Average & 5 & 4.75 & 3.5 & 4 & 4 & 3.75 & 4.5 & 3 \\
\hline $\begin{array}{l}\text { I try hard to do well in } \\
\text { Science. }\end{array}$ & 5 & 2 & 5 & 1 & 4 & 5 & 5 & 2 \\
\hline $\begin{array}{l}\text { When we work on } \\
\text { something in Science, } \\
\text { its pretty interesting. }\end{array}$ & 5 & 5 & 3 & 5 & 2 & 5 & 4 & 2 \\
\hline $\begin{array}{l}\text { I look forward to } \\
\text { doing my Science } \\
\text { work. }\end{array}$ & 5 & 4 & 3 & 1 & 2 & 5 & 3 & 1 \\
\hline $\begin{array}{l}\text { I don't really care } \\
\text { about doing well in } \\
\text { Science. }\end{array}$ & 5 & 5 & 5 & 1 & 5 & 5 & 5 & 3 \\
\hline Science scares me. & 5 & 5 & 5 & 3 & 5 & 5 & 5 & 5 \\
\hline $\begin{array}{l}\text { Engagement } \\
\text { Average }\end{array}$ & 5 & 4.2 & 4.2 & 2.2 & 3.6 & 5 & 4.4 & 2.6 \\
\hline $\begin{array}{l}\text { If a problem in } \\
\text { Science is really } \\
\text { difficult, I just work } \\
\text { harder. }\end{array}$ & 5 & 4 & 5 & 3 & 5 & 5 & 5 & 3 \\
\hline $\begin{array}{l}\text { If I don't do well on a } \\
\text { Science test, I check } \\
\text { my feedback and } \\
\text { figure out how to do } \\
\text { better next time. }\end{array}$ & 5 & 5 & 5 & 3 & 5 & 5 & 5 & 2 \\
\hline $\begin{array}{l}\text { If I don't understand } \\
\text { something in Science, } \\
\text { I ask the teacher for } \\
\text { help. }\end{array}$ & 5 & 5 & 5 & 1 & 4 & 5 & 5 & 1 \\
\hline $\begin{array}{l}\text { If something bad } \\
\text { happens in Science } \\
\text { class, I don't let it get } \\
\text { me down. }\end{array}$ & 5 & 5 & 5 & 1 & 5 & 5 & 5 & 5 \\
\hline $\begin{array}{l}\text { When an assignment } \\
\text { in Science is hard, I } \\
\text { just put it off or skip } \\
\text { it. }\end{array}$ & 5 & 3 & 4 & 1 & 5 & 5 & 4 & 3 \\
\hline
\end{tabular}




\begin{tabular}{|c|c|c|c|c|c|c|c|c|}
\hline $\begin{array}{l}\text { When I run into a hard } \\
\text { question or problem in } \\
\text { Science class, I get all } \\
\text { confused. }\end{array}$ & 5 & 4 & 4 & 1 & 5 & 4 & 3 & 3 \\
\hline $\begin{array}{l}\text { When I don't } \\
\text { understand something } \\
\text { in Science, I feel like } \\
\text { it's all my fault. }\end{array}$ & 4 & 5 & 5 & 1 & 5 & 4 & 3 & 3 \\
\hline $\begin{array}{l}\text { When I don't do well } \\
\text { on a test in Science, I } \\
\text { tell myself it didn't } \\
\text { matter. }\end{array}$ & 5 & 3 & 5 & 1 & 5 & 5 & 4 & 3 \\
\hline $\begin{array}{l}\text { If a problem in } \\
\text { Science is really hard, } \\
\text { I'll probably get it } \\
\text { wrong. }\end{array}$ & 5 & 4 & 5 & 1 & 5 & 5 & 3 & 3 \\
\hline Resiliency Average & 4.89 & 4.22 & 4.78 & 1.44 & 4.89 & 4.78 & 4.11 & 2.89 \\
\hline $\begin{array}{l}\text { Overall Science } \\
\text { Average }\end{array}$ & 4.84 & 4.29 & 3.89 & 2.48 & 3.90 & 4.45 & 4.04 & 3.14 \\
\hline $\begin{array}{l}\text { Average A.B. in } \\
\text { Science }\end{array}$ & 0.00 & -2.00 & 0.72 & 1.25 & 0.75 & & 6.00 & 4.25 \\
\hline $\begin{array}{l}\text { If I have a problem } \\
\text { with technology, I just } \\
\text { work harder and I'll } \\
\text { figure it out. }\end{array}$ & 5 & 5 & 3 & 1 & 5 & 4 & 5 & 4 \\
\hline $\begin{array}{l}\text { If I have a } \\
\text { technological issue, I } \\
\text { ask a teacher for help. }\end{array}$ & 5 & 2 & 3 & 3 & 4 & 5 & 5 & 3 \\
\hline $\begin{array}{l}\text { If a piece of } \\
\text { technology JUST } \\
\text { ISN'T WORKING, I } \\
\text { don't let it get me } \\
\text { down. }\end{array}$ & 5 & 5 & 4 & 1 & 5 & 4 & 5 & 2 \\
\hline $\begin{array}{l}\text { When I don't } \\
\text { understand something } \\
\text { technological, I feel } \\
\text { like it's all my fault. }\end{array}$ & 5 & 5 & 5 & 5 & 5 & 5 & 3 & 5 \\
\hline $\begin{array}{l}\text { When I have trouble } \\
\text { with technology, I } \\
\text { usually figure it out in } \\
\text { the end. }\end{array}$ & 5 & 5 & 2 & 4 & 5 & 5 & 4 & 5 \\
\hline $\begin{array}{l}\text { If a technological } \\
\text { problem is really hard, } \\
\text { I probably couldn't } \\
\text { solve it. }\end{array}$ & 4 & 5 & 2 & 1 & 5 & 5 & 5 & 4 \\
\hline Resilience Average & 4.83 & 4.50 & 3.17 & 2.50 & 4.83 & 4.67 & 4.50 & 3.83 \\
\hline
\end{tabular}




\begin{tabular}{|c|c|c|c|c|c|c|c|c|}
\hline $\begin{array}{l}\text { I am the kind of } \\
\text { person who can } \\
\text { succeed in a } \\
\text { technological field. }\end{array}$ & 5 & 4 & 2 & 1 & 5 & 4 & 4 & 5 \\
\hline $\begin{array}{l}\text { I want to be involved } \\
\text { with technology when } \\
\text { I grow up. }\end{array}$ & 3 & 4 & 1 & 1 & 4 & 1 & & 1 \\
\hline $\begin{array}{l}\text { People like me do not } \\
\text { get jobs in the } \\
\text { technology sector. }\end{array}$ & 4 & 4 & 4 & 1 & 5 & 5 & 5 & 4 \\
\hline $\begin{array}{l}\text { Technology doesn't } \\
\text { have anything to do } \\
\text { with me. }\end{array}$ & 5 & 5 & 4 & 3 & 5 & 5 & 5 & 4 \\
\hline Identity Average & 4.25 & 4.25 & 2.75 & 1.5 & 4.75 & 3.75 & 4.67 & 3.5 \\
\hline $\begin{array}{l}\text { I am good at } \\
\text { technology. }\end{array}$ & 5 & 5 & 3 & 3 & 5 & 3 & 3 & 5 \\
\hline $\begin{array}{l}\text { I don't have the brains } \\
\text { to understand } \\
\text { technology. }\end{array}$ & 5 & 5 & 4 & 1 & 5 & 5 & 5 & 5 \\
\hline $\begin{array}{l}\text { I can figure out } \\
\text { technology if I want } \\
\text { to. }\end{array}$ & 5 & 5 & 4 & 4 & 5 & 5 & 5 & 5 \\
\hline $\begin{array}{l}\text { If I decide to learn } \\
\text { technology that's } \\
\text { difficult, I can do it. }\end{array}$ & 5 & 4 & 3 & 4 & 5 & 5 & 5 & 5 \\
\hline $\begin{array}{l}\text { I am not very good at } \\
\text { technology. }\end{array}$ & 4 & 5 & 3 & 1 & 5 & 4 & 4 & 5 \\
\hline Competence Average & 4.8 & 4.8 & 3.4 & 2.6 & 5 & 4.4 & 4.4 & 5 \\
\hline $\begin{array}{l}\text { Technology is } \\
\text { important for my } \\
\text { future career. }\end{array}$ & 4 & 4 & 2 & 1 & 5 & 3 & 4 & 1 \\
\hline $\begin{array}{l}\text { I don't see the point of } \\
\text { learning technology. }\end{array}$ & 5 & 5 & 5 & 1 & 5 & 5 & 5 & 5 \\
\hline Purpose Average & 4.5 & 4.5 & 3.5 & 1 & 5 & 4 & 4.5 & 3 \\
\hline Tech Average & 4.64 & 4.53 & 3.18 & 2.08 & 4.88 & 4.28 & 4.50 & 3.97 \\
\hline $\begin{array}{l}\text { Average A.B. in all } \\
\text { classes }\end{array}$ & 0.00 & 0.76 & 0.85 & 1.40 & 2.39 & 2.50 & 4.46 & 4.48 \\
\hline
\end{tabular}

Table A-13. Bottom 7 High Schoolers by total average assignments behind:

\begin{tabular}{|l|r|l|l|l|l|l|r|}
\hline Statement: & Zz13 & Zz09 & Zz14 & Zz04 & Zz23 & Zz16 & Zz08 \\
\hline $\begin{array}{l}\text { I am the kind of } \\
\begin{array}{l}\text { person who can } \\
\text { succeed in Math. }\end{array}\end{array}$ & & & & & & & \\
\hline
\end{tabular}




\begin{tabular}{|c|c|c|c|c|c|c|c|}
\hline $\begin{array}{l}\text { I want to be in a } \\
\text { Math-related career } \\
\text { when I grow up. }\end{array}$ & 4 & 1 & 1 & 1 & 3 & 1 & 1 \\
\hline $\begin{array}{l}\text { People like me do not } \\
\text { get jobs in Math. }\end{array}$ & 3 & 2 & 5 & 3 & 4 & 2 & 5 \\
\hline $\begin{array}{l}\text { Math doesn't have } \\
\text { anything to do with } \\
\text { my life. }\end{array}$ & 5 & 3 & 3 & 3 & 5 & 4 & 5 \\
\hline Identity Average & 3.5 & 1.75 & 3.25 & 2.75 & 4 & 2.5 & 3 \\
\hline $\begin{array}{l}\text { Math class is a good } \\
\text { place for students like } \\
\text { me. }\end{array}$ & 5 & 1 & 2 & 1 & 4 & 1 & 1 \\
\hline $\begin{array}{l}\text { Sometimes I feel like } \\
\text { I don't belong in } \\
\text { Math. }\end{array}$ & 3 & 1 & 3 & 2 & 5 & 2 & 1 \\
\hline $\begin{array}{l}\text { Relatedness } \\
\text { Average }\end{array}$ & 4 & 1 & 2.5 & 1.5 & 4.5 & 1.5 & 1 \\
\hline I am good at Math. & 2 & 2 & 3 & 3 & 4 & 2 & 2 \\
\hline $\begin{array}{l}\text { I don't have the } \\
\text { brains to do well in } \\
\text { Math. }\end{array}$ & 3 & 3 & 5 & 5 & 5 & 5 & 3 \\
\hline $\begin{array}{l}\text { Competence } \\
\text { Average }\end{array}$ & 2.5 & 2.5 & 4 & 4 & 4.5 & 3.5 & 2.5 \\
\hline $\begin{array}{l}\text { I do my work in Math } \\
\text { because it is } \\
\text { personally important } \\
\text { to me. }\end{array}$ & 2 & 2 & 4 & 2 & 2 & 1 & 1 \\
\hline $\begin{array}{l}\text { I do my work in Math } \\
\text { because they make us } \\
\text { do it. }\end{array}$ & 2 & 1 & 1 & 2 & 4 & 2 & 2 \\
\hline $\begin{array}{l}\text { I do my work in Math } \\
\text { because I want to do } \\
\text { well for my teacher }\end{array}$ & 3 & 2 & 3 & 2 & 3 & 3 & 1 \\
\hline Autonomy Average & 2.33 & 1.67 & 2.67 & 2.00 & 3.00 & 2.00 & 1.33 \\
\hline $\begin{array}{l}\text { I believe that Math } \\
\text { can help make the } \\
\text { world a better place. }\end{array}$ & 5 & 3 & 1 & 1 & 4 & 2 & 1 \\
\hline $\begin{array}{l}\text { Math is important for } \\
\text { my future career. }\end{array}$ & 5 & 1 & 2 & 1 & 4 & 2 & 1 \\
\hline $\begin{array}{l}\text { I don't see the point } \\
\text { of anything we are } \\
\text { learning in Math. }\end{array}$ & 4 & 3 & 2 & 4 & 5 & 5 & 1 \\
\hline
\end{tabular}




\begin{tabular}{|c|c|c|c|c|c|c|c|}
\hline $\begin{array}{l}\text { There's no reason to } \\
\text { learn Math. }\end{array}$ & 5 & 3 & 4 & 5 & 5 & 5 & 2 \\
\hline Purpose Average & 4.75 & 2.5 & 2.25 & 2.75 & 4.5 & 3.5 & 1.25 \\
\hline $\begin{array}{l}\text { I try hard to do well } \\
\text { in Math. }\end{array}$ & 2 & 4 & 5 & 3 & 5 & 2 & 3 \\
\hline $\begin{array}{l}\text { When we work on } \\
\text { something in Math, } \\
\text { it's pretty interesting. }\end{array}$ & 1 & 1 & 1 & 1 & 3 & 1 & 1 \\
\hline $\begin{array}{l}\text { I look forward to } \\
\text { working on my Math } \\
\text { class. }\end{array}$ & 1 & 2 & 1 & 1 & 3 & 1 & 1 \\
\hline $\begin{array}{l}\text { I don't really care } \\
\text { about doing well in } \\
\text { Math. }\end{array}$ & 4 & 3 & 5 & 3 & 5 & 4 & 4 \\
\hline $\begin{array}{l}\text { When I have to do } \\
\text { work in my Math } \\
\text { class, I feel bored. }\end{array}$ & 4 & 1 & 1 & 2 & 3 & 2 & 1 \\
\hline Math scares me. & 3 & 5 & 4 & 5 & 3 & 5 & 2 \\
\hline $\begin{array}{l}\text { In Math class, I read } \\
\text { the curriculum } \\
\text { carefully }\end{array}$ & 2 & 4 & 4 & 3 & 3 & 1 & 1 \\
\hline $\begin{array}{l}\text { Engagement } \\
\text { Average }\end{array}$ & 2.43 & 2.86 & 3.00 & 2.57 & 3.57 & 2.29 & 1.86 \\
\hline $\begin{array}{l}\text { If a problem in Math } \\
\text { is really difficult, I } \\
\text { just work harder. }\end{array}$ & 2 & 2 & 5 & 3 & 4 & 3 & 1 \\
\hline $\begin{array}{l}\text { If I don't do well on a } \\
\text { Math test, I check my } \\
\text { feedback and figure } \\
\text { out how to do better } \\
\text { next time. }\end{array}$ & 3 & 5 & 5 & 2 & 4 & 3 & 1 \\
\hline $\begin{array}{l}\text { If I don't understand } \\
\text { something in Math, I } \\
\text { ask the teacher for } \\
\text { help. }\end{array}$ & 4 & 3 & 5 & 3 & 4 & 1 & 1 \\
\hline $\begin{array}{l}\text { If something bad } \\
\text { happens in Math } \\
\text { class, I don't let it get } \\
\text { me down. }\end{array}$ & 5 & 3 & 5 & 4 & 5 & 2 & 1 \\
\hline $\begin{array}{l}\text { When an assignment } \\
\text { in Math is hard, I put } \\
\text { it off or skip it. }\end{array}$ & 4 & 2 & 4 & 1 & 4 & 3 & 1 \\
\hline
\end{tabular}




\begin{tabular}{|c|c|c|c|c|c|c|c|}
\hline $\begin{array}{l}\text { When I run into a } \\
\text { hard question or } \\
\text { problem in Math } \\
\text { class, I get all } \\
\text { confused. }\end{array}$ & 3 & 1 & 3 & 4 & 1 & 3 & 1 \\
\hline $\begin{array}{l}\text { When I have } \\
\text { difficulty learning } \\
\text { something, I remind } \\
\text { myself that this is } \\
\text { important in reaching } \\
\text { my own personal } \\
\text { goals. }\end{array}$ & 2 & 3 & 2 & 1 & 3 & 1 & 1 \\
\hline $\begin{array}{l}\text { When I don't do well } \\
\text { on a test in Math, I } \\
\text { tell myself it didn't } \\
\text { matter. }\end{array}$ & 4 & 3 & 5 & 4 & 3 & 3 & 5 \\
\hline $\begin{array}{l}\text { If a problem in Math } \\
\text { is really hard, I'll } \\
\text { probably get it } \\
\text { wrong. }\end{array}$ & 3 & 2 & 5 & 5 & 3 & 3 & 1 \\
\hline Resilience Average & 3.33 & 2.67 & 4.33 & 3.00 & 3.44 & 2.44 & 1.44 \\
\hline $\begin{array}{l}\text { Math Overall } \\
\text { Average }\end{array}$ & 3.20 & 2.38 & 3.29 & 2.69 & 3.78 & 2.52 & 1.60 \\
\hline $\begin{array}{l}\text { Average A.B. in } \\
\text { Math }\end{array}$ & 15.50 & 7.00 & 11.67 & 7.50 & 28.00 & 32.50 & 45.50 \\
\hline $\begin{array}{l}\text { I am the kind of } \\
\text { person who can } \\
\text { succeed in Science. }\end{array}$ & 1 & 4 & 5 & 1 & 3 & 4 & 2 \\
\hline $\begin{array}{l}\text { I want to be in a } \\
\text { Science-related field } \\
\text { when I grow up. }\end{array}$ & 3 & 1 & 4 & 1 & 1 & 1 & 5 \\
\hline $\begin{array}{l}\text { People like me do not } \\
\text { get jobs in Science. }\end{array}$ & 1 & 3 & 5 & 2 & 3 & 5 & 4 \\
\hline $\begin{array}{l}\text { Science doesn't have } \\
\text { anything to do with } \\
\text { me. }\end{array}$ & 2 & 4 & 4 & 1 & 4 & 5 & 4 \\
\hline Identity Average & 1.75 & 3 & 4.5 & 1.25 & 2.75 & 3.75 & 3.75 \\
\hline $\begin{array}{l}\text { Science is a good } \\
\text { place for students like } \\
\text { me. }\end{array}$ & 2 & 1 & 3 & 1 & 2 & 2 & 1 \\
\hline $\begin{array}{l}\text { Sometimes I feel like } \\
\text { I don't belong in } \\
\text { Science. }\end{array}$ & 1 & 2 & 5 & 3 & 4 & 5 & 3 \\
\hline $\begin{array}{l}\text { Relatedness } \\
\text { Average }\end{array}$ & 1.5 & 1.5 & 4 & 2 & 3 & 3.5 & 2 \\
\hline I am good at Science. & 1 & 3 & 5 & 1 & 2 & 3 & 2 \\
\hline
\end{tabular}




\begin{tabular}{|c|c|c|c|c|c|c|c|}
\hline $\begin{array}{l}\text { I don't have the } \\
\text { brains to do well in } \\
\text { Science. }\end{array}$ & 1 & 5 & 5 & 3 & 5 & 5 & 4 \\
\hline $\begin{array}{l}\text { If I decide to learn } \\
\text { something hard in } \\
\text { Science, I can do it. }\end{array}$ & 2 & 4 & 5 & 4 & 3 & 3 & 2 \\
\hline $\begin{array}{l}\text { Competence } \\
\text { Average }\end{array}$ & 1.33 & 4.00 & 5.00 & 2.67 & 3.33 & 3.67 & 2.67 \\
\hline $\begin{array}{l}\text { I do my work in } \\
\text { Science because it is } \\
\text { personally important } \\
\text { to me. }\end{array}$ & 1 & 3 & 5 & 1 & 3 & 2 & 1 \\
\hline $\begin{array}{l}\text { I do my work in } \\
\text { Science because I } \\
\text { have to. }\end{array}$ & 1 & 1 & 1 & 1 & 2 & 2 & 4 \\
\hline $\begin{array}{l}\text { I do my work in } \\
\text { Science because it is } \\
\text { interesting. }\end{array}$ & 3 & 2 & 4 & 1 & 4 & 3 & 1 \\
\hline $\begin{array}{l}\text { I do my work in } \\
\text { Science because I } \\
\text { want to do well for } \\
\text { my teacher. }\end{array}$ & 4 & 4 & 3 & 4 & 2 & 3 & 5 \\
\hline Autonomy Average & 2.25 & 2.5 & 3.25 & 1.75 & 2.75 & 2.5 & 2.75 \\
\hline $\begin{array}{l}\text { I believe that Science } \\
\text { can help make the } \\
\text { world a better place. }\end{array}$ & 5 & 3 & 4 & 3 & 4 & 4 & 1 \\
\hline $\begin{array}{l}\text { Science is important } \\
\text { for my future career. }\end{array}$ & 3 & 1 & 5 & 1 & 2 & 1 & 5 \\
\hline $\begin{array}{l}\text { I don't see the point } \\
\text { of anything we are } \\
\text { learning in Science. }\end{array}$ & 2 & 3 & 5 & 2 & 5 & 5 & 2 \\
\hline $\begin{array}{l}\text { There's no reason to } \\
\text { learn Science. }\end{array}$ & 2 & 4 & 5 & 5 & 4 & 5 & 3 \\
\hline Purpose Average & 3 & 2.75 & 4.75 & 2.75 & 3.75 & 3.75 & 2.75 \\
\hline $\begin{array}{l}\text { I try hard to do well } \\
\text { in Science. }\end{array}$ & 2 & 5 & 4 & 2 & 4 & 3 & 2 \\
\hline $\begin{array}{l}\text { When we work on } \\
\text { something in Science, } \\
\text { its pretty interesting. }\end{array}$ & 2 & 3 & 4 & 2 & 1 & 4 & 3 \\
\hline $\begin{array}{l}\text { I look forward to } \\
\text { doing my Science } \\
\text { work. }\end{array}$ & 1 & 2 & 4 & 1 & 3 & 2 & 1 \\
\hline
\end{tabular}




\begin{tabular}{|c|c|c|c|c|c|c|c|}
\hline $\begin{array}{l}\text { I don't really care } \\
\text { about doing well in } \\
\text { Science. }\end{array}$ & 2 & 4 & 5 & 2 & 3 & 5 & 2 \\
\hline Science scares me. & 2 & 5 & 5 & 5 & 3 & 5 & 3 \\
\hline $\begin{array}{l}\text { Engagement } \\
\text { Average }\end{array}$ & 1.8 & 3.8 & 4.4 & 2.4 & 2.8 & 3.8 & 2.2 \\
\hline $\begin{array}{l}\text { If a problem in } \\
\text { Science is really } \\
\text { difficult, I just work } \\
\text { harder. }\end{array}$ & 2 & 2 & 5 & 2 & 2 & 2 & 2 \\
\hline $\begin{array}{l}\text { If I don't do well on a } \\
\text { Science test, I check } \\
\text { my feedback and } \\
\text { figure out how to do } \\
\text { better next time. }\end{array}$ & 3 & 5 & 5 & 2 & 4 & 2 & 1 \\
\hline $\begin{array}{l}\text { If I don't understand } \\
\text { something in Science, } \\
\text { I ask the teacher for } \\
\text { help. }\end{array}$ & 3 & 4 & 5 & 3 & 4 & 3 & 2 \\
\hline $\begin{array}{l}\text { If something bad } \\
\text { happens in Science } \\
\text { class, I don't let it get } \\
\text { me down. }\end{array}$ & 5 & 5 & 5 & 5 & 5 & 2 & 1 \\
\hline $\begin{array}{l}\text { When an assignment } \\
\text { in Science is hard, I } \\
\text { just put it off or skip } \\
\text { it. }\end{array}$ & 2 & 4 & 2 & 1 & 4 & 4 & 1 \\
\hline $\begin{array}{l}\text { When I run into a } \\
\text { hard question or } \\
\text { problem in Science } \\
\text { class, I get all } \\
\text { confused. }\end{array}$ & 2 & 4 & 2 & 3 & 3 & 5 & 1 \\
\hline $\begin{array}{l}\text { When I don't } \\
\text { understand something } \\
\text { in Science, I feel like } \\
\text { it's all my fault. }\end{array}$ & 5 & 5 & 5 & 2 & 4 & 4 & 1 \\
\hline $\begin{array}{l}\text { When I don't do well } \\
\text { on a test in Science, I } \\
\text { tell myself it didn't } \\
\text { matter. }\end{array}$ & 4 & 4 & 5 & 5 & 5 & 5 & 3 \\
\hline $\begin{array}{l}\text { If a problem in } \\
\text { Science is really } \\
\text { hard, I'll probably get } \\
\text { it wrong. }\end{array}$ & 3 & 2 & 5 & 4 & 4 & 5 & 1 \\
\hline Resiliency Average & 3.22 & 3.89 & 4.33 & 3.00 & 3.89 & 3.56 & 1.44 \\
\hline $\begin{array}{l}\text { Overall Science } \\
\text { Average }\end{array}$ & 2.31 & 3.25 & 4.32 & 2.36 & 3.27 & 3.51 & 2.38 \\
\hline
\end{tabular}




\begin{tabular}{|c|c|c|c|c|c|c|c|}
\hline $\begin{array}{l}\text { Average A.B. in } \\
\text { Science }\end{array}$ & 6.00 & 6.50 & 11.25 & 7.50 & 10.50 & 22.00 & 16.50 \\
\hline $\begin{array}{l}\text { If I have a problem } \\
\text { with technology, I } \\
\text { just work harder and } \\
\text { I'll figure it out. }\end{array}$ & 5 & 3 & 4 & 5 & 4 & 1 & 1 \\
\hline $\begin{array}{l}\text { If I have a } \\
\text { technological issue, I } \\
\text { ask a teacher for help. }\end{array}$ & 4 & 4 & 5 & 2 & 4 & 2 & 1 \\
\hline $\begin{array}{l}\text { If a piece of } \\
\text { technology JUST } \\
\text { ISN'T WORKING, I } \\
\text { don't let it get me } \\
\text { down. }\end{array}$ & 2 & 4 & 5 & 4 & 4 & 1 & 1 \\
\hline $\begin{array}{l}\text { When I don't } \\
\text { understand something } \\
\text { technological, I feel } \\
\text { like it's all my fault. }\end{array}$ & 5 & 4 & 5 & 3 & 5 & 5 & 1 \\
\hline $\begin{array}{l}\text { When I have trouble } \\
\text { with technology, I } \\
\text { usually figure it out } \\
\text { in the end. }\end{array}$ & 5 & 3 & 3 & 4 & 3 & 1 & 1 \\
\hline $\begin{array}{l}\text { If a technological } \\
\text { problem is really } \\
\text { hard, I probably } \\
\text { couldn't solve it. }\end{array}$ & 5 & 1 & 5 & 3 & 4 & 5 & 1 \\
\hline Resilience Average & 4.33 & 3.17 & 4.50 & 3.50 & 4.00 & 2.50 & 1.00 \\
\hline $\begin{array}{l}\text { I am the kind of } \\
\text { person who can } \\
\text { succeed in a } \\
\text { technological field. }\end{array}$ & 4 & 1 & 2 & 4 & 3 & 2 & 1 \\
\hline $\begin{array}{l}\text { I want to be involved } \\
\text { with technology } \\
\text { when I grow up. }\end{array}$ & 5 & 1 & 3 & 1 & 3 & 2 & 1 \\
\hline $\begin{array}{l}\text { People like me do not } \\
\text { get jobs in the } \\
\text { technology sector. }\end{array}$ & 5 & 1 & 5 & 4 & 5 & 5 & 1 \\
\hline $\begin{array}{l}\text { Technology doesn't } \\
\text { have anything to do } \\
\text { with me. }\end{array}$ & 5 & 3 & 4 & 5 & 5 & 5 & 4 \\
\hline Identity Average & 4.75 & 1.5 & 3.5 & 3.5 & 4 & 3.5 & 1.75 \\
\hline $\begin{array}{l}\text { I am good at } \\
\text { technology. }\end{array}$ & 4 & 2 & 3 & 5 & 4 & 1 & 1 \\
\hline $\begin{array}{l}\text { I don't have the } \\
\text { brains to understand } \\
\text { technology. }\end{array}$ & 5 & 4 & 5 & 4 & 4 & 5 & 1 \\
\hline
\end{tabular}




\begin{tabular}{|c|c|c|c|c|c|c|c|}
\hline $\begin{array}{l}\text { I can figure out } \\
\text { technology if I want } \\
\text { to. }\end{array}$ & 4 & 4 & 5 & 5 & 4 & 3 & 3 \\
\hline $\begin{array}{l}\text { If I decide to learn } \\
\text { technology that's } \\
\text { difficult, I can do it. }\end{array}$ & 4 & 3 & 5 & 4 & 3 & 3 & 1 \\
\hline $\begin{array}{l}\text { I am not very good at } \\
\text { technology. }\end{array}$ & 5 & 2 & 3 & 4 & 5 & 2 & 2 \\
\hline $\begin{array}{l}\text { Competence } \\
\text { Average } \\
\end{array}$ & 4.4 & 3 & 4.2 & 4.4 & 4 & 2.8 & 1.6 \\
\hline $\begin{array}{l}\text { Technology is } \\
\text { important for my } \\
\text { future career. }\end{array}$ & 5 & 1 & 1 & 1 & 5 & 2 & 1 \\
\hline $\begin{array}{l}\text { I don't see the point } \\
\text { of learning } \\
\text { technology. }\end{array}$ & 5 & 3 & 4 & 5 & 5 & 5 & 1 \\
\hline Purpose Average & 5 & 2 & 2.5 & 3 & 5 & 3.5 & 1 \\
\hline Tech Average & 4.55 & 2.56 & 3.89 & 3.69 & 4.14 & 2.97 & 1.35 \\
\hline $\begin{array}{l}\text { Average A.B. in all } \\
\text { classes }\end{array}$ & 6.00 & 7.16 & 10.54 & 10.86 & 13.10 & 21.00 & 25.06 \\
\hline
\end{tabular}




\section{Appendix B-4 Student Survey of Teacher Practices and Relationship}

Table A-14. First half of survey on Motivational Practices Prompt: How Motivating do you find it when your teacher...

\begin{tabular}{|c|c|c|c|c|c|}
\hline Scale: & $\begin{array}{c}\text { My teacher } \\
\text { doesn't do } \\
\text { this }\end{array}$ & $\begin{array}{c}\text { This } \\
\text { discourages } \\
\text { me }\end{array}$ & $\begin{array}{c}\text { This is not } \\
\text { motivational }\end{array}$ & $\begin{array}{c}\text { I'm motivated } \\
\text { by this }\end{array}$ & $\begin{array}{c}\text { This really } \\
\text { motivates me }\end{array}$ \\
\hline & 1 & 2 & 3 & 4 & 5 \\
\hline
\end{tabular}

\begin{tabular}{|c|c|c|c|}
\hline & Question: & Zz22 & Zz18 \\
\hline Category & $\begin{array}{l}\text { Who is your } \\
\text { Math teacher? }\end{array}$ & Diphily & Diphily \\
\hline \multirow{5}{*}{$\begin{array}{c}\text { Individual } \\
\text { Contact }\end{array}$} & Texts you & 1 & 1 \\
\hline & Calls you & 1 & 3 \\
\hline & $\begin{array}{l}\text { E mails you } \\
\text { directly }\end{array}$ & 4 & 4 \\
\hline & $\begin{array}{l}\text { Quickly answers } \\
\text { your e mails }\end{array}$ & 5 & 1 \\
\hline & $\begin{array}{l}\text { Contacts you } \\
\text { because you } \\
\text { haven't been } \\
\text { working }\end{array}$ & 1 & 3 \\
\hline $\begin{array}{l}\text { Parent } \\
\text { Contact }\end{array}$ & $\begin{array}{l}\text { Texts or calls } \\
\text { your parents }\end{array}$ & 1 & 1 \\
\hline $\begin{array}{l}\text { Teacher } \\
\text { Presence }\end{array}$ & $\begin{array}{c}\text { Is available } \\
\text { during Virtual lab } \\
\text { times }\end{array}$ & 5 & 4 \\
\hline
\end{tabular}

\begin{tabular}{|c|c|c|}
\hline Question: & Zz18 & Zz08 \\
\hline $\begin{array}{l}\text { Who is your } \\
\text { Science teacher? }\end{array}$ & $\begin{array}{l}\text { Barrentine } \\
\text { and } \\
\text { Everett }\end{array}$ & Barrentine \\
\hline Texts you & 4 & 4 \\
\hline Calls you & 4 & 4 \\
\hline $\begin{array}{l}\text { E mails you } \\
\text { directly }\end{array}$ & 4 & 4 \\
\hline $\begin{array}{l}\quad \text { Quickly } \\
\text { answers your e } \\
\text { mails }\end{array}$ & 4 & 4 \\
\hline $\begin{array}{l}\text { Contacts you } \\
\text { because you } \\
\text { haven't been } \\
\text { working }\end{array}$ & 4 & 4 \\
\hline $\begin{array}{l}\text { Texts or calls } \\
\text { your parents }\end{array}$ & 1 & 4 \\
\hline $\begin{array}{l}\text { Is available } \\
\text { during Virtual lab } \\
\text { times }\end{array}$ & 4 & 3 \\
\hline
\end{tabular}




\begin{tabular}{|c|c|c|c|c|c|c|}
\hline & $\begin{array}{l}\text { Makes videos of } \\
\text { him } / \text { herself }\end{array}$ & 4 & 1 & $\begin{array}{l}\text { Makes videos } \\
\text { of him/herself }\end{array}$ & 1 & 3 \\
\hline & $\begin{array}{c}\text { Posts } \\
\text { announcements in } \\
\text { Brainhoney }\end{array}$ & 4 & 3 & \begin{tabular}{l}
\multicolumn{1}{c}{ Posts } \\
announcements in \\
Brainhoney
\end{tabular} & 1 & 4 \\
\hline & Updates a Blog & 5 & 1 & Updates a Blog & 1 & 2 \\
\hline & $\begin{array}{c}\text { Is available } \\
\text { during physical } \\
\text { lab times }\end{array}$ & 5 & 4 & $\begin{array}{l}\text { Is available } \\
\text { during physical } \\
\text { lab times }\end{array}$ & 4 & 1 \\
\hline \multirow{5}{*}{$\begin{array}{c}\text { Improving } \\
\text { Class } \\
\text { Experience }\end{array}$} & $\begin{array}{l}\text { Makes videos of } \\
\text { your class }\end{array}$ & 1 & 1 & $\begin{array}{l}\text { Makes videos } \\
\text { of your class }\end{array}$ & 1 & 3 \\
\hline & $\begin{array}{l}\text { Writes his/her } \\
\text { own curriculum }\end{array}$ & 4 & 1 & $\begin{array}{l}\text { Writes his/her } \\
\text { own curriculum }\end{array}$ & 4 & 1 \\
\hline & $\begin{array}{c}\text { Makes a } \\
\text { template for an } \\
\text { assignment }\end{array}$ & 4 & 1 & $\begin{array}{l}\text { Makes a } \\
\text { template for an } \\
\text { assignment }\end{array}$ & 3 & 3 \\
\hline & $\begin{array}{l}\text { Runs a specific } \\
\text { lab in the } \\
\text { building }\end{array}$ & 5 & 4 & $\begin{array}{l}\text { Runs a specific } \\
\text { lab in the building }\end{array}$ & 4 & 1 \\
\hline & $\begin{array}{c}\text { Conducts a } \\
\text { Virtual Lecture at } \\
\text { a set time }\end{array}$ & 5 & 4 & $\begin{array}{l}\text { Conducts a } \\
\text { Virtual Lecture at } \\
\text { a set time }\end{array}$ & 4 & 1 \\
\hline \multirow{2}{*}{ Grading: } & $\begin{array}{l}\text { Grades within a } \\
\text { day }\end{array}$ & 5 & 1 & $\begin{array}{l}\text { Grades within a } \\
\text { day }\end{array}$ & 3 & 4 \\
\hline & $\begin{array}{l}\text { Grades within } 2 \\
\text { days }\end{array}$ & 5 & 1 & $\begin{array}{l}\text { Grades within } 2 \\
\text { days }\end{array}$ & 2 & 4 \\
\hline
\end{tabular}




\begin{tabular}{|c|c|c|c|c|c|c|}
\hline & $\begin{array}{l}\text { Automatically } \\
\text { allows retrys on } \\
\text { low grade } \\
\text { assignments }\end{array}$ & 5 & 4 & $\begin{array}{l}\text { Automatically } \\
\text { allows retrys on } \\
\text { low grade } \\
\text { assignments }\end{array}$ & 3 & 1 \\
\hline \multirow{3}{*}{ Other: } & $\begin{array}{l}\text { Schedules a } \\
\text { meeting with you } \\
\text { in person }\end{array}$ & 5 & 1 & $\begin{array}{l}\text { Schedules a } \\
\text { meeting with you } \\
\text { in person }\end{array}$ & 3 & 2 \\
\hline & $\begin{array}{l}\text { Asks you about } \\
\text { your personal life }\end{array}$ & 4 & 1 & $\begin{array}{l}\text { Asks you about } \\
\text { your personal life }\end{array}$ & 3 & 1 \\
\hline & $\begin{array}{c}\text { Uses } \\
\text { encouraging } \\
\text { language when } \\
\text { grading } \\
\text { assignments }\end{array}$ & 4 & 1 & $\begin{array}{l}\quad \text { Uses } \\
\text { encouraging } \\
\text { language when } \\
\text { grading } \\
\text { assignments }\end{array}$ & 4 & 1 \\
\hline
\end{tabular}

Table A-15. Second half of survey, on Teacher-Student Relationship

\begin{tabular}{|c|c|c|c|c|c|}
\hline Scale: & $\begin{array}{l}\text { I don't know } \\
\text { / can't tell }\end{array}$ & $\begin{array}{c}\text { Not at all } \\
\text { true }\end{array}$ & $\begin{array}{l}\text { A little bit } \\
\text { true }\end{array}$ & Fairly true & Totally true \\
\hline & 1 & 2 & 3 & 4 & 5 \\
\hline
\end{tabular}

Colored Text represents a negative statement, the score was inverted for those:

\begin{tabular}{|l|l|l|}
\hline Student: & Zz22 & Zz18 \\
\hline $\begin{array}{l}\text { Who is your } \\
\text { Math teacher? }\end{array}$ & Diphily & Diphily \\
\hline $\begin{array}{l}\text { My Math } \\
\text { Teacher likes me. }\end{array}$ & 5 & 3 \\
\hline & & \\
$\begin{array}{l}\text { My Math } \\
\text { Teacher } \\
\text { appreciates and } \\
\text { respects me. }\end{array}$ & & \\
\hline
\end{tabular}

\begin{tabular}{|l|l|l|}
\hline & Zz18 & Zz08 \\
\hline $\begin{array}{l}\text { Who is your Science } \\
\text { teacher? }\end{array}$ & $\begin{array}{l}\text { Barrentine } \\
\text { and Everett }\end{array}$ & Barrentine \\
\hline $\begin{array}{l}\text { My Science Teacher } \\
\text { likes me. }\end{array}$ & & \\
\hline & & \\
$\begin{array}{l}\text { My Science Teacher } \\
\text { appreciates and respects } \\
\text { me. }\end{array}$ & & \\
\hline
\end{tabular}




\begin{tabular}{|c|c|c|}
\hline $\begin{array}{l}\text { My Math } \\
\text { Teacher doesn't } \\
\text { understand me. }\end{array}$ & 4 & 5 \\
\hline $\begin{array}{l}\text { My Math } \\
\text { Teacher doesn't } \\
\text { even know who I } \\
\text { am }\end{array}$ & 4 & 4 \\
\hline $\begin{array}{l}\text { My Math } \\
\text { Teacher really } \\
\text { cares about me. }\end{array}$ & 4 & 4 \\
\hline $\begin{array}{l}\text { My Math } \\
\text { Teacher is never } \\
\text { there for me. }\end{array}$ & 4 & 4 \\
\hline $\begin{array}{l}\text { Involvement } \\
\text { Average: }\end{array}$ & 4.33 & 3.83 \\
\hline $\begin{array}{l}\text { Prompt: My } \\
\text { math teacher... }\end{array}$ & & \\
\hline $\begin{array}{l}\text { believes I can do } \\
\text { good work. }\end{array}$ & 5 & 3 \\
\hline $\begin{array}{l}\text { explains Math } \\
\text { in ways that I can } \\
\text { understand }\end{array}$ & 5 & 3 \\
\hline $\begin{array}{c}\text { is inconsistent } \\
\text { with expectations }\end{array}$ & 1 & 3 \\
\hline $\begin{array}{l}\text { isn't available } \\
\text { for help when I } \\
\text { need it }\end{array}$ & 4 & 4 \\
\hline $\begin{array}{l}\text { shows me how } \\
\text { to solve problems } \\
\text { for myself. }\end{array}$ & 5 & 2 \\
\hline $\begin{array}{l}\text { doesn't make it } \\
\text { clear what he/she } \\
\text { expects of me. }\end{array}$ & 4 & 3 \\
\hline $\begin{array}{l}\text { Structure } \\
\text { Average: }\end{array}$ & 4.00 & 3.00 \\
\hline $\begin{array}{l}\text { listens to my } \\
\text { ideas. }\end{array}$ & 5 & 3 \\
\hline
\end{tabular}

\begin{tabular}{|c|c|c|}
\hline $\begin{array}{l}\text { My Science Teacher } \\
\text { doesn't understand me. }\end{array}$ & 4 & 5 \\
\hline $\begin{array}{l}\text { My Science Teacher } \\
\text { doesn't even know who I } \\
\text { am }\end{array}$ & 4 & 3 \\
\hline $\begin{array}{l}\text { My Science Teacher } \\
\text { really cares about me. }\end{array}$ & 4 & 4 \\
\hline $\begin{array}{l}\text { My Science Teacher is } \\
\text { never there for me. }\end{array}$ & 4 & 4 \\
\hline & 4.00 & 4.33 \\
\hline $\begin{array}{l}\text { Prompt: My science } \\
\text { teacher... }\end{array}$ & & \\
\hline $\begin{array}{l}\text { believes I can do good } \\
\text { work. }\end{array}$ & 5 & 5 \\
\hline $\begin{array}{l}\text { explains Science in } \\
\text { ways that I can } \\
\text { understand }\end{array}$ & 5 & 5 \\
\hline $\begin{array}{l}\text { is inconsistent with } \\
\text { expectations }\end{array}$ & 4 & 3 \\
\hline $\begin{array}{l}\text { isn't available for help } \\
\text { when I need it }\end{array}$ & 4 & 4 \\
\hline $\begin{array}{l}\text { shows me how to solve } \\
\text { problems for myself. }\end{array}$ & 5 & 1 \\
\hline $\begin{array}{l}\text { doesn't make it clear } \\
\text { what he/she expects of } \\
\text { me. }\end{array}$ & 4 & 4 \\
\hline & 4.50 & 3.67 \\
\hline listens to my ideas. & 5 & 1 \\
\hline
\end{tabular}




\begin{tabular}{|c|c|c|}
\hline $\begin{array}{l}\text { explains why } \\
\text { Math is } \\
\text { important. }\end{array}$ & 4 & 2 \\
\hline \begin{tabular}{l}
\multicolumn{1}{l}{ is always } \\
getting on my \\
case about \\
schoolwork.
\end{tabular} & 4 & 4 \\
\hline $\begin{array}{l}\text { Autonomy } \\
\text { Support } \\
\text { Average: }\end{array}$ & 4.33 & 3.00 \\
\hline $\begin{array}{l}\text { loves teaching } \\
\text { me about Math. }\end{array}$ & 5 & 1 \\
\hline $\begin{array}{l}\text { thinks that } \\
\text { Math is } \\
\text { interesting and } \\
\text { important. }\end{array}$ & 5 & 3 \\
\hline $\begin{array}{l}\text { Teacher } \\
\text { Engagement } \\
\text { Average: }\end{array}$ & 5 & 2 \\
\hline $\begin{array}{l}\text { We are learning } \\
\text { important things } \\
\text { in Math. }\end{array}$ & 3 & 3 \\
\hline $\begin{array}{l}\text { Our projects in } \\
\text { Math are } \\
\text { interesting and } \\
\text { fun. }\end{array}$ & 3 & 3 \\
\hline $\begin{array}{l}\text { All the work we } \\
\text { do in Math is } \\
\text { worth the effort. }\end{array}$ & 3 & 3 \\
\hline $\begin{array}{l}\text { The stuff we } \\
\text { learn in Math is } \\
\text { connected to the } \\
\text { real world of } \\
\text { Math. }\end{array}$ & 2 & 3 \\
\hline $\begin{array}{l}\text { Curriculum } \\
\text { specific: } \\
\text { Authentic } \\
\text { Academic Work } \\
\text { Average: }\end{array}$ & 2.75 & 3 \\
\hline
\end{tabular}

\begin{tabular}{|c|c|c|}
\hline $\begin{array}{l}\text { explains why Science } \\
\text { is important. }\end{array}$ & 5 & 1 \\
\hline $\begin{array}{l}\text { is always getting on } \\
\text { my case about } \\
\text { schoolwork. }\end{array}$ & 3 & 4 \\
\hline & 4.33 & 2.00 \\
\hline $\begin{array}{l}\text { loves teaching me } \\
\text { about Science. }\end{array}$ & 5 & 5 \\
\hline $\begin{array}{l}\text { thinks that Science is } \\
\text { interesting and important. }\end{array}$ & 5 & 5 \\
\hline & 5 & 5 \\
\hline $\begin{array}{l}\text { We are learning } \\
\text { important things in } \\
\text { Science. }\end{array}$ & 5 & 2 \\
\hline $\begin{array}{l}\text { Our projects in Science } \\
\text { are interesting and fun. }\end{array}$ & 5 & 3 \\
\hline $\begin{array}{l}\text { All the work we do in } \\
\text { Science is worth the } \\
\text { effort. }\end{array}$ & 4 & 1 \\
\hline $\begin{array}{l}\text { The stuff we learn in } \\
\text { Science is connected to } \\
\text { the real world of Science. }\end{array}$ & 5 & 4 \\
\hline & 4.75 & 2.5 \\
\hline
\end{tabular}




\begin{tabular}{|l|r|r|}
\hline $\begin{array}{l}\text { Feedback is } \\
\text { instructive and } \\
\text { helpful. }\end{array}$ & 5 & 2 \\
\hline $\begin{array}{l}\text { Communications } \\
\text { are friendly, so I } \\
\text { know I can ask } \\
\text { him/her questions } \\
\text { any time. }\end{array}$ & & \\
\hline $\begin{array}{l}\text { Grading is too } \\
\text { slow. }\end{array}$ & 5 & 3 \\
\hline $\begin{array}{l}\text { Response time } \\
\text { to questions is too } \\
\text { slow. }\end{array}$ & 3 & \\
\hline & & \\
$\begin{array}{l}\text { Communications } \\
\text { seem bossy and } \\
\text { condescending } \\
\text { (too "teacher"y). }\end{array}$ & & \\
\hline $\begin{array}{l}\text { Communications } \\
\text { Average: }\end{array}$ & & \\
\hline
\end{tabular}

\begin{tabular}{|l|r|r|}
\hline $\begin{array}{l}\text { Feedback is instructive } \\
\text { and helpful. }\end{array}$ & 5 & \\
\hline $\begin{array}{c}\text { Communications are } \\
\text { friendly, so I know I can } \\
\text { ask him/her questions any } \\
\text { time. }\end{array}$ & & \\
\hline & 5 & \\
$\begin{array}{c}\text { Grading is too slow. } \\
\text { Response time to }\end{array}$ & 4 & \\
\hline questions is too slow. & & \\
\hline & & \\
\hline $\begin{array}{c}\text { Communications seem } \\
\text { bossy and condescending } \\
\text { (too "teacher"y). }\end{array}$ & & \\
\hline & & \\
\hline
\end{tabular}




\title{
Appendix C: Human Rights Subject Approval
}

\author{
P Portland State \\ Post Office Box $751 \quad 503-725-2227$ tel \\ Portland, Oregon 97207-0751 503-725-8170 fax \\ Human Subjects Research Review Committee \\ hsrrciglists.pdx.edu \\ Date: Apnl 30, 2015 \\ To: Melissa Potter / Scott Barrentine \\ From Karen Cellarius, HSRRC Chair

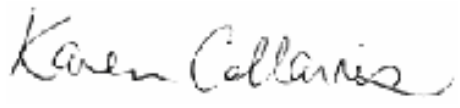 \\ Re: HSRRC approval for your project tifled, "Ranking Motivational Factors in an Online STEM Environment" \\ HSRRC Proposal \# 153360
}

Approval-Expiration: Apnl 30, 2015-Aprl 29, 2016

Review Type: Expedited, Categories 7

In accordance with your request, the PSU Human Subjects Research Review Committee has reviewed your request for approval of the project referenced above for compliance with PSU and DHHS policies and regulations covering the protection of human subjects. The Committee is satisfied that your provisions for protecting the rights and welfare of all subjects participating in the research are adequate, and your project is approved. Please note the following requirements:

Approval: You are approved to conduct this research study only during the period of approval cited above; and the research must be conducted according to the plans and protocol submitted (approved copy enclosed).

Consent: Signed consent is required from all participants in this study.

Changes to Protocol: Any changes in the proposed study, whether to procedures, survey instruments, consent forms or cover letters, must be outlined and submitted to the Committee immediately. The proposed changes cannot be implemented before they have been reviewed and approved by the Committee.

Continuing Review: This approval will expire on 04/29/2016. It is the investigator's responsibility to ensure that a Continuing Review Report on the status of the project is submitted to the HSRRC two months before the expiration date, and that approval of the study is kept current. The IRB offices does not send out notifications of expiration dates. The Continumg Roview Repport is available at www.rsp.pdx.edu/compliance_human.php and in the Office of Research and Strategic Partnerships (RSP).

Adverse Reactions and/or Unanticipated Problems: If any adverse reactions or unanticipated problems occur as a result of this study, you are required to notify the Committee immediately. If the issue is serious, approval may be withdrawn pending an investigation by the Committee.

Completion of Study: Please notify the Committee as soon as your research has been completed. Study records, including protocols and signed consent forms for each participant, must be kept by the investigator in a secure location for three years following completion of the study (or per any requirements specified by the project's funding agency).

If you have questions or concerns, please contact the Office of Research Integrity in the PSU RSP at 503-725-2227. 


\title{
蛋 Portland State
}

\author{
Post Office Box $751 \quad 503-725-2227$ tel \\ Portland, Oregon 97207-0751 503-725-8170 fax \\ Human Subjects Research Review Committee \\ hsrrcilists.pdx.edu
}

Date: June 11, 2015

To: Melissa Potter / Scott Barrentine

From: Karen Cellarius, HSRRC Chair

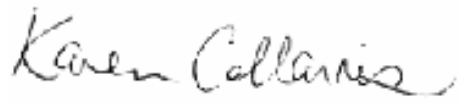

Re: HSRRC approval for your project \# 153360, entitled, "Ranking Motivational Factors in an Online STEM Environment"

Approval-Expiration: June 11, 2015 - April 29, 2016

\section{Notice of IRB Review and Approval-Amendment Expedited Review as per Title 45 CFR Part 46.110, 63 FR 60366, \# 7}

The amendment submitted on 06/09/2015 for the project identified above has been reviewed and approved by the Portland State University Institutional Review Board (IRB) and the Office of Research Integity using an expedited review procedure. This is a minimal risk study. This approval is based on the assumption that the materials, including changes/clarifications that you submitted to the IRB contain a complete and accurate description of all the ways in which human subjects are involved in your research.

This approval is given with the following standard conditions:

1. You are approved to conduct this research only during the period of approval cited below,

2. You will conduct the research according to the plans and protocol submitted (approved copy enclosed);

3. You will immediately inform the Office of Research Integrity of any injuries or adverse research events involving subjects;

4. You will immediately request approval from the IRB of any proposed changes in your research, and you will not initiate any changes until they have been reviewed and approved by the IRB;

5. You will only use the approved informed consent document(s) (enclosed);

6. You will give each research subject a copy of the informed consent document,

7. If your research is anticipated to continue beyond the IRB approval dates, you must submit a Continuing Review Request to the IRB approximately 60 days prior to the IRB approval expiration date. Without continuing approval the Protocol will automatically expire on 04/29/2016.

Portland State University and the Office of Research Compliance appreciate your efforts to conduct research in compliance with PSU Policy and the Federal regulations that have been established to ensure the protection of human subjects in research. Thank you for your cooperation with the IRB process.

If you have questions or concerns, please contact the Office of Research Integrity at 503-725-2227.

Approved: Student Assent Form and Survey version 06/09/2015;

Student Survey of Teacher Practices and Relationships version 06/09/2015. 


\title{
象 Portland State
}

\author{
Post Office Box 751 \\ Portland, Oregon 97207-0751 503-725-8170 fax \\ Human Subjects Research Review Committee \\ hsrro@pdx.edu
}

Date: Jume 20, 2016

To: Melissa Potter and Scott Barrentine

From: Karen Cellarius, HSRRC Chair

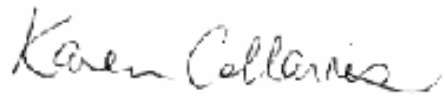

$\operatorname{Re}$ HSRRC approval of closure for your project titled, "Ranking Motivational Factors in an Online STEM Environment" HSRRC Proposal \#153360

In accordance with your request, the PSU Human Subjects Research Review Committee has reviewed your request for closure of the project referenced above for compliance with PSU and DHHS policies and regulations covering the protection of human subjects. The Committee is satisfied that your provisions for protecting the data of all subjects participating in the research are adequate, and your project is closed.

If you have questions or concerns, please contact the Office of Research Integrity in the PSU RSP at 503-725-2227. 